UNIVERSIDADE DE SÃO PAULO

INSTITUTO DE QUIMICA

\title{
ESTUDO SOBRE A EXTRAÇÃO DO MOLIBDÉNIO(VI) EM SOLVENTES ORGÂNICOS E SUA APLICAÇÃO ANALITICA
}

Orientador:

Prof. Dr. Paschoal Senise

UNIVERSIDADE DE SAO. PAULO

BIBLIOTECA CENTRAL

CQ/1C-4

Tese de Doutoramento

ANA ROSA KUCINSKI 
Agradecimentos

Ao Professor Dr. Paschoal Senise, sob cuja orientação foi elaborado o presente trabalho.

Aos colegas e funcionärios da Quimica Analitica que, de di ferentes maneiras colaboram na sua execução.

Ao Conselho Nacional de Pesquisa e à Fundação de Amparo à Pesquisa do Estado de São Paulo, pelo auxilio material. 
Ao meu pai 
INDICE

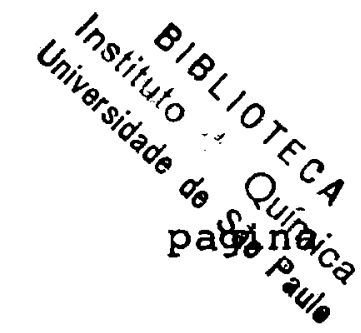

I - INTRODUÇÃO

1 - Principais métodos colorimētricos para determi nação de molibdênio ..................... 8

2 - Emprego de derivados da fluorona $(2,3,7$-trihidroxi-6-fluorona) e determinação do molibdênio em meio orgânico $\ldots \ldots \ldots \ldots \ldots \ldots \ldots \ldots \ldots \ldots \ldots$

II - ESTUDOS PRELIMINARES

1 - Considerações gerais ..................... 21 .

2 - Estudo comparativo da extratibilidade do Mo(VI) e do $W(V I)$ de soluções clorídricas ........... 22

3 - Estudo qualitativo da extração do Mo(VI) ........ 30

4 - Estudo quantitativo da extração do Mo(VI) ....... 32

5 - Coeficiente de extração ................... 34

6 - Considerações sobre a espēcie extzaída ........ 35

7 - Procedimento para a extração ............... 36

III - ELABORAÇÃO DO METODO ANALITICO .............. 37

1 - Considerações gerais - preparo da solução do

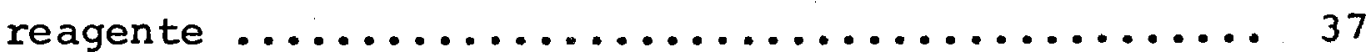

2 - Estudo da reação molibdênio(VI)-fenilfluorona em meio orgânico .................... 38

3 - Influência do volume do reagente ............. 41

4 - Influência do nümero de extraçīes ............. 44

5 - Efeito da variação do solvente adicionado ao extrato orgânico apōs a reaçãc colorimétrica .... 46 
6 - Eficiência da extração - Reversão à fase aquosa .............................

7 - Estatibilidade da cor

8 - Proporcionalidade dos valores - Lei de Lambert-Beer ........................... 52

9 - Região de concentração favorāvel - grāfico de Ringbom ........................... 52

10- Estudo dá precisão do método .............. 55

11- Absortividade molar ................... 57

$12-$ Procedimento analítico $\ldots \ldots \ldots \ldots \ldots \ldots \ldots \ldots \ldots$

13- Estudo das interferēncias ................ 59

13.a - Estudo geral .................. 59

$13 . b$ - Eliminação das interferências de ferro(III) e Vanādio(VI) ........... 64

IV - ESTUdO DA SEPARAÇÃO MOLIBDENIO-TUNGSTENIO . . . . . . 66

1 - Considerações gerais ..................... 66

2 - Estudo da extratibilidade do Mo(VI) e W(VI) com os sais de fosfônio: brometo de trifenil n-butil fosfônio e brometo de trifenil iso-butil fosfônio .......................... 69

3 - Estudo da extratibilidade do Mo(VI) e W(VI) no sistema clorídrico e sulfúrico ............... 79

4 - Influência do ácido cítrico na extratibilidade do $M o(V I)$ e $W(V I) \ldots \ldots \ldots \ldots \ldots \ldots \ldots \ldots . \ldots \ldots . \ldots . . \ldots$

5 - Influência do ácido cítrico nas reações de Mo(VI) e W(VI) com fenilfluorona em meio orgânico

6 - Determinação de Mo(VI) na presença de W(VI) em meio orgânico contendo ácido cítrico............ 
I - Preparação do composto molibdênio(VI)-fenilfluo

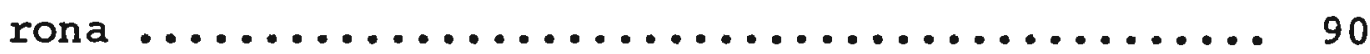

2 - Estudo da solubilidade do composto ............. 91

3 - Estudo comparativo dos espectros em melo orgânico .............................. 98

4 - Características fluorescentes das soluções de fenilfluorona e do composto molibdênio(VI)-fenilfluorona em meio orgânico............... 101

5 - Composição do complexo - estudo em meio orgâ-

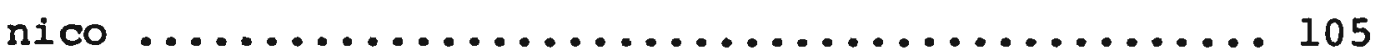

5. a - Método das variações contínuas ....... 105

$5 . b$ - Método da razão molar .............. 106

6 - Algumas características do composto molibdênio(VI)-fenilfluorona no estado sölido ......... 110

6.a - Espectro de reflectância ........... 110

$6 . b$ - Espectro eletrōnico no visivel ....... 112

7 - Teor de molibdênio no composto ............... 112

VI - APLICAÇÃO DO METODO ...................... 114

VII - ESTUDO POLAROGRAFICO ................... 115

1 - Considerações gerais ...................... 115

2 - Influência do $W(V I)$ na onda catalitica do

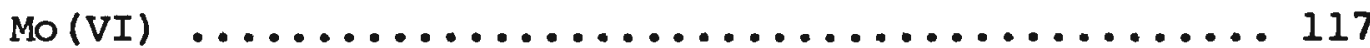

3 - Curvas de calibração ...................... 120

VIII - CONSIDERAÇס̃ES FINAIS ................... 126 
IX - DETALHES EXPERIMENTAIS .................... 129

1 - Aparelhagem .......................... 129

2 - Solventes e reagentes .................... 131

3 - Solução padrão de molibdênio(VI) ............. 132

4 - Soluções usadas no estudo das interferências .... 132

5 - Tratamento inicial da amostra. Eliminação de $\mathrm{Ge}(\mathrm{IV}), \mathrm{C}_{2} \mathrm{O}_{4}^{-2}, \mathrm{MnO}_{4}^{-}$e $\mathrm{Cr}_{2} \mathrm{O}_{7}^{-2} \ldots \ldots \ldots \ldots \ldots \ldots$

6 - Sais de fosfônio ....................... 134

7 - Destruição do complexo molibdênio(VI)-fenil-

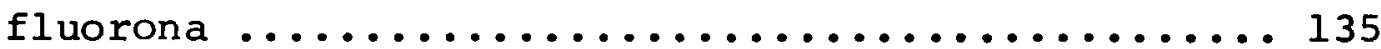

8 - Detalhes referentes aos estudos polarogrä́ficos ... 135

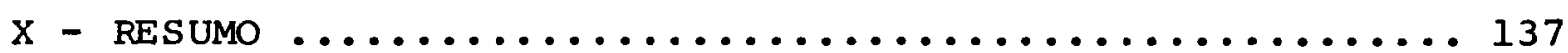

XI - BIBLIOGRAFIA .......................... 139 


\section{I - INTRODUCÅO}

1) PRINCIPAIS METODOS COLORIMETRICOS PARA DETERMINAÇÃO DE MOLIBDENIO.

A separação e determinação do molibdênio em escala micro-analítica constituiu-se por muito tempo num problema analitico que os pesquisadores não consideravam satisfatōriamente resolvido, tendo-se em vista principalmente a enorme importância de sua determinação nos mais di versos tipos de materiais. Efetivamente, o molibdênio está presente em materiais biológicos (sangue e plantas) em solos, ăguas naturais, minérios de tungstênio e como componente de aços e ligas especiais.

A necessidade de encontrar melos mais precisos e eficientes de determinação fez com que a pesquisa se desenvolvesse no sentido de aperfeiçoar os primeiros métodos conhecidos e também encontrar novos processos baseados em reações de maior seletividade e espectficidade.

Um exame atento da literatura revela que são numerosos os mētodos de determinação do molibdênio e que predominam sobre os demais os mētodos colorimētricos e espectrofotométricos. Isto se deve ao fato de não só possibi litarem maior simplicidade nas tëcnicas de trabalho como 
tambēm permitirem determinações de baixos teores do elemen to devido a elevada sensibilidade de certas reações.

Por outro lado, a utilização dos princípios de extração com solventes, com fins analíticos, encontrou vasto campo de aplicação na determinação do molibdênio. A. I.Busev ${ }^{(1)}$ assinala em recente publicação, enormes progressos neste setor.

Sandell ${ }^{(2)}$ destaca os primeiros métodos de separação e determinação do molibdênio. Observa-se em sua obra que sòmente a partir de 1935 é que a pesquisa neste setor passou a se desenvolver mais intensamente.

o primeiro grupo de mētodos de determinação do molibdênio baseia-se na sua reação em meio ãcido, com Ions tiocianato na presença de redutores como cloreto de estanho. Nesta reação forma-se un complexo vermelho que permite uma determinação colorimētrica bastante sensível.

- são muitos os fatores que influem sobre a reação. A intensidade da coloração que se obtem depende sensivelmente da acidez, da concentração de íons tiocianato e do tempo de repouso da solução. A estabilidade da cor é função crítica da maior ou menor acidez; apenas o cloreto de estanho é fá tor menos importante na reação.

Assim, nos primeiros trabalhos baseados nesta reação procurou-se estudar estes fatores e encontrar condições que permitissem um aproveitamento analitico eficiente. 
Loren C. Hurd e Harry O. Allen (3), em 1935, estabeleceram algumas condições experimentais que possibilitaram a elaboração de um método de determinação e procuraram ainda extrair o complexo por meio de solventes eter etílico, acetato de n-butila e ciclohexanol sem entre tanto alcançar bons resultados. Em 1940, C.F. Hiskey e V.W. Meloche ${ }^{(4)}$ estudaram a natureza do composto formado e A.K. Babko ${ }^{(5)}$ em 1947 estabeleceu as vārias espēcles que se for mam na reação do molibdênio reduzido com íons tiocianato. A espēcie de coloração mais intensa (vermelha) tem a fórmu la Mo(CNS) $5^{\text {. }}$

Em 1943 F.S. Grimaldi e R.C. Wells ${ }^{(6)}$ analisaram o molibdênio em minērios de tungstênio utilizando o método do tiocianato-cloreto de estanho, sòmente que adicionaram citrato de potássio à solução para evitar idêntica reação com o tungstênio. Tentaram também obter maior es tabilidade da cor adicionando acentona à solução. Entretan to, em 1945, Mitchell Kapron e Paul Hechman (7) utilizando eter glicölico, metilicarbitol e solosolve, miscíveis em água, alcançaram maior estabilidade.

Em 1958 A.I. Lazarev ${ }^{(8)}$ substituiu o cloreto de estanho pelo ácido ascórbico na redução do molibdênio e Inibiu a reação do tungstênio adicionando ácido cítrico. Lebedeva e Potrokhov ${ }^{(9)}$ utilizzaram ācido ascōrbico para im pedir a reação de tlocianato com o tungstênio. 
contradas para solucionar os problemas devidos às interfé. rências e à estabilidade das soluções, alguns pesquisadores procuraram explorar a reação molibdênio(V) - tiocianato por meio da extração do elemento e posterior desenvolvimen to da cor ou pela extração direta do complexo formado em meio aquoso com solventes apropriados.

Loren H. Hund e Harry O. Allen (3) já haviam tentado algum resultado neste sentido.

Perrin (10) utilizou álcool iso-amilico para extrair o complexo de molibdềnio(V)-tiocianato. Estabeleceu novas condições de acidez e de concentração dos reagen tes obtendo maior estabilidade da cor. Fez a determinação no prōprio extrato orgânico e permitiu maior tolerância com relação a íons interferentes.

Em 1962 J.O. Hibbitz e R.T. Williams ${ }^{(11)}$ extrairam o complexo com metil-isobutil-cetona alcançando maior sensibilidade; entretanto vārios ions interferiram na determinação.

Ainda assinalam-se alguns trabalhos de extra ção do complexo do melo aquoso com diferentes solventes $(12-14)$.

Com relação à extração prēvia do molibdênio e a subsequente determinação com tiocianato, destacam-se os trabalhos de Dhara(15), Takaoshi Yoshinori (16), Ping e 
Sandel $1^{(17)}$ e James P. Mc.Kaverney ${ }^{(18)}$.

Efetivamente, um exame detalhado destes trabalhos mostrou que tanto as determinações em meio aquoso quanto as determinações feitas apōs a extração do complexo exigem uma separação prēvia do elemento por extração com eter etilico, $\alpha$-benzoinoxima ou cupferron, seguindo-se uma reversão ao meio aquoso. Este processo torna-se necessārio a fim de se obter maior seletividade com relação à presença de outros elementos no material.

Outro grupo de métodos de determinação de mo libdênio é encontrado na literatura e se refere ao aprovei tamento analítico da reação dêste elemento com Ditiol (4-metil - 1,2 mescaptobenzeno).

Hamence ${ }^{(19)}$ foi o primeiro pesquisador a observar em 1940 a coloração amarela-esverdeada que o ditiol fornecia em soluções ãcidas com o molibdênio(VI). Em 1948 Brickford e colaboradores ${ }^{(20)}$ extrairam o complexo molibdênio-ditiol em acetato de n-butila e utilizaram a coloração amarelo-esverdeada numa determinação bastante sensível. Neste método os metals pesados foram removidos por uma extração prévia com ditizona e a reação semelhante que - tungstênio dá com o reagente foi inibida pela presença de ãcido citrico.

$$
\text { Piper e R.S. Beckewith (21), neste mesmo ano, }
$$
determinam o molibdênio em plantas pela extração do comple 
xo de ditiol com acetato de amila. Embora o molibdênio seja separado prēviamente pela sua extração com cupferron em clorofórmio, o método não oferece tolerância com relação à presença de outros elementos.

Em 1952, S.H. Allen e M.B. Hamilton (22) esta beleceram um mētodo que permite determinar ambos, molibdênio(VI)e tungstênio(VI) com ditiol. Inicialmente se removem outros ions por meio de uma extração dos seus ditizonatos; segue-se uma precipitação do molibdênio e do tungstênio com cupferron e sua extração com álcool isoamílico. Em seguida à destruição dos complexos, desenvolve-se a cor do molibdênio-ditiol em acidez elevada e extrai-se com eter de petróleo. o tungstênio(VI) è determinado em meio aquoso com o mesmo reagente. O molibdênio(VI) é determinado na presença de cem vezes seu teor com relação ao tungstênio(VI) .

Jeffery ${ }^{(23)}$ aperfeiçoou o método anterior ex traindo os dois complexos separadamente, pelo condicionamento apropriado do meio, com eter etílico. Estes elementos foram isolados de outros por uma extração prévia com $\alpha$-benzoinoxima em clorofórmio.

En 1962 Everett Hobart e E.P. Hurley ${ }^{(24)}$ extraíram o complexo de molibdênio-ditiol com tetracloreto de carbono depois de reduzir o tungstênio. Em seguida este é complexado com o reagente e extraído com o mesmo solvente. 
Estes trabalhos são os de maior importāncia dentre vários outros existentes na literatura baseados na reação de molibdênio com ditiol.

Um terceiro grupo de mētodos colorimétricos na determinação do molibdênio se destaca da literatura. Trata-se do aproveitamento analitico de reações que este elemento desenvolve com o pirocatecol e alguns de seus derivados, notadamente o "Tiron" (1,2, - dihidroxibenzeno, 3,5 - dissulfonato de sōdio) (25-30).

A reação de molibdênio com pirocatecol jã ē conhecida de há muito (1932). Entretanto, sōmente em 1951 s. Selfter e B. Novic ${ }^{(25)}$ utilizaram-na para determinar o elemento. M. Shapiro ${ }^{(27)}$ obteve maior sensibilidade com o pirocatecolaldeído e G.P. Haight e colaboradores ${ }^{(26)}$ verificaram a dependência entre o pH e a formação dos complexos procurando estabelecer as fórmulas dos mesmos.

Em 1952, John H. Yoo e Fritz Will ${ }^{(28)}$ observaram que o molibdênio formava complexo amarelo, estável com o "Tiron" e utilizaram esta reação na elaboração de um método de determinação ${ }^{(29)}$. Entretanto o método é pouco se letivo e de menor sensibilidade do que aqueles baseados na reação com tiocianato ou ditiol. o molibdênio deve ser separado prèviamente com $\alpha$-benzoinoxima sendo que o tungstênio constitui sērie interferência.

Em 1953 Fritz Will e John Yoe ${ }^{(31)}$ estabelece 
ram um método de determinação do molibdênio, na presença de grandes quantidades de ferro, baseado na reação com ācl do mercaptoacético. Inúmeros elementos interferiram, inclu sive tungstênio, vanádio, titânio e zircônio. Dumas A. Otterson e J.W. Graab ${ }^{(32)}$ aperfeiçoaram o método procedendo a uma extração prévia do molibdênto com $\alpha$-benzoinoxima e ut1lizando o ácıdo citrico para evitar a reação do tungstênio, nióbio, tântalo, zircônio e titânio com o reagente.

A quercetina e a dihidroquercetina foram ut 1 lizadas por F. Chan e R.W. Moshier ${ }^{(33)}$ e G. Goldstein e co laboradores ${ }^{(34)}$ como reagentes colorimétricos para o molib dênio (coloração amarela). Este foi separado por sua extrạ ção prévia com $\alpha$-benzolnoxima e a cor do complexo desenvol vida após reversão ou na própria solução orgânica contendo a oxima. Entretanto, alguns ions constituiram sērias inter ferências.

Encontram-se tambēm alguns trabalhos que uti lizam a reação de molibdênio com 8-hidroxiquinolina ou 8-mercaptoquinolina $(35-37)$. Os complexos formados em meio aquoso são extraídos com solventes e determinados na fase orgânica. Apesar da sensibilidade elevada dessas reações, vărios elementos também reagem com o complexante comprometendo a seletividade dos métodos.

Assinala-se finalmente 0 trabalho de Glenn R. Waterbury e C.E. Bricker ${ }^{(38)}$ em que o molibdênio è extraído de soluções cloríaricas com metil-isobutil-cetona, 
revertido à fase aquosa e determinado com ácido cloranilico. O método é extremamente moroso e não apresenta pràtica mente nenhuma seletividade.

2) EMPREGO DE DERIVADOS DA FLUORONA E DETERMINAÇÃO DO MOLIBDENIO EM MEIO ORGÁNICO.

Em 1947 Gillis e colaboradores $(39,40)$ fizeram um estudo comparativo das propriedades analiticas de alguns derivados da fluorona $(2,3,7$ - trihidroxi-6-fluorona), com diversos elementos e elaboraram duas provas de to que bastante sensíveis e especificas utilizando a o-oxi-fe nilfluorona $(2,3,7$ - trihidroxi-9-(o-oxi-fenil)-6-fluorona) para o molibdênio e a fenilfluorona $(2,3,7$ - trihidroxi-9-fenil-6-fluorona) para o germânio.

Posteriormente foram publicados alguns traba Ihos de determinação espectrofotomētrica de germânio, zircônio, titânio, estanho, antimônio e molibdênio em que tan to a fenilfluorona quanto outros derivados da fluorona, es pecialmente a 9-metil-2,3,7-trihidroxi-6-fluorona, eram ut lizados como reagentes altamente sensiveis ${ }^{(41-49)}$. Os produtos destas reações são precipitados que na maioria dos casos resistem a ácidos e, para possibilitar as medidas co lorimētricas, são mantidos em suspensão por meio de goma arābica ou gelatina. A reprodutividade dos resultados de- 
pende do condicionamento do meio pelo controle do $\mathrm{pH}$ e do tempo de desenvolvimento da cor.

Um exame minucioso destes trabalhos mostrou que efetivamente a fenilfluorona e alguns derivados dá fluorona oferecem extraordināria sensibilidade, a ponto de se poder determinar os elementos em teores balxíssimos, da ordem de décimos de microgramas. Entretanto, além de apresentarem alguns problemas relacionados com a estabilidade das soluções aquosas, trata-se de reagentes que abrangem tniin um grupo de elementos: germânio, molibdênio, titânio, estanho, antimônio, zircônio, vanádio e outros. com isto, estes métodos apresentam, em cada caso, sērias limitações devidas às interferências dos outros elementos.

Com o sentido de alcançar maior seletividade nas determinações do germânio, alguns pesquisadores valeram-se da separação prévia por extração do elemento ${ }^{(50-52)}$ mas necessitaram revertê-lo à fase aquosa para posterior desenvolvimento da cor, persistindo os inconvenientes que disso advem.

Kenjiro Kimura (53), em 1956, Hirotoshi Sano(54) em 1958 e M.B. Shustova e V.A. Nazarenko ${ }^{(55)}$ prepararam vārios outros derivados da fluorona e estudaram suas reações com diversos elementos, principalmente germânio e molibdênio. 
Em 1960, Majundar e Savariar ${ }^{(48)}$ elaboraram um mëtodo de determinação de molibdênio em meio aquoso com a 9-metil-2,3,7-trihidroxi-6-fluorona. Neste artigo os autores não estudaram a influência, sôbre a determinação, da presença dos vārios íons que também reagem com complexantes deste tipo, segundo cluley ${ }^{(4 I)}$ e outros pesquisadores jā haviam indicado em seus trabalhos. Apenas mencionam que a os Ions de titânio, zircônio e tungstênio são tolerados quando presentes em quantidades inferiores a do molibdênio.

Num pequeno estudo para ânions apresentado neste trabalho(pg 162) verificou-se pelo exame dos resulta dos que os ions fluoreto, fosfato e oxalato são tolerados apenas quando presentes em concentrações inferiores a cinco vezes a concentração do molibdênio e os íons de ferro(III), uranila e alumínio podem estar presentes em concen trações até vinte e cinco vezes a do molibdênio.

Em 1959, P. Senise e Iilia Sant'Agostino(56) elaboraram um mētodo de determinação do germânio após sua extração, a partir de soluções fortemente ācidas, com metil-isobutil-cetona e fizeram a determinação no próprio ex trato orgânico pela adição da fenilfluorona. Obtiveram excelente reprodutividade e estabilidade da solução e ainda aumento da sensibilidade do mētodo com relação aos anterio res. Neste trabalho, desenvolvido em nosso laboratōrio, o molibdênio, tungstênio, nióbio e outros elementos constituiram sērias interferências por reagirem igualmente com a fenilfluorona em meio orgânico. Foi necessärio um tratamen 
to preliminar com cupferron para separā-los.

A partir destes estudos, pensou-se em utilizar a fenilfluorona como reagente colorimétrico na determi nação do molibdênio após sua extração do meio aquoso em um mētodo que oferece sensíveis vantagens com relação aos já existentes.

Efetivamente, uma determinação desse tipo ofereceria de início a enorme vantagem de não ser necessária uma separação prēvia do elemento por meio de sua extra ção com $\alpha$-benzoinoxima. De fato, esta separação se faz necessāria invariāvelmente para a grande maioria dos métodos conhecidos, inclusive naqueles em que 0 molibdênio após a reversão à fase aquosa sofre nova extração, quer na forma de um quelato, quer como espécie neutra para subsequente determinação.

O uso de meio orgânico para o desenvolvimento da cor e a determinação espectrofotométrica direta, eli minam a necessidade de um controle rigoroso do pH, que é uma condição comumente encontrada nos sistemas aquosos e nos quais a fenilfluorona se inclui.

Busev (I) assinala que as determinações desse tipo apresentam as vantagens de aumentar a seletividade, evitar as perdas que normalmente ocorrem nos processos de reversão à fase aquosa e finalmente torna-as mais rāpidas e eficientes. 
Como consequência do acima exposto, procurou-se elaborar um mētodo de determinação do molibdênio(VI) em meio orgânico por sua extração prévia mediante o emprêgo de um solvente apropriado que possibilitasse um perfeito desenvolvimento da cor do complexo com fenilfluorona. Procurou-se, tambēm, tornar êsse método o mais seletivo possivvel com relação ao molibdênio(VI) dando especial aten ção aos problemas provenientes da presença de ions interfe rentes tentando resolvêlos da melhor forma.

Tendo-se em vista a enorme importância que o tungstênio representa nas determinações do molibdênio, constituindo-se na maloria dos mētodos em um interferente de difícil eliminação, procurou-se destacar neste trabalho seu comportamento, em ensaios paralelos ao molibdênio, visando eventualmente a uma separação entre êles. E, com este propósito, desenvolveu-se em capítulo especial um amplo estudo sistemātico tentando encontrar condições de separação seletiva ou de determinação do molibdênio na presença de elevado teor de tungstênio, por melo de extração com solventes.

E, finalmente, fez-se um estudo do composto molibdênio-fenilfluorona a fim de se obter algumas informa ções quanto a sua natureza e seu comportamento em soluções orgânicas. 
1) CONSIDERAÇÕES GERAIS

A literatura indica que o molibdênio(VI) é extraído de soluções ãcidas, principalmente de sistemas ha logenidricos por meio de solventes oxigenados como alcoois, éteres, cetonas e ésteres ${ }^{(58,59)}$.

A parte preliminar deste trabalho consistiu em estudar a extratibilidade do molibdênio(VI) de soluções cloríaricas com solventes daquele tipo. Não se achou conve niente neste estudo utilizar outros sistemas halogenidricos principalmente porque a literatura se refere à baixa extratibilidade do elemento no sistema fluorídrico(58) e tambēm devido à difícil manipulação dos ācidos $\mathrm{HF}, \mathrm{HBr}$ e HI; estes dois últimos ácidos exigiriam um controle constante de suas soluções devido à facilidade de oxidação aos respectivos halogêneos.

Apesar dos primeiros estudos de extração do molibdênio(VI) terem sido realizados por meio de éteres (etilico e isopropílico) (2) não se julgou interessante incluI-los neste estudo tendo em vista que a grande volatili dade que apresentam não ser adequada ao trabalho analític. Alēm disso, sendo preocupação adotar uma tēcnica que 
permitisse não só usar volumes pequenos de amostra e de solvente como tambēm fosse bastante precisa, simples e rāpida, evitou-se usar solventes de maior densidade do que a āgua, o que obrigaria ao uso de funís de separação e, consequentemente, envolveria procedimento mais elaborado.

Assim, orientou-se os estudos no sentido de escolher um solvente que possibilitasse não só uma extracão quantitativa do elemento, como tambēm um desenvolvimen to da cor do complexo com a fenilfluorona passível de se utilizar na espectrofotometria. Procurou-se tambēm tornar esta extração o mais seletiva possível com relação ao tungstênio(VI), por ser este elemento o principal interferente nos mētodos usualmente empregados.

2) ESTUDO COMPARATIVO DA EXTRACTIBILIDADE DO MOLIBDENIO(VI) E DO TUNGSTENIO(VI) DE SOLUÇÕES CLORIDRICAS.

A parte experimental deste estudo preliminar consistiu em verificar, apenas do ponto de vista qualitati vo, quais os solventes que melhor extraíam o Mo(VI), pelos valores de absorbância das soluções, quando se fez reagir - extrato orgânico obtido, com a fenilfluorona. Paralelamen te se procurou observar o comportamento do W(VI) extraindo-o nas mesmas condições. 
O reagente empregado fol preparado segundo Indıcação de outros trabalhos $(39,56)$ em que o mesmo é util1zado na determinação de germânio em melo orgânico.

Com amostras independentes contendo $25 \mu \mathrm{g}$ de molibdênio(VI) e $6 \mathrm{~N}$ em HCI, foram feitas extrações com 29 solventes. Usou-se a proporção $1: 1$ de melo aquoso para sol vente. A fase orgânica, separada, adicionou-se 1 inl de solução alcoōlica-sulfūrica 0,028 de fenilfluorona e diluiuse a $10 \mathrm{ml}$ com alcool etíl1co.

Na tabela 1 apresentam-se os valores de absorbância das amostras, medidas contra um branco obtido da mesma manelra, no comprimento de onda de máxima absorção. 
TABELA 1

Extrabilidade de Mo(VI) de soluções $6 \mathrm{~N}$ em HCl. $25 \mu \mathrm{g}$ Mo (VI) presente

$1 \mathrm{ml}$ fase aquosa: $1 \mathrm{ml}$ fase orgânica reação com fentlfluorona

\begin{tabular}{|l|c|c|}
\hline solvenTE & A & $\lambda(\mathrm{nm})$ \\
\hline etil n-amil cetona & 0,525 & 504 \\
di(isobutil) cetona & 0,260 & 504 \\
metil n-hexil cetona & 0,699 & 504 \\
metil isobutil cetona & 0,770 & 502 \\
metil n-amil cetona & 0,629 & 502 \\
di(n-amil) cetona & 0,205 & 504 \\
metil isoamil cetona & 0,463 & 504 \\
etil 1soamil cetona & 0,585 & 504 \\
metil n-butil cetona & 1,000 & 504 \\
etil n-butil cetona & 1,097 & 502 \\
ciclohexanona & 1,260 & 504 \\
2-n-bitilciclohexanona & 1,301 & 502 \\
2-metilciclohexanona & 1,398 & 504 \\
2- propilciclohexanona & 1,125 & 504 \\
3-metilciclohexanona & 1,260 & 504 \\
acetato de n-pentila & 1,071 & 502 \\
acetato de iso-pentila & 1,260 & 504 \\
acetato de n-butila & 1,194 & 504 \\
acetato de iso-propila & 1,071 & 502 \\
4-metilciclohexanona & 0,939 & 502 \\
acetato de benzila & 1,046 & 504 \\
benzoato de etila & 0,959 & 502 \\
formiato de n-butila & 0,602 & 502 \\
formiato de isoamila & 0,939 & 502 \\
n-octoato de etila & 0,284 & 502 \\
ftalato de butila & 0,272 & 502 \\
formiato de isobutila & 504 \\
propionato de iso-amila & 0,495 & 502 \\
n-butirato de etila & 502 \\
\hline
\end{tabular}


O exame destes resultados indica que existem enormes diferenças na extrabilidade do Mo(VI) no sistema cloridrico para os diferentes solventes. Destes, selecionou-se aqueles que apresentaram maior extratibilidade reve lada pelos valores mais elevados de absorbância. Com èstes solventes elaborou-se nova sērie de extrações, para o $W(V I)$, segundo as mesmas condições em que foram feitas as extrações do Mo(VI).

Na tabela 2 reunimos estes solventes e compa ramos os valores de absorbância para os dois elementos.

Esta tabela permitiu concluir que, embora as absortividades molares dos complexos molibdênio(VI)-fenilfluorona e tungstênio(VI)-fenilfluorona em meio orgânico não sejam conhecidas, para os solventes em que a extratibi lidade do Mo(VI) foi mais acentuada o $W(V I)$ também foi extraído.

Passou-se a estudar, assim, a extratibilidade dêsses elementos em função da acidez. As extrações foram feitas em ensáios paralelos para os dois elementos varlando a acidez de $3 \mathrm{~N}$ a $6 \mathrm{~N}$ em $\mathrm{HCl}$, e utilizando aqueles solventes que em função da extratibilidade do Mo(VI) apresentaram os melhores resultados.

Os valores obtidos estão reunidos nos grăficos das figuras 1 e 2 . 


\section{TABELA 2}

Extratibilidade em solventes orgânicos de Mo(VI) e W(VI) de soluções $6 \mathrm{~N}$ em $\mathrm{HCl}$.

$25 \mu \mathrm{g}$ de Mo(VI) e W(VI) presentes

$1 \mathrm{ml}$ fase aquosa: $1 \mathrm{ml}$ fase orgânica reação com fenilfluorona

\begin{tabular}{|l|c|c|}
\hline \multirow{2}{*}{ SolvenTE } & \multicolumn{2}{|c|}{ A (504nm) } \\
\cline { 2 - 3 } metil n-butil cetona & Mo(VI) & W(VI) \\
etil n-but1l cetona & 1,000 & 0,420 \\
ciclohexanona & 1,097 & 0,083 \\
2 metil ciclohexanona & 1,260 & 0,409 \\
2 propil ciclohexanona & 1,398 & 0,561 \\
2 butil ciclohexanona & 1,125 & 0,276 \\
3 metil ciclohexanona & 1,301 & 0,218 \\
acetato de n-amila & 1,260 & 0,523 \\
acetato de iso-amila & 1,071 & 0,036 \\
acetato de n-butila & 1,260 & 0,076 \\
acetato de isopropila & 1,194 & 0,063 \\
acetato de n-propila & 1,071 & 0,149 \\
acetato de benzila & 1,046 & 0,208 \\
\hline
\end{tabular}




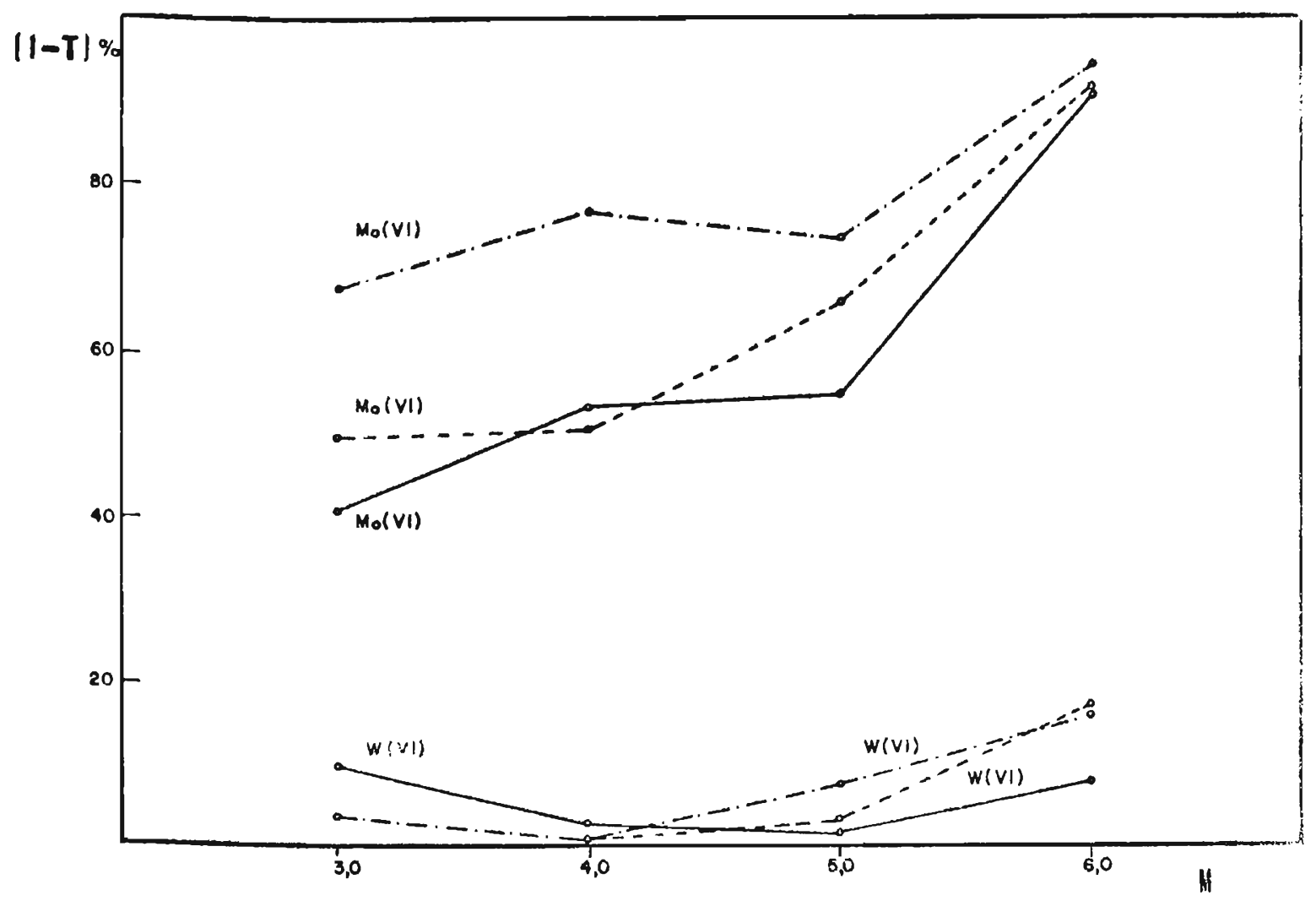

COHC. 花I

\section{FIGURA I}

Extratibilidade em solventes orgânicos do Mo(VI) e W(VI) em função da concentração de HCl.

$1 \mathrm{ml}$ fase aquosa: $1 \mathrm{ml}$ fase orgânica. reação com fenilfluorona

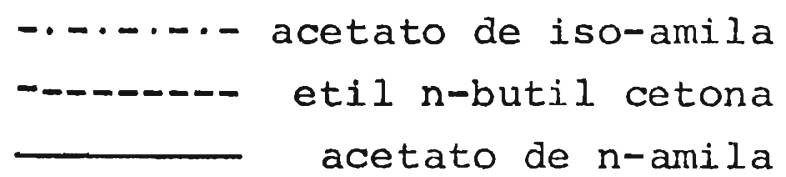




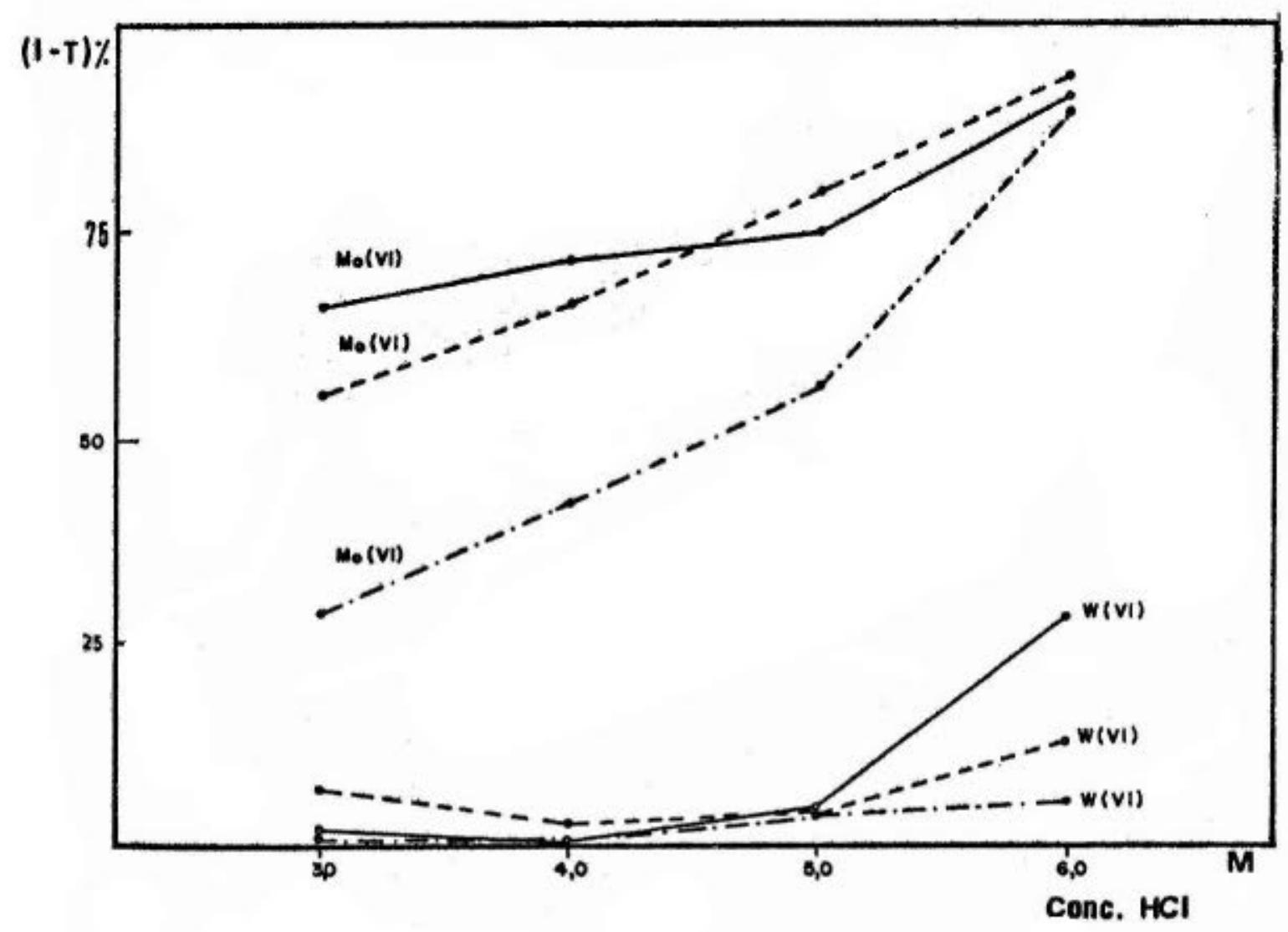

FIGURA 2

Extratibilidade em solventes orgânicos do Mo(VI) e W(VI) em função da concentração de $\mathrm{HCl}$.

1. ml fase aquosa: $1 \mathrm{ml}$ fase orgânica reação com fenilfluorona

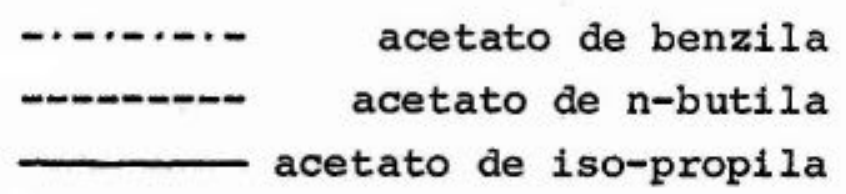


Pelo exame dos mesmos, observa-se que dificilmente se podería obter uma condição de acidez em que o Mo(VI) pudesse ser totalmente extraído e $\circ W(V I)$ se mantivesse em solução, uma vez que o aumento da acidez favoreceu igualmente a extração dos dois elementos.

Observe-se que, nesta altura do trabalho não for possivel compreender porque a extratibilidade nos dois sistemas - Mo(VI) e W(VI) não aumentou gradualmente como seria de se supor, com o aumento da acidez, mas sim verifí cou-se surpreendentes irregularidades.

Entretanto, o esclarecimento dêste fato. só foi possivel com o decorrer dos estudos em que se analisou a influência de vārios fatores sôbre o processo de extração e de desenvolvimento da cor. Por outro lado, tendo em vista que nesta primeira fase desejava-se obter apenas uma orientação de carāter geral, as conclusões a que se chegou podem ser consideradas satistiatórias.

Neste ponto dos estudos preliminares, abando nou-se os ensaios paralelos que se fez para os dois elemen tos, retornando-se à questão num capítulo especial em que se procurou explorar outros fatores, objetivando ou uma se paração ou uma determinação de um elemento na presença de outro.

Prosseguiu-se assim num estudo mais detalhado da extração do Mo(VI) escolhendo o acetato.de n-butila 
tendo em vista as vantagens que o solvente apresenta neste tipo de trabalho: baixa volatilidade, ponto de ebulição su perior a $100^{\circ} \mathrm{C}$, facilmente purificável, odor agradável e pequena solubilidade em soluções aquosas, inclusive ācidas. Observou-se também, que o desenvolvimento da cor do complexo molibdênio-fentlfluorona é instantâneo quando se usa acetato de n-butila, enquanto que para outros solventes isto nem sempre acontece.

Por outro lado, êste solvente tem sido usado em outros trabalhos de extração de Mo(VI), quer de complexos prèviamente formados em melo aquoso, quer na extração do elemento de soluções fortemente ãcidas.

3) ESTUDO QUALITATIVO DA EXTRAÇÃO DO Mo(VI)

Inicialmente procurou-se verificar qual a concentração de ácido mais indicada para a extração do Mo(VI) .

Na tabela 3 verifica-se o efeito da acidez sôbre a extração, quando se tem $1,0 \mathrm{ml}$ de meio aquoso contendo $5 \mu \mathrm{g}$ do elemento e se fez uma ünica extração com $1,0 \mathrm{ml}$ de solvente. 


\section{TABELA 3}

Extração de $5 \mu \mathrm{g}$ de Mo(VI) com acetato de n-butila em fun ção da concentração de ácido cloríarico.

$1 \mathrm{ml}$ fase aquosa: $1 \mathrm{ml}$ fase orgânica reação com fenilfluorona

\begin{tabular}{|c|c|c|}
\hline $\begin{array}{c}\mathrm{HCl} \\
\mathrm{N}\end{array}$ & $\mathrm{A}$ & $\begin{array}{c}\lambda \\
\mathrm{nm} \\
\vdots\end{array}$ \\
\hline 0,5 & 0,001 & 504 \\
1,0 & 0,002 & 504 \\
2,0 & 0,010 & 504 \\
4,0 & 0,154 & 504 \\
6,0 & 0,210 & 504 \\
8,0 & 0,174 & 504 \\
\hline
\end{tabular}

o melhor resultado ocorreu quando se partiu de soluções $6 \mathrm{~N}$ em HCl. Abaixo desta acidez a extratibilida de diminuiu e para $8,0 \mathrm{~N}$ em $\mathrm{HCl}$ em que seria de supor um re sultado mais alto em absorbância, surpreendentemente, ocor reu o contrário. Entretanto percebeu-se no decorrer das ex periências que o ácido clorídrico provoca o descoramento tanto do complexo de molibdênio em meio orgânico como do prōprio reagente. Por outro lado, a extração com solventes oxigenados de soluções fortemente ācidas arrasta consigo certo teor de ácido clorídrico explicando assim aquele efeito.

Para acidez superior a $8 \mathrm{~N}$ ocorreu miscibilidade completa das fases. 
Ressalte-se que è de todo conveniente extrair o Mo(VI) do sistema clorídrico na menor acidez possí vel uma vez que, de modo geral, um aumento de acidez favorece a extração de outros Ions, principalmente W(VI), $\mathrm{Nb}(\mathrm{V}), \mathrm{Fe}(\mathrm{III})$ e $\mathrm{V}(\mathrm{V})$.

4) ESTUDO QUANTITATIVO DA EXTRAÇ̃̃O DE MOLIBDENIO

Procedeu-se ao estudo da extração do Mo(VI) de soluções $6 \mathrm{~N}$ em $\mathrm{HCl}$, (adicionando-se $0,5 \mathrm{ml}$ de $\mathrm{HCl}$ concentrado a $0,5 \mathrm{ml}$ de solução) executando-se tres extrações consecutivas com $1 \mathrm{ml}$ do solvente a partir de $1 \mathrm{ml}$ de meio aquoso, resultando no final do processo aproximadamente 3 $\mathrm{ml}$ de extrato orgânico. Adicionou-se $2 \mathrm{ml}$ do reagente e completou-se o volume de $10 \mathrm{ml}$ com alcool etilico.

Os resultados obtidos destas extrações não apresentaram a reprodutividade necessária que indicasse ex tração perfeitamente idêntica em todas as amostras, chegan do inclusive a discrepâncias de 108 entre elas em termos de concentração. Entretanto, procurou-se manter esta condi ção de acidez julgando haver outro fator afetando o proces so de extração. Passou-se assim a fazer um controle rigoro so das condições em que os ensaios eram executados. 
Mantendo-se constante para todas as amostras - tempo de agitação e a ordem de adição dos reagentes, observou-se que ao se adicionar $\circ \mathrm{HCl}$ concentrado à solução aquosa foi necessário homogenizar, mediante ligeira agitação da solução e esperar alguns segundos antes de se adicionar o solvente para a extração.

Na tabela 4 observa-se o efeito do contacto do ácido clorídrico com a solução contendo Mo(VI) em função do tempo, antes de se proceder à extração.

\section{TABELA 4}

Influência do tempo no contācto do ācido cloríarico com a solução.

Extração de $10 \mu \mathrm{g}$ de Mo(VI) - Reação com fenilfluorona

\begin{tabular}{|c|c|}
\hline TEMPO & $\begin{array}{c}\stackrel{\nexists}{?} \\
(504 \mathrm{~nm}) \\
\end{array}$ \\
\hline $\begin{array}{l}t \rightarrow 0 \text { (adição do solvente imediatamente após } \\
\text { adição do ácido) }\end{array}$ & 0,387 \\
\hline $\begin{array}{c}\text { segundos (adição do solvente após homogeni } \\
\text { zar o meio com o ācido) }\end{array}$ & 0,422 \\
\hline $5 \mathrm{~min}$ & 0,431 \\
\hline $10 \mathrm{~min}$ & 0,427 \\
\hline $15 \mathrm{~min}$ & 0,434 \\
\hline $20 \mathrm{~min}$ & 0,422 \\
\hline $30 \mathrm{~min}$ & $0,4.36$ \\
\hline
\end{tabular}


5) COEFICIENTE DE EXTRAÇÃO*

Determinou-se o coeficiente de extração utilizando-se una solução de molibdato de amônio irradiado. A contagem de molibdênio nas duas fases permitiu calcular a porcentagem de extração para uma faixa de concentração do elemento. A partir de $1 \mathrm{ml}$ de fase aquosa e $1 \mathrm{ml}$ de fase orgânica, procedeu-se à extração e lavou-se com duas porções de $0,5 \mathrm{ml}$ de solventes. Os resultados acham-se reunidos na tabela 5 .

TABELA 5

Coeficiente de Extração

$2 \mathrm{ml}$ fase aquosa: $2 \mathrm{ml}$ fase orgânica

\begin{tabular}{|c|c|}
\hline $\begin{array}{c}\text { Mo na } \\
\text { fase aquosa } \\
\mu g\end{array}$ & $\begin{array}{c}\text { \&े de } \\
\text { Extração }\end{array}$ \\
\hline & \\
10 & 81,2 \\
20 & 81,8 \\
30 & 82,5 \\
40 & 81,6 \\
81,2 \\
\hline
\end{tabular}

*Agredeço a gentileza de Elisa K. Tomida e do Dr. Alcídio Abrão, do Instituto de Energia Atômica, que tornarain possí vel as determinações com o molibdênio marcado. 
6) CONSIDERAÇð̄ES SOBBRE A ESPECIE EXTRAIDA

I. Nelidow e Diamond ${ }^{(60)}$ estudando o mecanis mo de extração do Mo(VI) de soluções clorídricas concluiram que a espécie extraível è de förmula $\mathrm{MoO}_{2} \mathrm{Cl}_{2}$, possivelmente solvatada com āgua e solvente. Busev e colaboradores (61) por outro lado, ao examinarem o extrato orgânico no infravermelho e no ultra-violeta, obtido por extração do elemen to de soluções cloríaricas com solventes oxigenados, reafin maram as observações de Nelidow ${ }^{(60)}$ concluindo definitivamente tratar-se da espécie $\mathrm{MOO}_{2} \mathrm{Cl}_{2}$ solvatada por uma molécula do solvente e uma molécula de ãgua.

Outros autores $(15,62)$, que estudaram não só - Mo(VI) como também o $C r(I I I), W(V I), V(V)$ extraindo-os de soluções clorídricas com fosfato de tri-n-butila e fosfato de di-n-butila, estabeleceram a composição das espécies extraíveis como sendo $\mathrm{MOO}_{2} \mathrm{Cl}_{2}: 2 \mathrm{Bu}_{3} \mathrm{PO}_{4}$ ou $\mathrm{MOO}_{2}$ : $2 \mathrm{Bu}_{2} \mathrm{HPO}_{4}$, ao passo que para $\circ \mathrm{Cr}(\mathrm{III})$ e $\circ \mathrm{V}(\mathrm{V})$ as fórmulas $\mathrm{HCrO}_{3} \mathrm{Cl}: 2 \mathrm{Bu}_{3} \mathrm{PO}_{4}$ e $\mathrm{HVO}_{2} \mathrm{Cl}_{2} \cdot 2 \mathrm{Bu}_{3} \mathrm{PO}_{4}$.

Já Nelidow e Diamond ${ }^{(60)}$ haviam notado que, comparado com outros elementos, o molibdênio mostrava menor dependência da acidez com relação à sua extratibilidade. Ao contrário dos outros elementos o molibdênio era extraído numa forma neutra sem a participação de prótons. Neste trabalho os autores indicaram ainda que em soluções fortemente ácidas - acima de $7 \mathrm{~N}$ em $\mathrm{HCl}$ - formam-se espé- 
cies do tipo $\mathrm{MOO}_{2} \mathrm{Cl}_{3}^{-}$, MoO(OH) $2_{3}^{-3}$ e $\mathrm{MOO}_{2} \mathrm{Cl}_{4}^{-2}$ de baixa extratibilidade.

Os resultados aqui obtidos evidenciam que a falta de homogeneidade da solução e o tempo de espera após a adição do ácido clorídrico, antes de executar a extração fizeram com que nem sempre se obtivesse o molibdênio total mente na sua forma extraível $-\mathrm{MoO}_{2} \mathrm{Cl}_{2} \cdot$ Tais observações poderão levar à explicação, tambēm, daquelas discrepâncias menclonadas no estudo comparativo da extração do Mo(VI) e W(VI), cujos resultados foram apresentados nos grăficos das figuras 1 e 2 .

7) PROCEDIMENTO PARA A EXTRAÇÃO

Estabeleceu-se como norma para o estudo posterior extrair o molibdênio(VI) de solução aquosa da seguinte maneira:

Num tubo de extração contendo $0,5 \mathrm{ml}$ de solu Ção de molibdato de sódio, adiciona-se $0,5 \mathrm{ml}$ de ácido clo rídrico concentrado, agita-se ligeiramente a solução e adi ciona-se após alguns segundos, 1,0 ml de acetato de n-but1 la. Agita-se aproximadamente 20 segundos, centrifuga-se e separa-se a fase orgânica com uma pipeta de extração. Extrai-se novamente, com mais duas passagens, adicionando-se em cada uma $1,0 \mathrm{ml}$ do solvente. Os extratos são tocios reunidos em balão de $10,0 \mathrm{ml}$. 


\section{III - ELABORAÇÃO DO METODO ANALITICO}

1) CONSIDERAÇÕES GERAIS - PREPARO DA SOLUÇÃO DO REAGENTE.

Os trabalhos de cluley (41), schneider e Sandell $(50)$ Luke e Camphell ${ }^{(52)}$ e outros $(48,46)$ que utilizaram a fenilfluorona como reagente colorimētrico em meio aquoso mostraram diferentès maneiras de se preparar e utilizar o complexante.

Por outro lado, no trabalho de Lilia Sant' Agostino(57), em que utilizou a fenilfluorona em meio orgâ nico como reagente para o germânio, fez-se amplo estudo vị sando verificar o efeito do solvente e do äcido na prepara ção da solução. Os melhores resultados obtiveram-se quando se partiu da concentração indicada por cluley ${ }^{(41)}$ e se dis solveu o complexante numa solução de proporção definida en tre álcool e ácido sulfúrico.

Em vista disso utilizou-se neste trabalho o reagente preparado da mesma maneira. 
2) ESTUDO DA REAÇÃO MOLIBDENIO(VI) - FENILFLUORONA EM MEIO ORGÃNICO.

Tendo-se verificado que o Mo(VI), extraído em acetato de n-butila de soluções ácidas reage instantaneamente com uma solução alcoōlica sulfúrica no próprio solvente, passou-se a estudar as características espectrais dessas soluções.

Procedimento: Aos extratos orgânicos de duas amostras inde pendentes adicionou-se $2,0 \mathrm{ml}$ do reagente e completou-se o volume de $10,0 \mathrm{ml}$ com álcool etílico. Obteve-se um branco nas mesmas condições e determinou-se o espectro de absorção do complexo que se forma entre o molibdênio e a fenilfluorona contra o branco. o espectro diferencial que se ob teve apresentou um máximo de absorção para o comprimento de onda correspondente a 504 nm (figura 3).

Para melhor elucidar as características das soluções em estudo, achou-se conveniente determinar os es pectros contra o solvente, tanto da solução contendo o com plexo molibdênio-fenilfluorona, quanto do pröprio reagente. E evidente que a diferença entre êsses dois dará um es pectro semelhante ao da figura 3 .

Na figura 4 observam-se os referidos espectros para duas concentrações do Mo(VI) na diluição final e os respectivos diferenciais dessas mesmas soluções obtidos experimentalmente. 


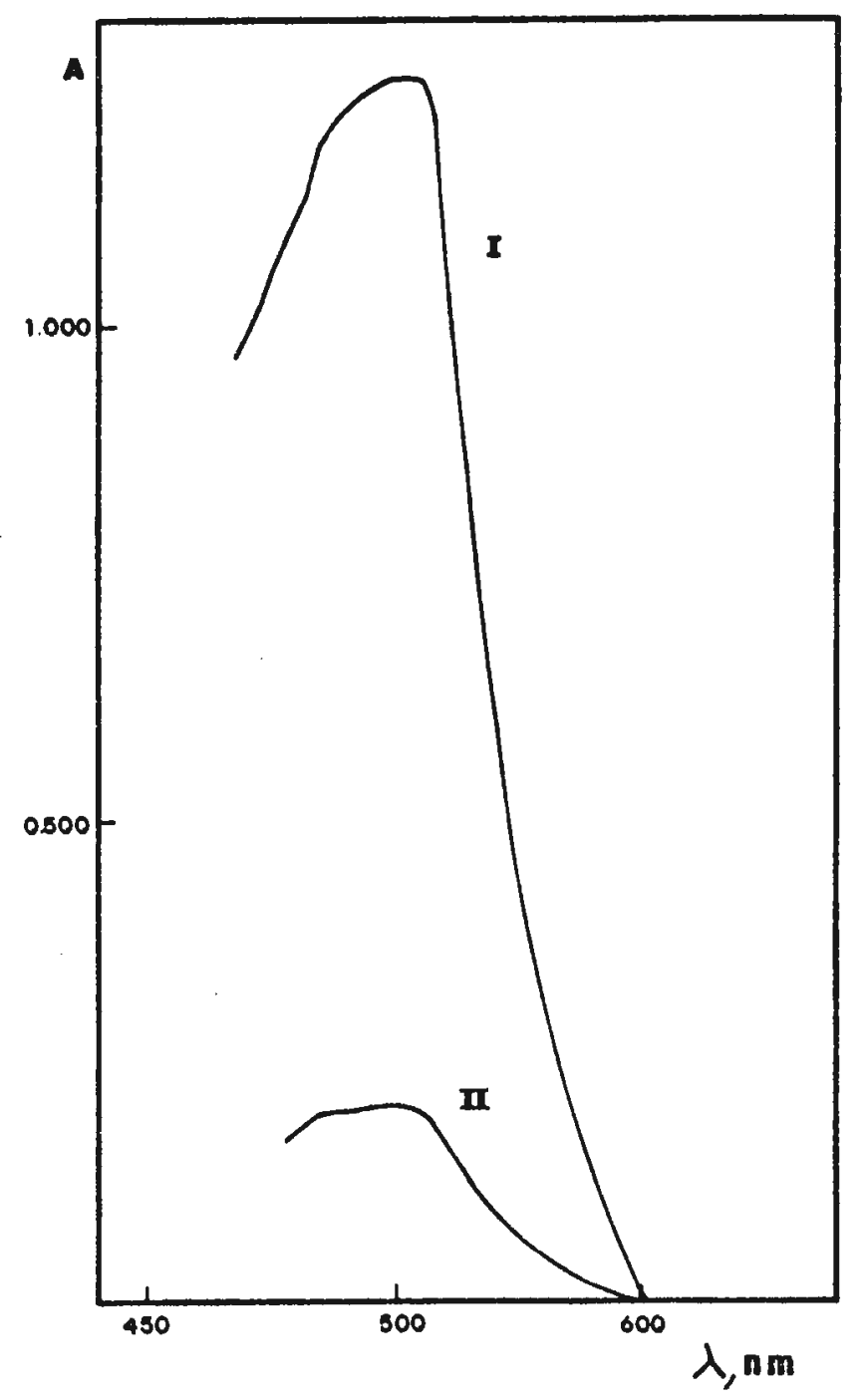

FIGURA 3

Espectros de absorção da solução molibdênio(VI) -fenilfluorona contra o reagente.

I $-3,0 \mu g / m l$ na diluição final II - $0,5 \mu \mathrm{g} / \mathrm{ml}$ na diluição final 


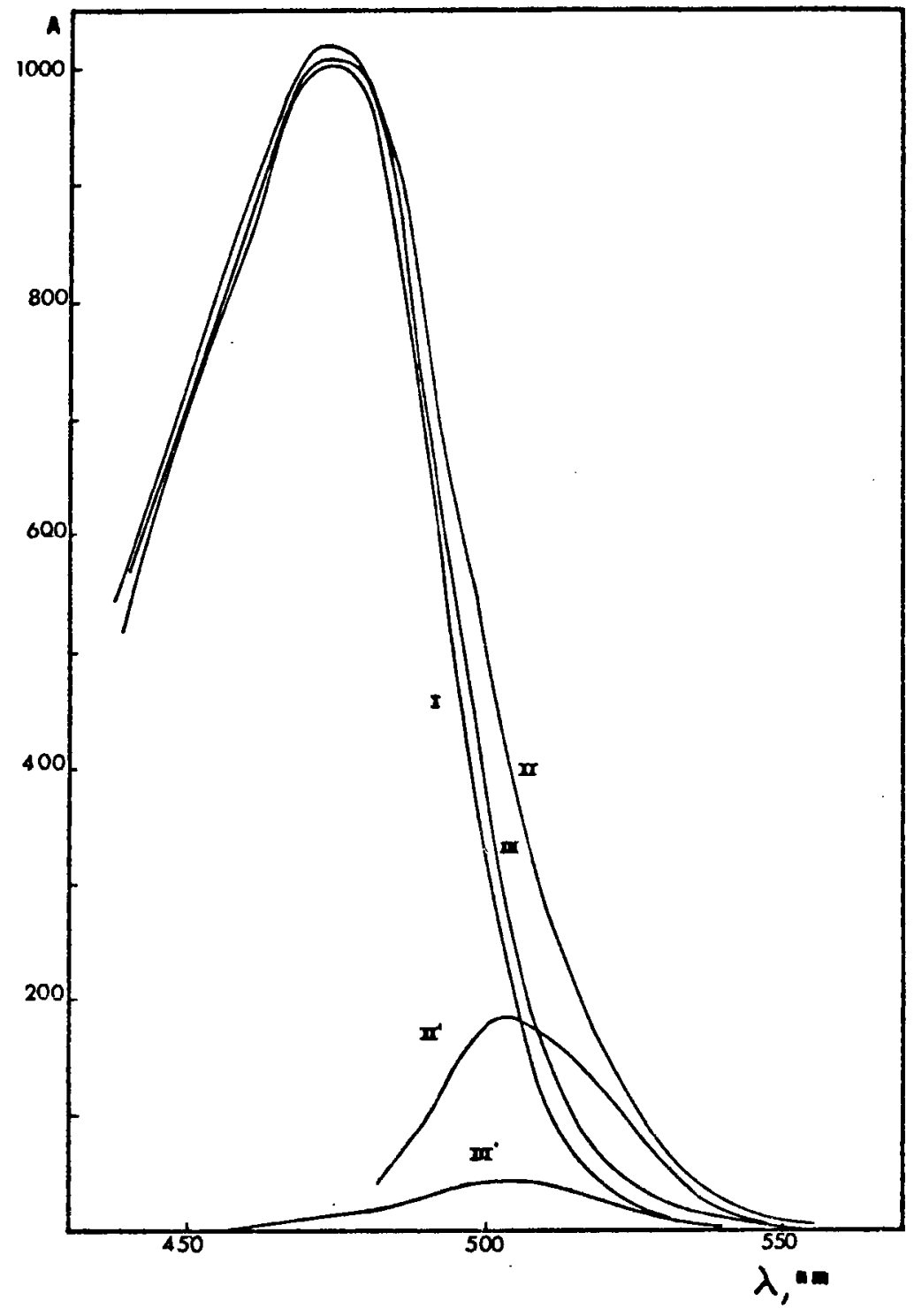

FIGURA 4

I - Espectro de absorção do reagente contra o solvente II e III - Espectros de absorção das soluções obtidas da reação entre Mo(VI) e a fenilfluorona contra o solvente para 0,5 e 2,0 $\mu \mathrm{g}$ do Mo(VI) na diluição final.

II'e III'- Espectros de absorção das soluções anteriores contra o reagente. 
Procedimento: Aos extratos orgânicos de tres amostras inde pendentes, sendo a primeira isenta de molibdênio e as outras contendo 0,5 e $2,0 \mu g$ do elemento, adicionou-se $2 \mathrm{ml}$ do reagente e completou-se o volume de $10 \mathrm{ml}$ com alcool etílico. Estas soluções foram medidas contra o solvente, ob tendo-se os espectros I, II e III da figura 4. As duas soluções contendo o molibdênio(VI) foram medidas contra a so lução isenta do elemento (branco), obtida nas mesmas condi ções. Teve-se os espectros II' e III' na mesma figura. Nes tas determinações utilizou-se cubas de corex de 0,2 cm de caminho ötico.

3) INFLUENCIA DO VOLUME DO REAGENTE

Com o objetivo de verificar o volume de reagente que se deve adicionar ao extrato orgânico afim de ga rantir tanto a reação completa como tambēm um excesso de reagente que não afete o resultado das determinações, estú dou-se o efeito da adição de diferentes volumes do reagente ao extrato orgânico.

A figura 5 mostra que, a partir de 1,0 $\mathrm{ml}$ de solução, jā se obteve o resultado satisfatōrio lquando se extraiu loug do Mo(VI) \}. Entretanto, preferiu-se utilizar em todos os ensaios $2,0 \mathrm{ml}$ do reagente tendo em vista os casos em que se procurou extrair maiores teores do elemento. 
Observe-se que a fenilfluorona, quando se adiciona $2,0 \mathrm{ml}$ às amostras, está presente num excesso de 4 a 20 vêzes a razão molar, admitindo-se a proporção de 1:l entre o elemento e o complexante. (ver estudo posterior felto a respeito - cap. 'V). 


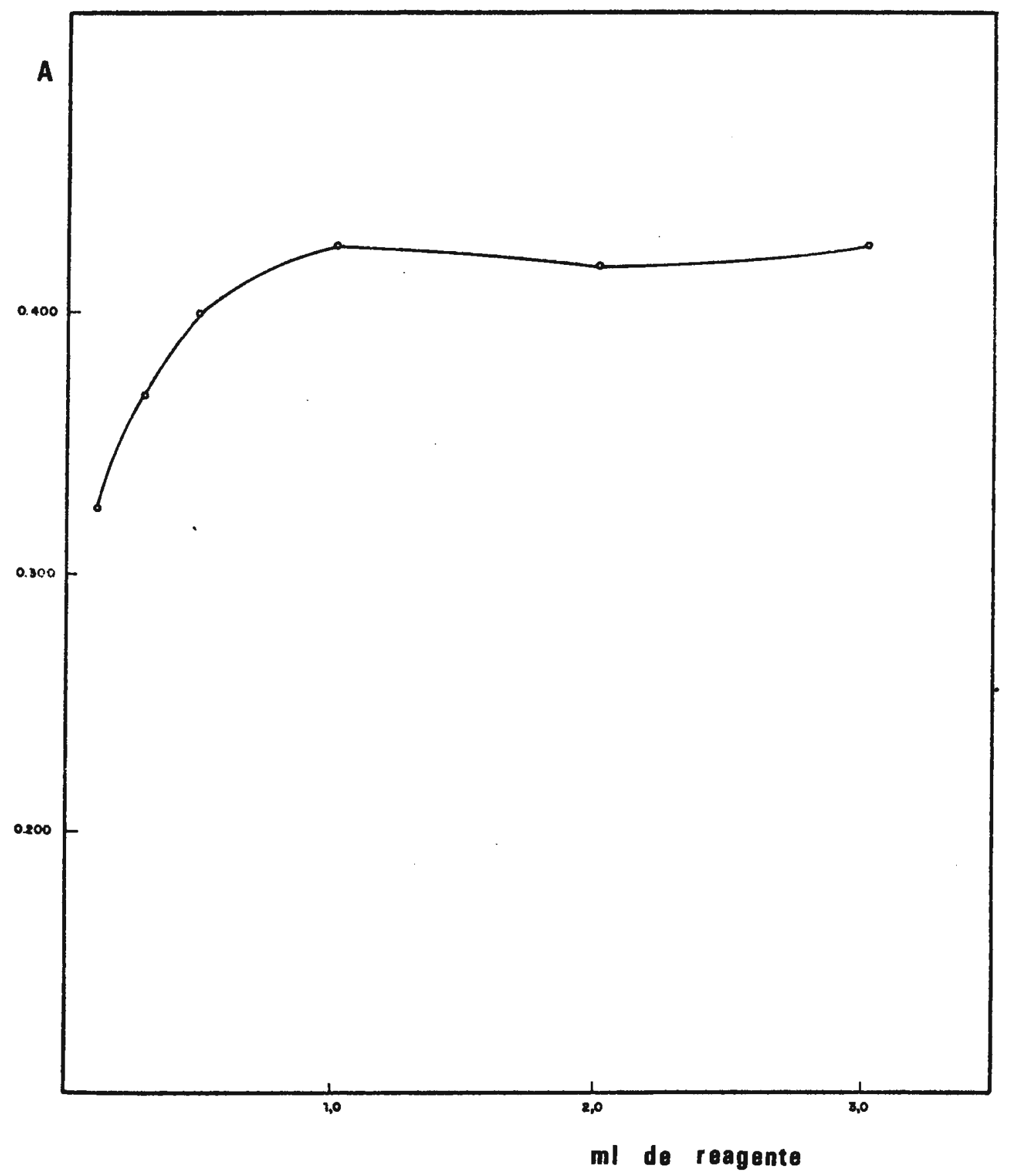

FIGURA 5

Efeito do volume do reagente

Extração de $10 \mu \mathrm{g}$ Mo(VI) - diluição final 1,0 $\mathrm{\mu g} / \mathrm{ml}$

Reação com fenilfluorona $-\lambda=504 \mathrm{~nm}$ 
Procedimento: Aos extratos orgânicos de uma série de extrạ ções de $10 \mu g$ de molibdênio adicionou-se volumes variáveis do reagente e completou-se 0 volume de $10,0 \mathrm{ml}$ com álcool etílico. Cada amostra foi medida contra um branco obtido da mesma maneira. Os resultados acham-se reunidos na tabela 6 .

\section{TABELA 6}

Influência do volume do reagente

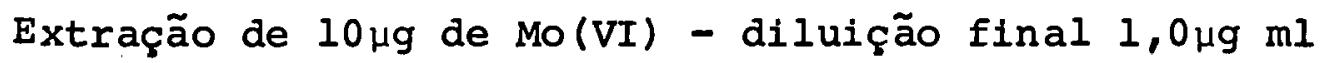

\begin{tabular}{|c|c|}
\hline Reagente (m) & $A(504 \mathrm{~nm})$ \\
\hline 0,10 & 0,321 \\
0,25 & 0,366 \\
0,50 & 0,401 \\
1,00 & 0,417 \\
2,00 & 0,414 \\
3,00 & 0,420 \\
\hline
\end{tabular}

4) INFLUENCIA DO NOMERO DE EXTRAÇÕES.

Em todos os ensaios anteriores usou-se sempre tres $m l$ de acetato de n-butila em tres extrações suces sivas de $1+1+1 \mathrm{ml}$. Entretanto, considerou-se de interêsse detalhar êste estudo com o fim de verificar quantas extra- 
ções são realmente necessārias e qual o efeito do volume do solvente nas determinações.

Fez-se duas sēries de extrações para duas concentrações diferentes, variando o nưmero de extrações e mantendo o volume da fase orgânica de $1 \mathrm{ml}$.

\section{TABELA 7}

Influência do número de extrações

\begin{tabular}{|c|c|c|c|}
\hline \multirow{2}{*}{$\begin{array}{c}\text { n\& de } \\
\text { extrações }\end{array}$} & \multirow{2}{*}{$\begin{array}{c}\text { volume de } \\
\text { solvente }\end{array}$} & \multicolumn{2}{|c|}{$\mathrm{A}(504 \mathrm{~nm})$} \\
\cline { 3 - 4 } & 1 & 0,159 & 0,370 \\
2 & $1+1$ & 0,219 & 0,440 \\
3 & $1+1+1$ & 0,214 & 0,431 \\
4 & $1+1+1+1$ & 0,207 & 0,412 \\
\hline
\end{tabular}

A tabela 7 indica que uma única extração é insuficiente, sendo necessārio extrair 2 a 3 vêzes. Surpreendentemente, observa-se uma queda gradual nos valores de absorbância, principalmente quando se extrai quatro vezes. O mesmo se observou quando se refez diversas vezes a experiância. Este fato fez supor que a relação entre os vo Iumes de solvente e álcool etílico (éste usado para se com pletar o volume) deve ter alguma influência na cor do complexo. Portanto, passou-se a estudar a influēncia do solvente que se emprega para completar o volume da solução. 
5) EFEITO DA VARIAÇÃO DO SOLVENTE ADICIONADO AO EXTRATO OR GANICO APÓS A REAÇÃO COLORIMETRICA.

Utilizou-se, para êste estudo, além do acetạ to de n-butila e o álcool etílico, um conjunto de solventes que se considerou de maior praticidade para êste tipo de trabalho.

As amostras obtidas da extração de $10 \mu \mathrm{g}$ de Mo(VI) com 2,0 ml de acetato, apōs adição do reagente, completou-se o volume de $10 \mathrm{ml}$ com diversos solventes. Os valores apresentados na tabela 8 foram medidos no comprimento de onda correspondente ao máximo de absorção. 


\section{TABELA 8}

Efeito da variação do solvente sôbre a reação colorimētrica. Extração de $10 \mu \mathrm{g}$ Mo(VI)

\begin{tabular}{|l|c|c|}
\hline \multirow{2}{*}{ Solvente } & \multicolumn{2}{|c|}{$10 \mu \mathrm{g}$ Mo (VI) } \\
\cline { 2 - 3 } acetato n-butila & $\mathrm{A}$ & $\lambda$ max \\
álcool etílico & 0,406 & 504 \\
Metil isobutil cetona & 0,443 & 506 \\
Benzeno & 0,437 & 504 \\
Acetona & 0,250 & 514 \\
Eter etílico & 0,344 & 502 \\
Dioxano & 0,331 & 504 \\
Etilenoglicol & 0,397 & 500 \\
cloroförmio & descoramento \\
tetracloreto de & intenso \\
carbono & emulsão \\
\hline
\end{tabular}

Resultou que os melhores valores foram obtidos quando se utilizou álcool etílico ou metil-isobutil-ce tona, confirmando a suposição anterior de que o acetato de n-butila por sí descolore tenuamente o complexo. Ainda se depreendeu desses resultados um ligeiro deslocamento do má ximo de absorção de $504 \mathrm{~nm}$ para $506 \mathrm{~nm}$, quando se usou $2,0 \mathrm{ml}$ de acetato e se completou com álcool etílico.

Este fato, aparentemente irrelevante, ofereceu entretanto a possibilidade de se trabalhar num comprimento de onda mais favorāvel uma vez que a amostra de refe rência (contendo apenas o reagente) passou a absorver bem 
menos neste comprimento de onda; isto pode ser observado pelos dados a seguir em que a mesma foi determinada contra o solvente.

\begin{tabular}{|c|c|}
\hline$\lambda(\mathrm{nm})$ & $\mathrm{A}$ \\
\hline 502 & 1,155 \\
504 & 0,963 \\
506 & 0,762 \\
\hline
\end{tabular}

Estabeleceu-se como norma utilizar $2,0 \mathrm{ml}$ de acetato de n-butila ao Invēs de $3,0 \mathrm{ml}$, aumentando assim a relação entre álcool e solvente.

A tabela 9 indica que se obtem melhor resultado quando se faz 3 extrações com $(1+0,5+0,5)$ ml de solvente no lugar de 2 extrações com $(1+1) \mathrm{ml}$; na tabela 10 observa-se a reprodutividade das medidas espectrofotométri cas para duas concentrações. 


\section{TABELA 9}

Efeito do nümero de extrações para $2 \mathrm{ml}$ do solvente

\begin{tabular}{|c|c|c|}
\hline N8 extrações & \multicolumn{2}{|c|}{$A(506 \mathrm{~nm})$} \\
\cline { 2 - 3 } $2 \mathrm{ml}$ solvente & $10 \mu \mathrm{g}$ & $20 \mu \mathrm{g}$ \\
\hline $1+1$ & 0,439 & 0,870 \\
$1+0,5+0,5$ & 0,447 & 0,884 \\
\hline
\end{tabular}

TABELA 10

Reprodutividade das determinações

\begin{tabular}{|c|c|}
\hline \multicolumn{2}{|c|}{$A(506 \mathrm{~nm})$} \\
\hline $10 \mu \mathrm{g}$ & $20 \mu \mathrm{g}$ \\
\hline 0,449 & 0,896 \\
0,438 & 0,889 \\
0,442 & 0,896 \\
0,437 & 0,876 \\
0,447 & 0,882 \\
\hline
\end{tabular}

6) EFICIENCIA DA EXTRAÇÃO - REVERSÃO A FASE AQUOSA

Apesar de ser ter verificado, pela determina ção do coeficiente de extração (pg 34), a possibilidade de separar o Mo(VI) do meio aquoso, considerou-se de interesse fazer um estudo da reversão à fase aquosa, seguida de 
reextração e determinação espectrofotomētrica uma vez já estabelecidas as condições de reprodutividade.

Verificou-se que tanto a reversão à fase aquosa quanto a reextração são perfeitamente quantitativas (tabela 11). Os valores ligeiramente inferiores que se obtem com a reversão devem ser atribuidos às pequenas perdas ocorridas durante as tres etapas de extração que se efetuam com vărias operações.

\section{TABELA 11}

Estudo da reversão à fase aquosa seguida de nova extração e determinação espectrofotométrica

\begin{tabular}{|l|c|c|c|}
\hline & \multicolumn{3}{|c|}{$\mathrm{A}(506 \mathrm{~nm})$} \\
\cline { 2 - 4 } sem reversão & $5 \mu \mathrm{g}$ & $10 \mu \mathrm{g}$ & $20 \mu \mathrm{g}$ \\
\cline { 2 - 4 } com reversão & 0,225 & 0,447 & 0,882 \\
& 0,221 & 0,422 & 0,833 \\
\hline
\end{tabular}

Procedimento: Os extratos orgânicos de tres amostras de di ferentes concentrações foram recebidos em $0,5 \mathrm{ml}$ de solução $0,2 \mathrm{M}$ em KOH. Agitou-se, centrifugou-se, e após separar - solvente, o mesmo foi rejeitado. Seguiu-se esse andamento para as três etapas da extração, recebendo-se os extratos sôbre a mesma solução de KOH. As soluções aquosas restantes, adicionou-se $0,5 \mathrm{ml}$ de $\mathrm{HCl}$ concentrado e se procedeu à extração e determinação espectrofotométrica como já indicado. 
7) ESTABILIDADE DA COR

As soluções mostraram-se muito estáveis com relação ao poder de absorção. Obtiveram-se medidas perfeitamente reprodutíveis apōs 24 horas, mesmo quando expostas à luz comum. (tabela 12).

Constatou-se, de maneira geral que, amostras guardadas ao abrigo da luz retinham seu poder de absorção por vārias semanas. A ligeira queda na absorção que se observou depois de muito tempo atribuiu-se à formação de perōxidos no solvente que, lentamente, reagem com fenilfluorona.

\section{TABELA 12}

Influência do tempo nas medidas espectrofotomētricas

\begin{tabular}{|c|c|c|c|}
\hline \multirow{2}{*}{ Tempo } & \multicolumn{3}{|c|}{$\mathrm{A}(506 \mathrm{~nm})$} \\
\cline { 2 - 4 } & $5 \mu \mathrm{g}$ & $10 \mu \mathrm{g}$ & $20 \mu \mathrm{g}$ \\
\hline $5^{\prime}$ & 0,225 & 0,447 & 0,882 \\
$10^{\prime}$ & 0,224 & 0,445 & 0,884 \\
$30^{\prime}$ & 0,224 & 0,445 & 0,883 \\
1 hora & 0,226 & 0,441 & 0,883 \\
6 horas & 0,225 & 0,441 & 0,880 \\
12 horas & 0,223 & 0,442 & 0,878 \\
24 horas & 0,223 & 0,443 & 0,880 \\
\hline
\end{tabular}


8) PROPORCIONALIDADE DOS VALORES - IEI DE BEER.

o sistema mostrou obedecer a lei de LambertBeer para o intervalo de concentração de 0,10 a $2,5 \mu \mathrm{g}$ de Mo/mI na diluição final - figura 6 .

9) REGIÃO DE CONCENTRAÇÃO FAVORÃVEL GRÁFICO DE RINGBOM.

Com os valores da tabela 13 construiurse o grāfico segundo Ringbom ${ }^{(63)}$ para verificar a região mais favorāvel de determinação; estã compreendida entre 0,45 e

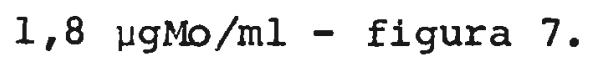


53

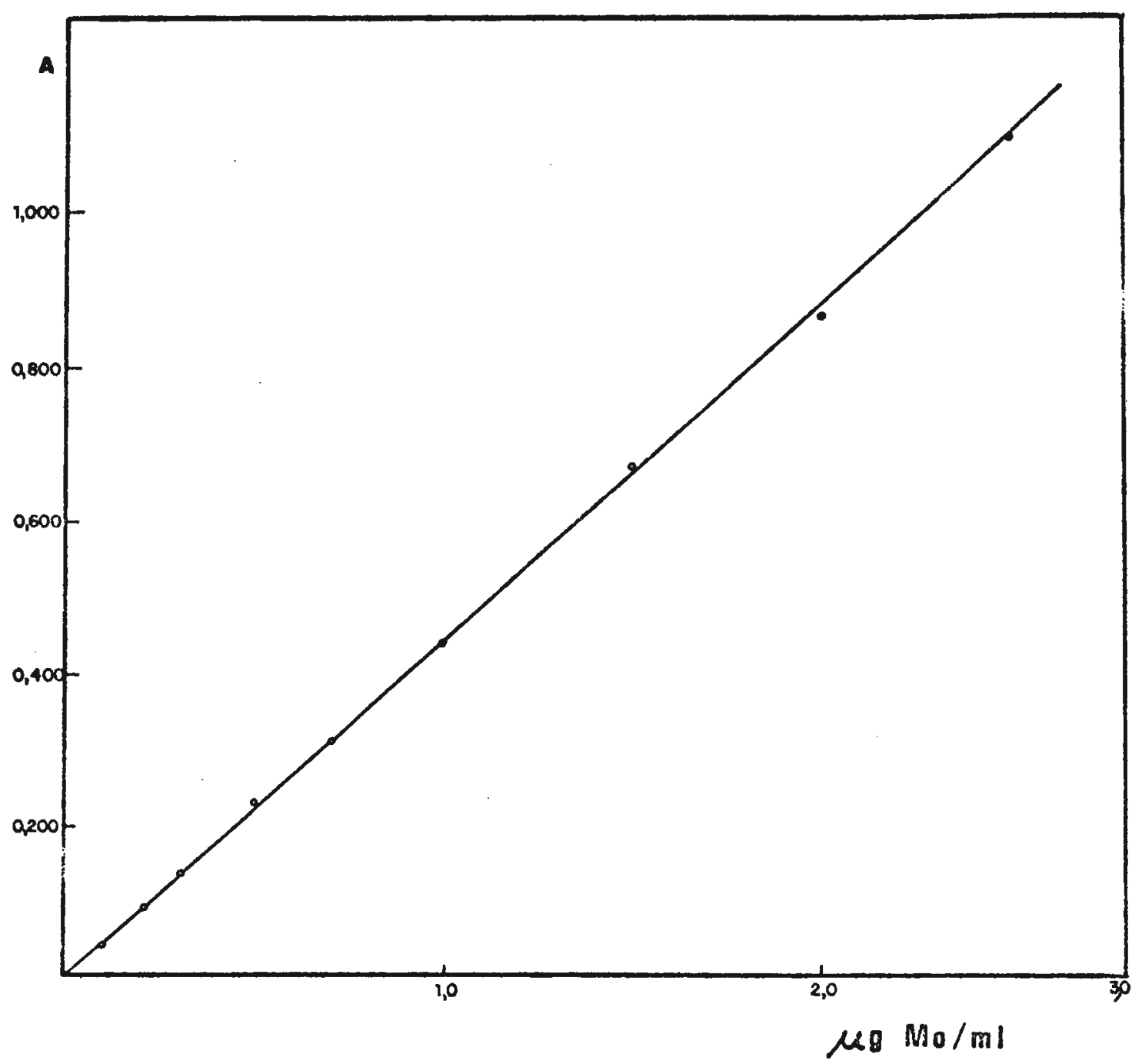

FIGURA 6

Proporcionalidade dos valores Verificação da Lei de Lambert-Beer $\lambda=506 \mathrm{~nm}$ 


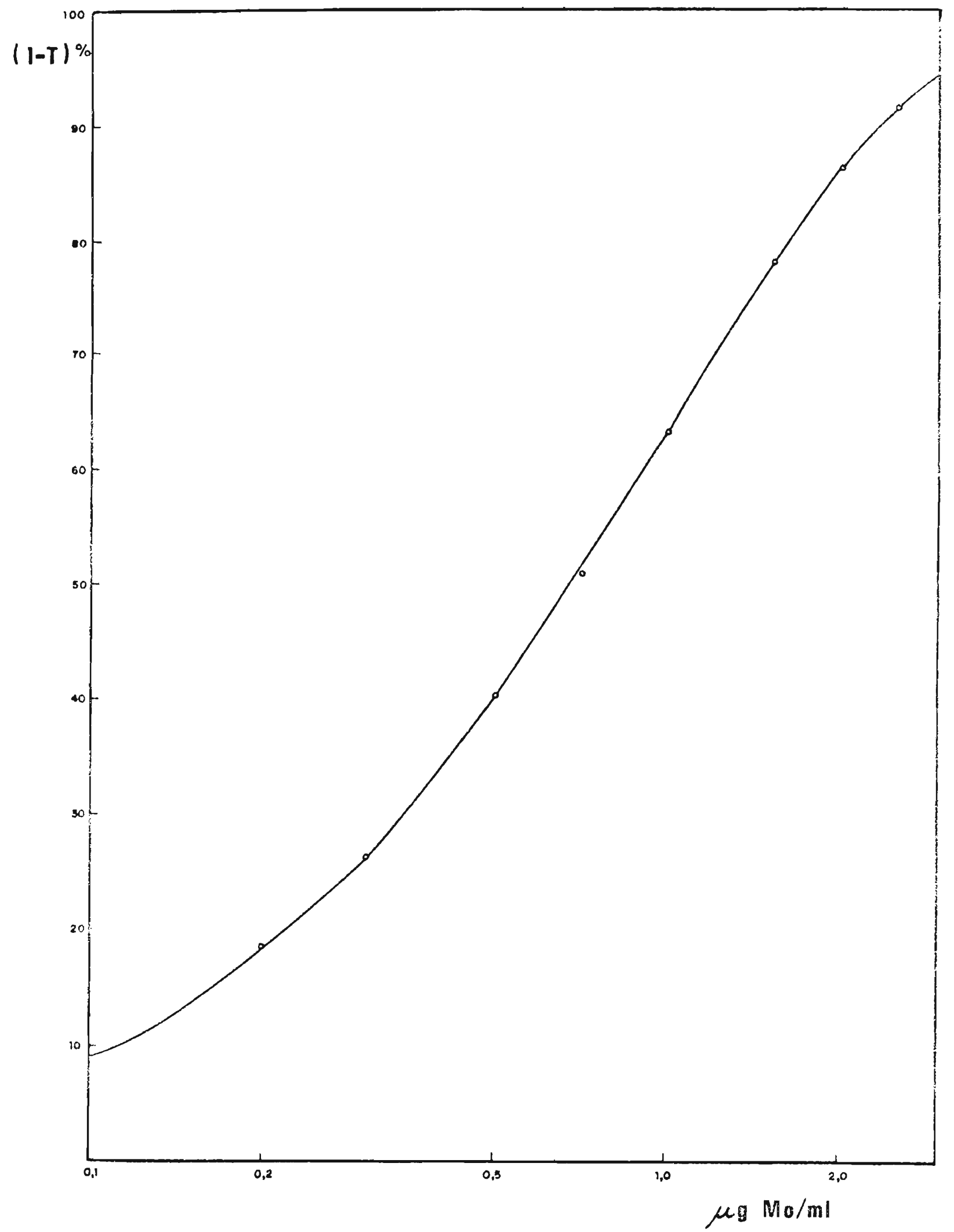

FIGURA 7

Região favorăvel de determinação Gräfico de Ringbom$$
\lambda=506 \mathrm{~nm}
$$ 


\section{TABELA 13}

Proporcionalidade dos valores

\begin{tabular}{|c|c|c|}
\hline $\begin{array}{c}\text { Mo } \\
\mu \mathrm{g} / \mathrm{ml}\end{array}$ & $(1-\mathrm{T}) \mathrm{q}$ & $\begin{array}{c}\mathrm{A} \\
506 \mathrm{~nm}\end{array}$ \\
\hline 0,10 & 9,2 & 0,042 \\
0,20 & 18,7 & 0,090 \\
0,30 & 26,2 & 0,132 \\
0,50 & 40,6 & 0,226 \\
0,70 & 51,0 & 0,310 \\
1,0 & 63,6 & 0,439 \\
1,5 & 78,4 & 0,665 \\
2,0 & 86,7 & 0,863 \\
2,5 & 92,0 & 1,097 \\
\hline
\end{tabular}

10) PRECISÃO DO MẼTODO

Foram feitas duas séries de determinações in dependentes para se avaliar a precisão do mëtodo. Os resul tados estão reunidos na tabela 14 . 


\section{TABELA 14}

Precisão do mētodo

Extração de $5 \mu \mathrm{g}$ de Mo

$A(506 \mathrm{~nm})$

\begin{tabular}{|llll|}
\hline \multicolumn{4}{c|}{$A(506 \mathrm{~nm})$} \\
0,222 & 0,221 & 0,211 & 0,222 \\
0,219 & 0,218 & 0,208 & 0,215 \\
0,212 & 0,215 & 0,215 & 0,210 \\
0,209 & 0,215 & 0,213 & 0,212 \\
0,218 & 0,214 & 0,221 & 0,214 \\
\hline
\end{tabular}

Média: 0,215

Desvio Mēdio: 0,0034

Estimativa do desvio Padrão(s): 0,0045

L. $C(0,95)=0,0021$

\begin{tabular}{|cccc|}
\hline \multicolumn{4}{|c|}{$\begin{array}{c}\text { Extração de } 10 \mu \mathrm{ug} \text { de Mo } \\
\text { A(506nm) }\end{array}$} \\
\hline 0,429 & 0,443 & 0,427 & 0,444 \\
0,444 & 0,437 & 0,430 & 0,442 \\
0,426 & 0,434 & 0,432 & 0,439 \\
0,429 & 0,438 & 0,449 & 0,437 \\
0,446 & 0,443 & 0,446 & 0,434 \\
\hline
\end{tabular}

Mēdia: 0,437

Desvio Médio: 0,0059

Estivativa do desvio Padrão(s): 0,0069

L. $C(0,95)=0,0033$

Fazendo-se a conversão da média e dos corres pondentes limites de confiança $(95 q){ }^{(66)}$ em termos de microgramas de molibdênio encontrados na amostra, obteve-se o valor de $5,00 \pm 0,05 \mu \mathrm{g}$ e $10,00 \pm 0,08 \mu \mathrm{g}$ de Mo. 
11) ABSORTIVIDADE MOLAR

A absortividade molar do complexo calculado a partir do gräfico da figura 6 representativo da lei de Lam bert-Beer correspondeu ao valor de 42.122 .

12) PROCEDIMENTO ANALITICO

Soluções e reagentes

- Solução de fenilfluorona: dissolver $0,050 \mathrm{~g}$ de fenilfluorona, em banho maria a $70^{\circ} \mathrm{C}$, em $200 \mathrm{ml}$ de álco ol etílico contendo 12,5 ml de ácido sulfúrico 1:6. Deixar esfriar e levar o volume a $250 \mathrm{ml}$ com álcool etílico.

- Ácido clorídrico concentrado p.a.

- Acetado de n-butila isento de peróxidos.

- Alcool etílico isento de aldeído.

Pipetar em um tubo de extração uma aliquota de $0,5 \mathrm{ml}$ de amostra contendo de 1,0 a 2,5 $\mu \mathrm{g}$ de Mo(VI) e adicionar $0,5 \mathrm{ml}$ de $\mathrm{HCl}$ concentrado (12N). Apōs agitar ligeiramente a solução e esperar alguns segundos adicionar $1,0 \mathrm{ml}$ de acetato de n-butila. Agitar durante vinte segundos, aproximadamente e centrifugar. Transferir a camada or gânica para um balão volumétrico de $10,0 \mathrm{ml}$ com o auxílio de uma pipeta de extração. Adicionar novamente $0,5 \mathrm{ml}$ do 
solvente à solução aquosa remanescente da passagem anterior. Agitar por alguns segundos e centrifugar, separando a fase orgānica e transferindo-a ao balão volumétrico. Esta passagem é repetida ainda uma vez.

Aos extratos, reunidos no balão volumétrico, adicionar $2,0 \mathrm{ml}$ da solução do reagente e completar o volu me com álcool etílico. Fazer a medida espectrofotométrica em $506 \mathrm{~nm}$ contra um branco obtido pelo mesmo procedimento. Utilizar a curva padrão da página 53. 


\section{3) ESTUDO DAS INTERFERENCIAS}

\section{3a) Estudo geral}

Os trabalhos de cluley ${ }^{(41)}$,. Schneider e San$\operatorname{del} 1^{(59)}$, Luke e Campbell ${ }^{(52)}$ indicaram que reagem com a fenilfluorona em meio aquoso os ions dos seguintes elementos: gâlio(III), titânio(IV), estanho(II e IV), arsênio (III e V), antimônio(III), bismuto(III), molibdênio(VI), ferro(III), Zircônio(IV), niobio(V), tântalo(V), Vanādio(V), germânio(III) e tungstênio(VI). Anious oxidantes fortes, como permanganato e cromato também interferem no método por destruirem o reagente.

$$
\text { Cluley (41) relaciona os seguintes íns como }
$$
não interferentes na determinação do germânio por' não reagirem com fenilfluorona: $\mathrm{NH}_{4}^{+}, \mathrm{Na}_{\mathrm{a}}^{+}, \mathrm{K}^{+}, \mathrm{L}_{\mathrm{i}}^{+}, \mathrm{Cu}^{+2}, \mathrm{Ag}^{+}$, $\mathrm{Be}^{+2}, \mathrm{Mg}^{+2}, \mathrm{Ca}^{+2}, \mathrm{Zn}^{+2}, \mathrm{Cd}^{+2}, \mathrm{Hg}^{(I I)}, \mathrm{Al}^{+3}, \mathrm{Cr}^{+3}, \mathrm{Mn}^{+2}$, $\mathrm{Fe}(\mathrm{II}), \mathrm{Co}^{+2}, \mathrm{Ni}^{+2}, \mathrm{BO}_{3}^{-3}, \mathrm{PO}_{3}^{-3} \mathrm{e} \mathrm{Cl}^{-}$.

Majundar e Savariar $(46,48)$, estudaram outro derivado da fluorona - 9 metil, 2-3-7 trihidioxi- 6 fluoro na como reagente analítico para determinação de Mo(VI) e Ti(IV) e mostraram que, além daqueles ions, constituem interferência em seus métodos, os seguintes ions, mesmo quan do presentes na solução em baixos teores: $F^{-}, \mathrm{PO}_{3}^{-3}, \mathrm{C}_{2} \mathrm{O}_{4}^{-2}$, $\mathrm{Al}^{+3}$ e $\mathrm{UO}_{2}^{+2}$. 
Por outro lado, Lilia Sant'Agostino (57).

na elaboração do método de determinação do germânio com fe nilfluorona em meio orgânico, após extração com metil-isobutil-cetona de soluções fortemente ácidas $(7,5 \mathrm{~N} \mathrm{HCl),} \mathrm{ve-}$ rificou que íons de gálio(III), estanho(IV), Arsênio(III e V), bismuto(III), tântalo(V) e titânio (IV) não constituíam interferências nas determinações ou por não reagirem com fenilfluorona em meio orgânico ou por não serem extraí dos nas conđições do método.

A fim de verificar a influência desses ions na determinação do Mo(VI) pelo método estabelecido neste trabalho, foram adicionados à solução aquosa os íons extra nhos na quantidade cem vezes superior ao molibdênio presen te. Somente no caso dos íons de títânio e tântalo usou-se teores menores devido à dificuldade de se preparar soluções mais concentradas. Para cada elemento foram feitas duạs ou mais determinações independentes.

Uma vez que este mētodo utiliza a reação em meio orgânico após extração com acetato de n-butila, vários ions que reagem com a fenilfluorona em meio aquoso, por não serem extraĩdos nas condições do mētodo, passam a não interferir na determinação.

Agrupou-se na tabela 15 os resultados obtidos da extração de soluções contendo $10 \mu \mathrm{g}$ de Mo e $1000 \mu \mathrm{g}$ dos ions que constituirram interferências e na tabela 16 reuniu-se os íons que não interferiram nas determinações . 
As provas foram executadas segundo o procedimento normal, partindo-se sempre de $1,0 \mathrm{ml}$ de fase aquosa.

O exame dos valores obtidos na tabela 15 mos tram que, com excessão do níobio(V) e do oxalato, as inter ferências provocam um aumento da absorbância das soluções, indicando com isso que os elementos são coextraidos com o Mo (VI) .

Por outro lado, o níobio(V), quando adiciona do na forma de niobato $\left(\mathrm{NbO}_{3}^{-}\right)$provoca uma queda na absorbân cia da solução final. Pôde-se constatar das experiênctas executadas que isto se deve ao fato de que o elemento, quando presente na quantidade de $1000 \mu \mathrm{g}$, precipita $\circ \mathrm{HNbO}_{3}$ ao se adicionar o ácido clorídrico, provocando coprecipita ção do Mo(VI). Quando se tem o Nb(V), na quantidade de $500 \mu \mathrm{g}$, verificou-se em vārios determinações que o mesmo pas sa a não interferir no mētodo como se vê na tabela 16.

o oxalato, sendo parcialmente extraído afeta - reagente, descorando as soluções.

As interferências do $\mathrm{Sn}($ IV), $\mathrm{Sb}$ (III), Ge (III) e $\mathrm{C}_{2} \mathrm{O}_{4}^{-2}$ devem ser eliminadas por um tratamento prëvio da amostra antes da execução do método. As outras interfêrencias são eliminadas ao se fazer uma modificação simples no procedimento usual, como é visto a seguir. 
A interferência devida ao tungstênio(VI) é estudada no capitulo seguinte.

\section{TABELA 15}

Determinação de Mo(VI) na presença de outros ions: Interferências

\begin{tabular}{|c|c|c|c|}
\hline \multicolumn{1}{|c|}{$\begin{array}{c}\text { Ions } \\
\text { Presentes }\end{array}$} & $\begin{array}{c}\text { Mo(VI) } \\
\text { Presente } \\
\mu g\end{array}$ & \multicolumn{2}{|c|}{ (506 nm) } \\
\hline & 10,0 & 0,440 & 0,440 \\
$1000 \mathrm{Ge}(\mathrm{III})$ & 10,0 & $>1$ & $>1$ \\
$1000 \mathrm{Fe}(\mathrm{III})$ & 10,0 & $>1$ & $>1$ \\
$1000 \mathrm{VO}-$ & 10,0 & 0,818 & 0,830 \\
$1000 \mathrm{Sn}(\mathrm{IV})$ & 10,0 & $>1$ & $>1$ \\
$1000 \mathrm{Sb}(\mathrm{III})$ & 10,0 & $>1$ & $>1$ \\
$1000 \mathrm{WO}_{4}^{-2}$ & 10,0 & $>1$ & $>1$ \\
$1000 \mathrm{NbO}_{3}^{-}$ & 10,0 & 0,355 & 0,380 \\
$1000 \mathrm{C}_{2}^{-2} \mathrm{O}_{4}^{-2}$ & 10,0 & 0,389 & 0,379 \\
\hline
\end{tabular}


TABELA 16

Determinação de Mo(VI) na presença de outros ions

\begin{tabular}{|c|c|c|c|c|}
\hline $\begin{array}{c}\text { Ions } \\
\text { Presentes } \\
\mu g\end{array}$ & $\begin{array}{c}\text { Mo (VI) } \\
\text { Presente } \\
\mu g\end{array}$ & \multicolumn{3}{|c|}{$\begin{array}{c}\text { Mo (VI) } \\
\text { encontrado } \\
\mu \mathrm{g}\end{array}$} \\
\hline & $10,0$. & & 10,0 & 10,0 \\
\hline $1000 \mathrm{~F}^{-}$ & 10,0 & & 9,83 & 9,85 \\
\hline $1000 \mathrm{HPO}_{4}^{-2}$ & 10,0 & & 10,1 & 10,2 \\
\hline $1000 \mathrm{NO}_{3}^{-}$ & 10,0 & & 9,85 & 9,80 \\
\hline $1000 \mathrm{SO}_{4}^{-2}$ & 10,0 & & 10,0 & 10,0 \\
\hline $1000 \mathrm{ClO}_{4}^{-}$ & 10,0 & & 10,1 & 10,1 \\
\hline $1000 \mathrm{UO}_{4}^{-2}$ & 10,0 & & 10,0 & 10,0 \\
\hline $1000 \mathrm{AsO}_{3}^{-3}$ & 10,0 & 9,90 & 10,0 & 10,0 \\
\hline $1000 \mathrm{AsO}_{4}^{-3}$ & 10,0 & 10,0 & 10,0 & 10,1 \\
\hline $1000 \mathrm{Bi}^{+3}$ & 10,0 & 10,3 & 10,1 & 10,2 \\
\hline $1000 \mathrm{zr}^{+4}$ & 10,0 & 9,85 & 9,95 & 10,0 \\
\hline $1000 \mathrm{Ga}^{+3}$ & 10,0 & 10,0 & 9,93 & 10,2 \\
\hline $1000 \mathrm{Al}^{+3}$ & 10,0 & 10,0 & 10,1 & 9,79 \\
\hline $200 \mathrm{Ti}(\mathrm{IV})$ & 10,0 & 10,2 & 10,2 & 10,1 \\
\hline $200 \mathrm{Ta}(\mathrm{V})$ & 10,0 & 10,1 & 10,2 & 10,3 \\
\hline $500 \mathrm{NbO}_{3}^{-}$ & 10,0 & 9,83 & 9,92 & 10,1 \\
\hline $\mathrm{ReO}_{4}^{-}$ & 10,0 & & 9,82 & 10,2 \\
\hline acetato & 10,0 & & 10,0 & 10,0 \\
\hline tartarato & 10,0 & & 10,1 & 10,2 \\
\hline citrato & 10,0 & & 10,0 & 10,3 \\
\hline
\end{tabular}


13b) Eliminação das Interferēncias de Fe (III) e V(V)

Os clorocomplexos de $\mathrm{Fe}(\mathrm{III})$ e $\mathrm{V}(\mathrm{V})$ que se formam pela adição de ácido clorídrico são extraídos em eter isopropílico e outros solventes oxigenados (58). o mes mo se verificou na extração com acetato de n-butila. Primeiramente pensou-se em eliminar a interferência do Fe(III) por sua separação prévia na forma de hidrōxido utilizando tanto hidrōxido de sódio quanto carbonato de sódio. Entretanto, além de se obter um volume final muito grande ocorreu coprecipitação do molibdênio não oferecendo o resultado esperado. Ainda procurou-se complexar o ferro(III) expe rimentando para isso o fluoreto, uma vez que Boch e Her $\underline{r}$ mann (64) indicaram baixa extração com eter etílico do composto formado. Entretanto, ou devido ao fato de se adicionar ácido clorídrico ou porque se utiliza acetato de n-butila, tambẻm ocorreu extração do ferro(III) num teor relativamente elevado. Ainda tentando utilizar o fluoreto como complexante pensou-se em, após extração do clorocomplexo, adicionar pequeno teor de fluoreto ao balão volumétrico an tes da adição do reagente. Os resultados não foram satisfa tórios uma vez que a solução aquosa do fluoreto afetou a estabilidade da solução final.

Finalmente, solucionou-se o problema optando pela redução do Ferro(III) a Ferro(II). Utilizou-se para isso o ácido ascórbico. 
Por outro lado a mesma solução foi utilizada para reduzir o Vanádio(V) a Vanádio(IV). A literatura indi $\mathrm{Ca}^{(65)}$ que redutores como $\mathrm{H}_{2} \mathrm{~S}, \mathrm{SO}_{2}, \mathrm{H}_{2} \mathrm{C}_{2} \mathrm{O}_{4}, \mathrm{FeSO}_{4}$ e mesmo álcool etílico reduzem o Vanádio(V) a sais de Vanádio(IV) sendo a reação mais răpida a quente. Entretanto, o ãcido ascórbico tambēm produz a reação, imediatamente, dando à solução coloração azul indicativa do vanádio (IV).

Procedimento: Ao tubo de extração contendo molibdênio(VI) e ferro (III) ou Vanádio(V) adiciona-se 0,1 ml (2 gotas) de ácido ascórbico 10\%. Aquece-se ligeiramente a solução, resfria-se à temperatura ambiente e adiciona-se $0,5 \mathrm{ml}$ de ảcido clorídrico concentrado procedendo à extração normal com acetato de n-butila. Na tabela 17 acham-se alguns resultados obtidos segundo este andamento.

TABELA 17

Determinação de Mo(VI) na presença de $\mathrm{Fe}(\mathrm{III})$ e $\mathrm{V}(\mathrm{V})$

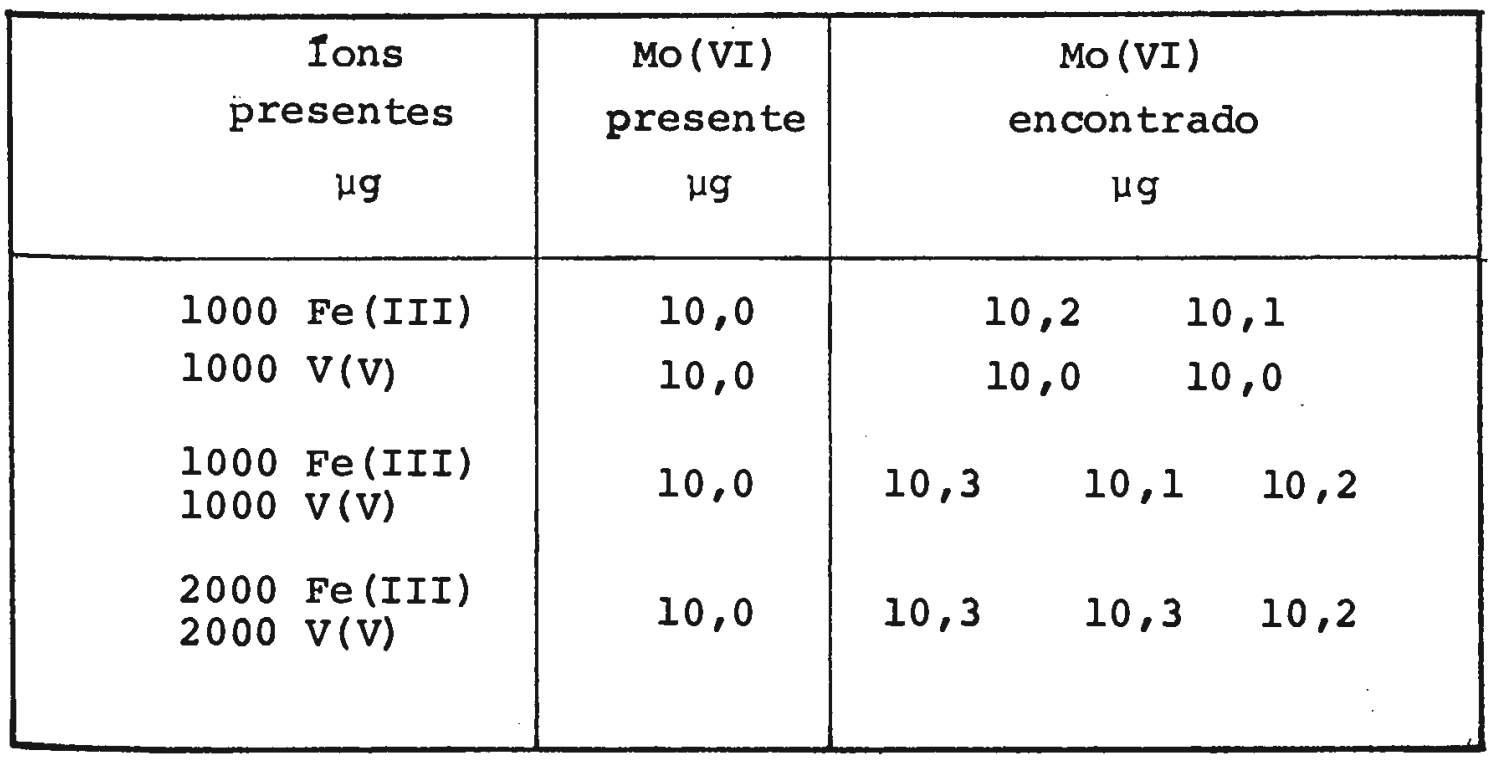


IV - ESTUDO DA SEPARAC̆̃̃O MOLIBDENIO-TUNGSTENIO

\section{1) CONSIDERAÇÕES GERAIS}

Como se pôde constatar na parte introdutória desta tese, ē da maior relevância o problema da separação molibdênio-tungstênio, especialmente do ponto de vista ana lítico, em que se procura determinar um dos elementos na presença de teores elevados do outro. Entretanto, apesar de ser grande o número de trabalhos relacionados com a determinação desses elementos são raros aqueles que chegam a solucionar satisfatoriamente o problema.

Neste sentido verificou-se que a extração de quelatos de molibdênio e.tungstênio de soluções aquosas por meio de solventes orgânicos tem-se constituído num meio amplamente utilizado para este fim ${ }^{(67-70)}$. No entanto, com respeito à extração desses elementos de sistemas "oxônio" ou na forma de pares iônicos, apesar da questão ter sido abordada sob diferentes aspectos foi possivel constatar certa carência de informações sistemāticas.

Assim, alguns pesquisadores se preocuparam em estudar a extractibilidade do molibdênio esclarecendo a natureza dos compostos extraíveis e os mecanismos de extra ção, sendo poucos os trabalhos de mesmo tipo como o tungstênio. 
Busev e colaboradores $(61,71,72)$ estudaram a extração do Mo(VI) de soluções cioríaricas com solventes oxigenados objtevando esclarecer a composição das espécies e a natureza da fase orgânica. Neilidow e Diamond ${ }^{(60)}$ determinaram a razão de distribuição do Mo(VI) em soluções àcidas entre vários solventes. Verificaram a influência de alguns fatores sobre a extratibilidade como temperatura , concentração dos ácidos e do elemento e ainda discutiram as possíveis fórmulas dos compostos extraídos. Golinsky (73) estudou a extratibilidade do Mo(VI) com tri-n-octilamina em função do tempo de contato da solução com o solvente, $\mathrm{pH}$ e fôrça iônica. Von $\mathrm{K}$. Arend ${ }^{(62)}$ estabeleceu a composição das espécies extraídas de $\operatorname{Cr}(\mathrm{III}), \mathrm{Mo}(\mathrm{VI}), \mathrm{W}(\mathrm{VI})$ e V(V) com fosfato de trin-butila de meio cloriarico.

Outros autores abordaram o problema do ponto de vista analítico encontrando condições de extração do mo libdēnio de outros elementos pela escolha adequada do solvente e do condicionamento do meio aquoso $(38,16,75-77)$. Er tretanto, com relação a estes trabalhos, apenas alguns pes quisadores solucionaram satisfatoriamente o problema da se paração. Mc.Kaverny e Freiser ${ }^{(18)}$ utilizaram acetilacetona como complexante e solvente ao mesmo tempo na extração do

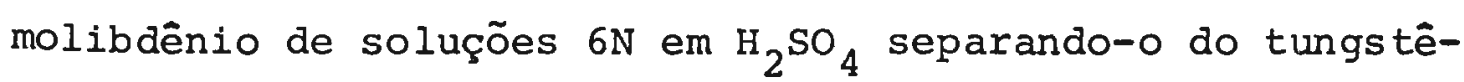
nio, Nazarenko e Shustova $(78,79)$ utilizaram àcido dietilcarbâmíco e ācido dietilditiocarbâmico com a mesma finalidade e Kiss e Hegedus ${ }^{(80)}$ extraíram molibdênio em condições específicas com fosfato de tri-n-butila. 
A ausência de uma sistemātica nestes trabalhos de separação fez que se propusesse investigar a extrạ tibilidade desses elementos em dois sistemas diferentes de extração. De um lado, empreerideu-se um estudo visando a utilização de sais de fosfônio, que têm. sido estudados de maneira ampla e sistemātica em nosso laboratório; de outro propôs-se aprofundar o estudo no sistema "oxônio", visando em ambos os casos uma extração seletiva.

A extratibilidade de sais de fosfônio de halogêno e pseudo-halogeno complexos de íns metālicos tem evidenciado que o comportamento desses compostos, em relação a diferentes tipos de solventes orgânicos, pode depender não só da natureza do complexante e do íon metālico, mas tambēm e, as vezes acentuadamente, de variações na estrutura do ion fosfônio. Em alguns casos, tais variações puderam proporcionar seletividade muito elevada, permitindo que se realizassem separações de interesse analítico ${ }^{(81-84)}$. Levi( ${ }^{(85)}$ e Senise ${ }^{(86)}$ mostraram que o aumento da cadeia alquilica do ion $\left\{\left(\mathrm{C}_{6} \mathrm{H}_{5}\right)_{3} \mathrm{PR}\right\}^{+}$pode ter acentuado efeito sobre a extratibilidade. Tais observações levaram a que se sintetizassem dois isômeros na sērie dos compostos do tipo $\left\{\left(\mathrm{C}_{6} \mathrm{H}_{5}\right)_{3} \mathrm{P}\left(\mathrm{C}_{4} \mathrm{H}_{10}\right)\right\}^{+}$e se fizesse um estudo da extra tibilidade do molibaênio(VI) e tungstênio(VI) com esses sais uma vez que os mesmos ainda não foram experimentados com os referidos elementos. 
2) ESTUDO DA EXTRATIBILIDADE DO MO(VI) E W(VI) COM OS SAIS DE FOSFÔNIO:

$$
\begin{aligned}
& \text { BROMETO DE TRIFENIL N-BUTILFOSFONIO } \\
& \text { BROMETO DE TRIFENIL ISO-BUTILFOSFONIO }
\end{aligned}
$$

Fez-se amplo estudo sistemätico com estes sais objetivando verificar a extratibilidade do Mo(VI) e $W(V I)$ em diferentes solventes. Procurou-se observar a influência da acidez sôbre a extração uma vez que este fator constituiu-se de enorme importância nos ensaios feitos anteriormente.

Em todos os testes procurou-se extrair $10 \mu \mathrm{g}$ do elemento na presença de $0,05 \mathrm{ml}$ de solução aquosa $1 \%$ do brometo de trifenil n-butilfosfônio e brometo de trifenil iso-butilfosfônio, em tres valores distintos de acidez aproximadamente 3,5 e $7 \mathrm{~N}$ em $\mathrm{HCl}$.

o estudo foi acompanhado, em cada caso, de extrações feitas com o respeito solvente, nas mesmas condi ções experimentais, mas na ausência do sal de fosfônio. Fez-se sempre uma única extração, mantendo igual proporção entre as fases. A fase orgânica, apōs extração, foi transferida para outro tubo ao qual se adicionou a fenilfluorona em solução alcoólica $0,02 \%$. Os resultados, avaliados pe la comparação visual das soluções finais tratadas com o rea gente colorimétrico são apresentados nas tabelas 18 e 19. 
o exame destes resultados mostrou que as soluções que continham os sais de fosfônio se comportaram praticamente do mesmo modo que as soluções que não os continham, para quase todos os solventes testados. Entretanto, fenetol e anisol observaram-se diferenças marcantes en tre a extratibilidade do Mo(VI) e do W(VI), surpreendentemente para os dois sais experimentados.

Em vista destes resultados passou-se a estu dar a viabilidade de uma separação utilizando-se os sais com os referidos solventes.

Entretanto, apesar das diferenças qualitativas observadas, quando se passou ao estudo quantitativo em que se investigou exaustivamente a influência de vários fá tores sobre o sistema, não foi possivel chegar a qualquer condição que permitisse uma separação efetiva.

$$
\text { Passou-se assim a estudar a extratibilidade }
$$
desses elementos, no sistema "oxônio", como será visto a se guir. 
Extratibilidade em solventes orgânicos de Mo(VI) e W(VI) em soluções aquosas conteudo ácido cloríarico e brometo de trifenil isobutil fosfônio. Reação em meio orgânico com fenilfluorona

\begin{tabular}{|c|c|c|c|c|c|}
\hline Solvente & $\begin{array}{l}\mathrm{HCl} \\
\mathrm{N}\end{array}$ & $\begin{array}{l}\text { Mo } \\
\left(\mathrm{P}^{+}\right)\end{array}$ & Mo & $\begin{array}{c}W \\
\left(P^{+}\right)\end{array}$ & W \\
\hline $\begin{array}{l}\text { acetato de } \\
\text { n-butila }\end{array}$ & $\begin{array}{l}3 \\
5 \\
7\end{array}$ & $\begin{array}{l}++ \\
++ \\
+++\end{array}$ & $\begin{array}{l}+ \\
++ \\
+++\end{array}$ & $\begin{array}{l}0 \\
0 \\
+\end{array}$ & $\begin{array}{l}0 \\
0 \\
+\end{array}$ \\
\hline $\begin{array}{l}\text { acetato de } \\
\text { isopropila }\end{array}$ & $\begin{array}{l}3 \\
5 \\
7\end{array}$ & $\begin{array}{l}+ \\
+++ \\
++\end{array}$ & $\begin{array}{l}+ \\
+++ \\
+\end{array}$ & $\begin{array}{l}0 \\
0 \\
+\end{array}$ & $\begin{array}{l}0 \\
0 \\
+\end{array}$ \\
\hline $\begin{array}{l}\text { acetato de } \\
\text { n-propila }\end{array}$ & $\begin{array}{l}3 \\
5 \\
7 \\
\end{array}$ & $\begin{array}{l}++ \\
++ \\
+ \\
\end{array}$ & $\begin{array}{l}++ \\
++ \\
+ \\
\end{array}$ & $\begin{array}{l}0 \\
0 \\
+\end{array}$ & + \\
\hline $\begin{array}{l}\text { acetato de } \\
\text { n-amila }\end{array}$ & $\begin{array}{l}3 \\
5 \\
7\end{array}$ & $\begin{array}{l}0 \\
+++ \\
++\end{array}$ & $\begin{array}{l}+ \\
+++ \\
++\end{array}$ & $\begin{array}{l}0 \\
0 \\
+\end{array}$ & $\begin{array}{l}0 \\
+\end{array}$ \\
\hline $\begin{array}{l}\text { acetato de } \\
\text { isoamila }\end{array}$ & $\begin{array}{l}3 \\
5 \\
7\end{array}$ & $\begin{array}{l}++ \\
++ \\
+\end{array}$ & $\begin{array}{l}++ \\
+++ \\
+\end{array}$ & $\begin{array}{l}0 \\
0 \\
+\end{array}$ & $\begin{array}{l}0 \\
+\end{array}$ \\
\hline $\begin{array}{l}\text { acetato de } \\
\text { benzila }\end{array}$ & $\begin{array}{l}3 \\
5 \\
7 \\
\end{array}$ & $\begin{array}{l}1 \\
++ \\
++ \\
\end{array}$ & $\begin{array}{l}1 \\
++ \\
++ \\
\end{array}$ & $\begin{array}{l}1 \\
0 \\
+ \\
\end{array}$ & $\begin{array}{r}1 \\
0 \\
+ \\
\end{array}$ \\
\hline $\begin{array}{l}\text { cloro acetato } \\
\text { de etila }\end{array}$ & $\begin{array}{l}3 \\
5 \\
7\end{array}$ & $\begin{array}{l}1 \\
1 \\
+\end{array}$ & $\begin{array}{l}1 \\
1 \\
+\end{array}$ & $\begin{array}{l}1 \\
1 \\
0\end{array}$ & $\begin{array}{l}1 \\
1 \\
0\end{array}$ \\
\hline $\begin{array}{l}\text { acetato de } \\
\text { isobutila }\end{array}$ & $\begin{array}{l}3 \\
5 \\
7\end{array}$ & $\begin{array}{l}+ \\
++ \\
++\end{array}$ & $\begin{array}{l}+ \\
+++ \\
+++\end{array}$ & $\begin{array}{l}0 \\
0 \\
0\end{array}$ & $\begin{array}{l}0 \\
0 \\
0\end{array}$ \\
\hline $\begin{array}{l}\text { di-n-amil } \\
\text { cetona }\end{array}$ & $\begin{array}{l}3 \\
5 \\
7 \\
\end{array}$ & $\begin{array}{l}+++ \\
++ \\
++ \\
\end{array}$ & $\begin{array}{l}+++ \\
++ \\
++ \\
\end{array}$ & $\begin{array}{l}+ \\
0 \\
0\end{array}$ & $\begin{array}{l}0 \\
0 \\
0\end{array}$ \\
\hline $\begin{array}{l}\text { metil iso-amil } \\
\text { cetona }\end{array}$ & $\begin{array}{l}3 \\
5 \\
7\end{array}$ & $\begin{array}{l}+ \\
1 \\
1\end{array}$ & $\begin{array}{l}+ \\
1 \\
1\end{array}$ & $\begin{array}{l}+ \\
1 \\
1\end{array}$ & $\begin{array}{l}+ \\
1 \\
1\end{array}$ \\
\hline
\end{tabular}


Continuação da TABELA 18

\begin{tabular}{|c|c|c|c|c|c|}
\hline Solvente & $\begin{array}{c}\mathrm{NCl} \\
\mathrm{N}\end{array}$ & $\begin{array}{l}\text { Mo } \\
\left(\mathrm{P}^{+}\right)\end{array}$ & Mo & $\begin{array}{c}W \\
\left(\mathrm{P}^{+}\right)\end{array}$ & $W$ \\
\hline $\begin{array}{l}\text { di-n-propil } \\
\text { cetona }\end{array}$ & $\begin{array}{l}3 \\
5 \\
7 \\
\end{array}$ & $\begin{array}{l}+++ \\
++ \\
+++\end{array}$ & $\begin{array}{l}++ \\
+++ \\
+++ \\
\end{array}$ & $\begin{array}{l}+ \\
+ \\
+ \\
\end{array}$ & $\begin{array}{l}+ \\
+ \\
+\end{array}$ \\
\hline $\begin{array}{l}\text { metil n-amil } \\
\text { cetona }\end{array}$ & $\begin{array}{l}3 \\
5 \\
7 \\
\end{array}$ & $\begin{array}{l}+++ \\
+++ \\
++\end{array}$ & $\begin{array}{c}+++ \\
+++ \\
++\end{array}$ & $\begin{array}{r}0 \\
0 \\
+\end{array}$ & $\begin{array}{l}0 \\
0 \\
+\end{array}$ \\
\hline $\begin{array}{l}\text { metil heptil } \\
\text { cetona }\end{array}$ & $\begin{array}{l}3 \\
5 \\
7\end{array}$ & $\begin{array}{l}+++ \\
++ \\
+++\end{array}$ & $\begin{array}{l}++ \\
++ \\
+++\end{array}$ & $\begin{array}{l}0 \\
0 \\
+\end{array}$ & $\begin{array}{l}0 \\
0 \\
+\end{array}$ \\
\hline $\begin{array}{l}\text { metil nonil } \\
\text { cetona }\end{array}$ & $\begin{array}{l}3 \\
5 \\
7 \\
\end{array}$ & $\begin{array}{l}+ \\
++ \\
+++\end{array}$ & $\begin{array}{l}+ \\
+++ \\
+++ \\
\end{array}$ & $\begin{array}{r}0 \\
0 \\
+ \\
\end{array}$ & $\begin{array}{r}0 \\
0 \\
+ \\
\end{array}$ \\
\hline $\begin{array}{l}\text { etil isoamil } \\
\text { cetona }\end{array}$ & $\begin{array}{l}3 \\
5 \\
7\end{array}$ & $\begin{array}{l}+++ \\
+++ \\
+++\end{array}$ & $\begin{array}{l}+ \\
+++ \\
+++\end{array}$ & $\begin{array}{r}0 \\
0 \\
+ \\
\end{array}$ & $\begin{array}{r}0 \\
0 \\
+ \\
\end{array}$ \\
\hline $\begin{array}{l}\text { metil n-hexil } \\
\text { cetona }\end{array}$ & $\begin{array}{l}3 \\
5 \\
7 \\
\end{array}$ & $\begin{array}{l}+ \\
+++ \\
++\end{array}$ & $\begin{array}{l}+ \\
+++ \\
++ \\
\end{array}$ & $\begin{array}{r}0 \\
0 \\
+ \\
\end{array}$ & $\begin{array}{r}0 \\
0 \\
+ \\
\end{array}$ \\
\hline $\begin{array}{l}\text { etil n-butil } \\
\text { cetona }\end{array}$ & $\begin{array}{l}3 \\
5 \\
7\end{array}$ & $\begin{array}{l}++ \\
++ \\
++\end{array}$ & $\begin{array}{l}++ \\
++ \\
++\end{array}$ & $\begin{array}{l}0 \\
0 \\
+\end{array}$ & $\begin{array}{r}0 \\
0 \\
+\end{array}$ \\
\hline $\begin{array}{l}\text { metil isopropil } \\
\text { cetona }\end{array}$ & $\begin{array}{l}3 \\
5 \\
7 \\
\end{array}$ & $\begin{array}{l}+++ \\
++ \\
+ \\
\end{array}$ & $\begin{array}{l}+++ \\
++ \\
+ \\
\end{array}$ & $\begin{array}{r}0 \\
+ \\
+ \\
\end{array}$ & $\begin{array}{r}0 \\
+ \\
+ \\
\end{array}$ \\
\hline ciclohexanona & $\begin{array}{l}3 \\
5 \\
7 \\
\end{array}$ & $\begin{array}{l}0 \\
1 \\
1\end{array}$ & $\begin{array}{l}0 \\
1 \\
1\end{array}$ & $\begin{array}{l}0 \\
1 \\
1\end{array}$ & $\begin{array}{l}0 \\
1 \\
1 \\
\end{array}$ \\
\hline $\begin{array}{l}\text { 2-butil } \\
\text { ciclohexanona }\end{array}$ & $\begin{array}{l}3 \\
5 \\
7 \\
\end{array}$ & $\begin{array}{l}++ \\
+++ \\
++\end{array}$ & $\begin{array}{l}++ \\
+++ \\
++\end{array}$ & $\begin{array}{r}0 \\
0 \\
+\end{array}$ & $\begin{array}{l}0 \\
0 \\
+ \\
\end{array}$ \\
\hline $\begin{array}{l}\text { 2-metil } \\
\text { ciclohexanona-l }\end{array}$ & $\begin{array}{l}3 \\
5 \\
7\end{array}$ & $\begin{array}{l}+++ \\
++ \\
+\end{array}$ & $\begin{array}{l}+++ \\
++ \\
+\end{array}$ & $\begin{array}{l}0 \\
+ \\
++\end{array}$ & $\begin{array}{l}0 \\
+ \\
++\end{array}$ \\
\hline
\end{tabular}


Continuação da TABELA 18

\begin{tabular}{|c|c|c|c|c|c|}
\hline Solvente & $\underset{\mathrm{N}}{\mathrm{NCl}}$ & $\begin{array}{c}\text { Mo } \\
\left(P^{+}\right)\end{array}$ & Mo & $\begin{array}{l}W \\
\left(P^{+}\right)\end{array}$ & W \\
\hline $\begin{array}{l}\text { 4-metil } \\
\text { ciclohexanona }\end{array}$ & $\begin{array}{l}3 \\
5 \\
7 \\
\end{array}$ & $\begin{array}{l}++ \\
++ \\
0 \\
\end{array}$ & $\begin{array}{l}++ \\
++ \\
0 \\
\end{array}$ & $\begin{array}{l}+ \\
+ \\
+ \\
\end{array}$ & $\begin{array}{l}+ \\
+ \\
+\end{array}$ \\
\hline $\begin{array}{l}\text { 3-metil } \\
\text { ciclohexanona }\end{array}$ & $\begin{array}{l}3 \\
5 \\
7\end{array}$ & $\begin{array}{l}+++ \\
++ \\
0\end{array}$ & $\begin{array}{l}++ \\
++ \\
0\end{array}$ & $\begin{array}{l}+ \\
++ \\
++\end{array}$ & $\begin{array}{l}+ \\
++ \\
++\end{array}$ \\
\hline $\begin{array}{l}\text { 2-propil } \\
\text { ciclohexanona }\end{array}$ & $\begin{array}{l}3 \\
5 \\
7\end{array}$ & $\begin{array}{l}+++ \\
+++ \\
++\end{array}$ & $\begin{array}{l}+++ \\
++ \\
++\end{array}$ & $\begin{array}{l}0 \\
+ \\
++\end{array}$ & $\begin{array}{l}0 \\
+ \\
++\end{array}$ \\
\hline n-octanol & $\begin{array}{l}3 \\
5 \\
7\end{array}$ & $\begin{array}{l}+++ \\
++ \\
0\end{array}$ & $\begin{array}{l}+++ \\
++ \\
0\end{array}$ & $\begin{array}{l}+ \\
+ \\
+\end{array}$ & $\begin{array}{l}+ \\
+ \\
+\end{array}$ \\
\hline n-heptanol & $\begin{array}{l}3 \\
5 \\
7\end{array}$ & $\begin{array}{l}+++ \\
+ \\
0\end{array}$ & $\begin{array}{l}+++ \\
+ \\
0\end{array}$ & $\begin{array}{l}+ \\
+ \\
+\end{array}$ & $\begin{array}{l}+ \\
+ \\
+\end{array}$ \\
\hline $\begin{array}{l}\text { álcool } \\
\text { isoamílico }\end{array}$ & $\begin{array}{l}3 \\
5 \\
7 \\
\end{array}$ & $\begin{array}{l}++ \\
+ \\
0 \\
\end{array}$ & $\begin{array}{l}++ \\
+ \\
0 \\
\end{array}$ & $\begin{array}{l}+ \\
+ \\
0 \\
\end{array}$ & $\begin{array}{l}+ \\
+ \\
0 \\
\end{array}$ \\
\hline $\begin{array}{l}\text { álcool } \\
\text { amílico }\end{array}$ & $\begin{array}{l}3 \\
5 \\
7\end{array}$ & $\begin{array}{l}++ \\
+ \\
0\end{array}$ & $\begin{array}{l}++ \\
+ \\
0\end{array}$ & $\begin{array}{l}+ \\
+ \\
0\end{array}$ & $\begin{array}{l}+ \\
+ \\
0\end{array}$ \\
\hline $\begin{array}{l}\text { álcool iso- } \\
\text { butilico }\end{array}$ & $\begin{array}{l}3 \\
5 \\
7\end{array}$ & $\begin{array}{l}++ \\
/ \\
/\end{array}$ & $\begin{array}{l}++ \\
/ \\
/\end{array}$ & $\begin{array}{l}+ \\
1 \\
1\end{array}$ & $\begin{array}{l}+ \\
1 \\
1\end{array}$ \\
\hline $\begin{array}{l}\text { àlcool ter- } \\
\text { butílico }\end{array}$ & $\begin{array}{l}3 \\
5 \\
7\end{array}$ & $\begin{array}{l}1 \\
1 \\
1\end{array}$ & $\begin{array}{l}1 \\
1 \\
1\end{array}$ & $\begin{array}{l}1 \\
1 \\
1\end{array}$ & $\begin{array}{l}1 \\
1 \\
1\end{array}$ \\
\hline ciclohexanona & $\begin{array}{l}3 \\
5 \\
7\end{array}$ & $\begin{array}{l}0 \\
0 \\
1\end{array}$ & $\begin{array}{l}0 \\
0 \\
1\end{array}$ & $\begin{array}{l}0 \\
0 \\
1\end{array}$ & $\begin{array}{l}0 \\
0 \\
1\end{array}$ \\
\hline $\begin{array}{l}\text { 2-metil } \\
\text { ciclohexanona }\end{array}$ & $\begin{array}{l}3 \\
5 \\
7\end{array}$ & $\begin{array}{l}+++ \\
++ \\
/\end{array}$ & $\begin{array}{l}+++ \\
++ \\
/\end{array}$ & $\begin{array}{l}+ \\
+ \\
/\end{array}$ & $\begin{array}{l}+ \\
+ \\
\end{array}$ \\
\hline
\end{tabular}


Continuação da TABELA 18

\begin{tabular}{|l|c|c|c|c|c|}
\hline \multicolumn{1}{|c|}{ Solvente } & $\begin{array}{c}\text { NCl } \\
\text { N }\end{array}$ & $\begin{array}{c}\text { Mo } \\
\left(P^{+}\right)\end{array}$ & Mo & $\begin{array}{c}\text { W } \\
\left(P^{+}\right)\end{array}$ & W \\
\hline dibenzil & 3 & $/$ & $/$ & $/$ & $/$ \\
eter & 5 & $/$ & $/$ & $/$ & $/$ \\
& 7 & $/$ & $/$ & $/$ & $/$ \\
\hline \multirow{3}{*}{ anisol } & 3 & 0 & 0 & 0 & 0 \\
& 5 & +++ & 0 & + & 0 \\
& 7 & +++ & 0 & + & 0 \\
\hline \multirow{3}{*}{ fenetol } & 3 & 0 & 0 & 0 & 0 \\
& 5 & ++ & 0 & 0 & 0 \\
benzeno & 7 & +++ & 0 & 0 & 0 \\
\hline \multirow{2}{*}{ tolueno } & 3 & 0 & 0 & 0 & 0 \\
& 5 & 0 & 0 & 0 & 0 \\
\hline fosfato de & 7 & 0 & 0 & 0 & 0 \\
tri-n-butila & 3 & 0 & 0 & 0 & 0 \\
& 5 & 0 & 0 & 0 & 0 \\
& 7 & 0 & 0 & 0 & 0 \\
\hline
\end{tabular}

convenções: $\quad \mathrm{p}^{+}=$soluções contendo $\circ$ fosfônio

$$
\begin{aligned}
0 & =\text { extração nula } \\
+ & =\text { extração de traços } \\
++ & =\text { extração regular } \\
+++ & =\text { extração boa } \\
/ & =\text { ocorreu miscibilidade das fases. }
\end{aligned}
$$


Extratibilidade em solventes orgânicos de Mo(VI) e W(VI) em soluções aquosas contendo ácido cloríarico e brometo de trifenil n-butil fosfônio. Reação em meio orgânico com fenilfluorona.

\begin{tabular}{|c|c|c|c|c|c|}
\hline Solvente & $\begin{array}{l}\mathrm{HCl} \\
\mathrm{N}\end{array}$ & $\begin{array}{l}\text { Mo } \\
\left(\mathrm{P}^{+}\right)\end{array}$ & Mo & $\begin{array}{l}\mathrm{W} \\
\left(\mathrm{P}^{+}\right)\end{array}$ & $\mathrm{W}$ \\
\hline $\begin{array}{l}\text { acetato de } \\
\text { n-butila }\end{array}$ & $\begin{array}{l}3 \\
5 \\
7 \\
\end{array}$ & $\begin{array}{l}++ \\
++ \\
++ \\
\end{array}$ & $\begin{array}{l}+ \\
++ \\
++ \\
\end{array}$ & $\begin{array}{r}0 \\
+ \\
+ \\
\end{array}$ & $\begin{array}{r}0 \\
+ \\
+ \\
\end{array}$ \\
\hline $\begin{array}{l}\text { acetato de iso- } \\
\text { propila }\end{array}$ & $\begin{array}{l}3 \\
5 \\
7 \\
\end{array}$ & $\begin{array}{l}+ \\
++ \\
++ \\
\end{array}$ & $\begin{array}{l}+ \\
++ \\
++ \\
\end{array}$ & $\begin{array}{l}0 \\
0 \\
+ \\
\end{array}$ & $\begin{array}{r}0 \\
0 \\
+ \\
\end{array}$ \\
\hline $\begin{array}{l}\text { acetato de } \\
\text { n-propila. }\end{array}$ & $\begin{array}{l}3 \\
5 \\
7 \\
\end{array}$ & $\begin{array}{l}++ \\
++ \\
+ \\
\end{array}$ & $\begin{array}{l}++ \\
++ \\
+ \\
\end{array}$ & $\begin{array}{l}0 \\
0 \\
+ \\
\end{array}$ & $\begin{array}{r}0 \\
0 \\
+ \\
\end{array}$ \\
\hline $\begin{array}{l}\text { acetato de } \\
\text { isoamila }\end{array}$ & $\begin{array}{l}3 \\
5 \\
7 \\
\end{array}$ & $\begin{array}{l}++ \\
+ \\
+ \\
\end{array}$ & $\begin{array}{l}++ \\
+ \\
+ \\
\end{array}$ & $\begin{array}{l}0 \\
0 \\
+ \\
\end{array}$ & $\begin{array}{r}0 \\
0 \\
+ \\
\end{array}$ \\
\hline $\begin{array}{l}\text { acetato de } \\
\text { n-amila }\end{array}$ & $\begin{array}{l}3 \\
5 \\
7 \\
\end{array}$ & $\begin{array}{l}+ \\
+ \\
++\end{array}$ & $\begin{array}{l}+ \\
+ \\
++ \\
\end{array}$ & $\begin{array}{l}0 \\
0 \\
0\end{array}$ & $\begin{array}{l}0 \\
0 \\
0\end{array}$ \\
\hline $\begin{array}{l}\text { metil n- } \\
\text { hexilcetona }\end{array}$ & $\begin{array}{l}3 \\
5 \\
7 \\
\end{array}$ & $\begin{array}{l}+++ \\
++ \\
++ \\
\end{array}$ & $\begin{array}{l}+++ \\
+++ \\
++\end{array}$ & $\begin{array}{l}0 \\
0 \\
++ \\
\end{array}$ & $\begin{array}{l}0 \\
0 \\
++ \\
\end{array}$ \\
\hline $\begin{array}{l}\text { metil iso- } \\
\text { propil cetona }\end{array}$ & $\begin{array}{l}3 \\
5 \\
7\end{array}$ & $\begin{array}{l}+++ \\
/ \\
1\end{array}$ & $\begin{array}{l}+++ \\
/ \\
/\end{array}$ & $\begin{array}{l}0 \\
1 \\
1\end{array}$ & $\begin{array}{l}0 \\
1 \\
1 \\
\end{array}$ \\
\hline $\begin{array}{l}\text { metil n- } \\
\text { amil cetona }\end{array}$ & $\begin{array}{l}3 \\
5 \\
7 \\
\end{array}$ & $\begin{array}{l}+ \\
++ \\
++ \\
\end{array}$ & $\begin{array}{l}+ \\
++ \\
++ \\
\end{array}$ & $\begin{array}{r}0 \\
+ \\
+ \\
\end{array}$ & $\begin{array}{r}0 \\
+ \\
+ \\
\end{array}$ \\
\hline $\begin{array}{l}\text { metil iso- } \\
\text { amil cetona }\end{array}$ & $\begin{array}{l}3 \\
5 \\
7\end{array}$ & $\begin{array}{l}+ \\
+ \\
+\end{array}$ & $\begin{array}{l}+ \\
+ \\
+\end{array}$ & $\begin{array}{l}0 \\
0 \\
+\end{array}$ & $\begin{array}{l}0 \\
0 \\
+\end{array}$ \\
\hline
\end{tabular}


Continuação da TABELA 19

\begin{tabular}{|c|c|c|c|c|c|}
\hline Solvente & $\begin{array}{c}\mathrm{NCl} \\
\mathrm{N}\end{array}$ & $\begin{array}{c}\text { Mo } \\
\left(\mathrm{P}^{+}\right)\end{array}$ & Mo & $\begin{array}{c}W \\
\left(P^{+}\right)\end{array}$ & W \\
\hline $\begin{array}{l}\text { di-n-propil } \\
\text { cetona }\end{array}$ & $\begin{array}{l}3 \\
5 \\
7 \\
\end{array}$ & $\begin{array}{l}+++ \\
+++ \\
+++\end{array}$ & $\begin{array}{l}+++ \\
+++ \\
+++\end{array}$ & $\begin{array}{l}+ \\
+ \\
+ \\
\end{array}$ & $\begin{array}{l}+ \\
+ \\
+\end{array}$ \\
\hline ciclohexanol & $\begin{array}{l}3 \\
5 \\
7 \\
\end{array}$ & $\begin{array}{l}0 \\
0 \\
1 \\
\end{array}$ & $\begin{array}{l}0 \\
0 \\
1 \\
\end{array}$ & $\begin{array}{l}0 \\
0 \\
1\end{array}$ & $\begin{array}{l}0 \\
0 \\
1\end{array}$ \\
\hline $\begin{array}{l}\text { 2-metil } \\
\text { ciclohexanol }\end{array}$ & $\begin{array}{l}3 \\
5 \\
7\end{array}$ & $\begin{array}{l}++ \\
+ \\
+ \\
\end{array}$ & $\begin{array}{l}++ \\
+ \\
+ \\
\end{array}$ & $\begin{array}{r}0 \\
0 \\
+ \\
\end{array}$ & $\begin{array}{l}0 \\
0 \\
+ \\
\end{array}$ \\
\hline ciclohexanona & $\begin{array}{l}3 \\
5 \\
7 \\
\end{array}$ & $\begin{array}{l}0 \\
+ \\
1 \\
\end{array}$ & $\begin{array}{l}0 \\
+ \\
1 \\
\end{array}$ & $\begin{array}{r}0 \\
+ \\
1 \\
\end{array}$ & $\begin{array}{r}0 \\
+ \\
1 \\
\end{array}$ \\
\hline $\begin{array}{l}\text { 2-metil } \\
\text { ciclohexanona }\end{array}$ & $\begin{array}{l}3 \\
5 \\
7 \\
\end{array}$ & $\begin{array}{l}+++ \\
++ \\
+ \\
\end{array}$ & $\begin{array}{l}+++ \\
++ \\
+ \\
\end{array}$ & $\begin{array}{r}0 \\
+ \\
+ \\
\end{array}$ & $\begin{array}{r}0 \\
+ \\
+ \\
\end{array}$ \\
\hline $\begin{array}{l}\text { álcool } \\
\text { n-butilico }\end{array}$ & $\begin{array}{l}3 \\
5 \\
7 \\
\end{array}$ & $\begin{array}{l}1 \\
1 \\
1 \\
\end{array}$ & $\begin{array}{l}1 \\
1 \\
1\end{array}$ & $\begin{array}{l}1 \\
1 \\
1\end{array}$ & $\begin{array}{l}1 \\
1 \\
1\end{array}$ \\
\hline $\begin{array}{l}\text { álcool } \\
\text { iso-butilico }\end{array}$ & $\begin{array}{l}3 \\
5 \\
7 \\
\end{array}$ & $\begin{array}{l}+ \\
1 \\
1\end{array}$ & $\begin{array}{l}+ \\
1 \\
1\end{array}$ & $\begin{array}{l}+ \\
1 \\
1\end{array}$ & $\begin{array}{l}+ \\
1 \\
1\end{array}$ \\
\hline $\begin{array}{l}\text { álcool } \\
\text { amílico }\end{array}$ & $\begin{array}{l}3 \\
5 \\
7 \\
\end{array}$ & $\begin{array}{l}++ \\
+ \\
+ \\
\end{array}$ & $\begin{array}{l}++ \\
+ \\
+ \\
\end{array}$ & $\begin{array}{l}+ \\
+ \\
+ \\
\end{array}$ & $\begin{array}{l}+ \\
+ \\
+ \\
\end{array}$ \\
\hline $\begin{array}{l}\text { álcool } \\
\text { iso-amílico }\end{array}$ & $\begin{array}{l}3 \\
5 \\
7 \\
\end{array}$ & $\begin{array}{l}++ \\
+ \\
0 \\
\end{array}$ & $\begin{array}{l}++ \\
+ \\
0 \\
\end{array}$ & $\begin{array}{r}0 \\
+ \\
0 \\
\end{array}$ & $\begin{array}{r}0 \\
+ \\
0 \\
\end{array}$ \\
\hline $\begin{array}{l}\text { metil iso-butil } \\
\text { carbinol }\end{array}$ & $\begin{array}{l}3 \\
5 \\
7 \\
\end{array}$ & $\begin{array}{l}+++ \\
++ \\
+\end{array}$ & $\begin{array}{l}++ \\
++ \\
+ \\
\end{array}$ & $\begin{array}{l}0 \\
0 \\
+\end{array}$ & $\begin{array}{r}0 \\
0 \\
+\end{array}$ \\
\hline benzeno & $\begin{array}{l}3 \\
5 \\
7\end{array}$ & $\begin{array}{l}0 \\
0 \\
0\end{array}$ & $\begin{array}{l}0 \\
0 \\
0\end{array}$ & $\begin{array}{l}0 \\
0 \\
0\end{array}$ & $\begin{array}{l}0 \\
0 \\
0\end{array}$ \\
\hline
\end{tabular}


Continuaçäo da TABELA 19

\begin{tabular}{|l|c|c|c|c|c|}
\hline Solvente & $\begin{array}{c}\text { HCl } \\
\text { N }\end{array}$ & $\begin{array}{c}\text { Mo } \\
\left(\mathrm{P}^{+}\right)\end{array}$ & Mo & $\begin{array}{c}\text { W } \\
\left(\mathrm{P}^{+}\right)\end{array}$ & $W$ \\
\hline \multirow{3}{*}{ tolueno } & 3 & 0 & 0 & 0 & 0 \\
& 5 & 0 & 0 & 0 & 0 \\
& 7 & 0 & 0 & 0 & 0 \\
\hline \multirow{3}{*}{ clorofórmio } & 3 & 0 & 0 & 0 & 0 \\
& 5 & 0 & 0 & 0 & 0 \\
anizol & 7 & 0 & 0 & 0 & 0 \\
\hline \multirow{3}{*}{ fenetol } & 3 & 0 & 0 & 0 & 0 \\
& 5 & ++ & 0 & 0 & 0 \\
\hline fosfato de & 7 & +++ & 0 & 0 & 0 \\
\hline tri-n-butila & 3 & 0 & 0 & 0 & 0 \\
& 5 & + & 0 & 0 & 0 \\
& 7 & ++ & 0 & 0 & 0 \\
\hline
\end{tabular}

convençöes: $\quad \mathrm{P}^{+}=$soluçōes contendo fosfônio

$0=$ extraçäo nula

+ = extração de traços

++ extração regular

+++ extração boa

$/$ = ocorreu miscibilidade das fases.

Nota da BCQ: No impresso não consta a página 78 
3) ESTUDO DA EXTRATIBILIDADE DO MO(VI) e W(VI) NO SISTEMA CLORIDRTCO E SULFORICO.

Na parte preliminar deste trabalho (cap. II) deu-se início à investigação do comportamento do tungstênio quando da extração do molibdênio de soluções clorídricas. Prossegue-se aquí, estudando a influência, sobre a ex tratibilidade, de íons cloreto, ainda no sistema clorídrico, quer pela variação na concentração de cloreto de sódio, quer pela variação na concentração do ãcido. Os melho res resultados foram obtidos com soluções $4 \mathrm{~N}$ em HCl e $4 \mathrm{~N}$ em cloreto de sódio, condição esta em que a solução alcança saturação com relação ao cloreto de sōdio.

Nestes ensaios utilizou-se a fenilfluorona como reagente colorimétrico em meio orgânico e procedeu-se a uma única extração mantendo a proporção $1: 1$ entre as duas fases. Na tabela 20 acham-se reunidos os resultados obtidos com vārios solventes. 
TABELA 20

Extratibilidade de Mo(VI) e W(VI) de soluções $4 \mathrm{~N}$ em HCl e $4 \mathrm{~N}$ em $\mathrm{NaCl}$ com diversos solventes.

$1 \mathrm{ml}$ fase aquosa: $1 \mathrm{ml}$ fase orgânica

\begin{tabular}{|l|c|c|c|c|}
\hline \multirow{2}{*}{ Solvente } & \multicolumn{4}{|c|}{ A (504 nm) } \\
\cline { 2 - 6 } & $\begin{array}{c}25 \mu \mathrm{g} \text { Mo } \\
\text { presente }\end{array}$ & $\begin{array}{l}25 \mu \mathrm{G} \text { W } \\
\text { presente }\end{array}$ & $\begin{array}{c}50 \mu \mathrm{g} \text { W } \\
\text { presente }\end{array}$ & $\begin{array}{l}250 \mu \mathrm{g} W \\
\text { presente }\end{array}$ \\
\hline acetato n-butila & 1,301 & 0,007 & 0,036 & 0,089 \\
acetato iso-amila & 1,222 & 0,013 & 0,059 & 0,155 \\
acetato iso-butila & 1,222 & 0,013 & 0,025 & 0,051 \\
etil n-butil cetona & 1,125 & 0,000 & 0,034 & 0,143 \\
acetato n-amila & 1,071 & 0,000 & 0,089 & 0,108 \\
\hline
\end{tabular}

Observa-se que o tungstênio, mesmo na propor ção de duas vezes em relação o teor de molibdênio tambēm é extraído.

Com o objetivo de encontrar condições nas quais a extratibilidade do Mo(VI) fosse a maior possivel e a do tungstênio praticamente nula, inclusive para teor cem vezes superior ao molibdênio, fez-se nova sērie de ensaios nos quais o ácido cloríarico foi substituido pelo àcido sulfürico num amplo estudo em que se variou as concentrações do ácido e do ín cloreto. Os melhores resultados foram obtidos quando se utilizou solução $6 \mathrm{~N}$ em $\mathrm{H}_{2} \mathrm{SO}_{4}$ e saturada em cloreto de sōdio. Verificou-se nestes ensaios que os íons cloreto tinham grande influência sobre a extra tibilidade do Mo(VI) . Assim, substituiu-se o cloreto de sọ 
dio inicialmente por cloreto de lítio e depois por brometo de sódio pois ambos apresentam maior solubilidade. Na tabe la 21 acham-se reunidos os resultados correspondentes às condições mais favorãveis alcançadas com os diferentes ele trólitos.

\section{TABELA 21}

Extratibilidade de Mo(VI) e W(VI) de soluções sulfúricas na presença de diversos eletrólitos. $1 \mathrm{ml}$ fase aquosa: $1 \mathrm{ml}$ fase orgânica

\begin{tabular}{|c|c|c|c|c|}
\hline \multirow[b]{2}{*}{ meio aquoso } & \multicolumn{4}{|c|}{ A $(504 \mathrm{~nm})$} \\
\hline & $\begin{array}{l}25 \mu \mathrm{g} \text { Mo } \\
\text { presente }\end{array}$ & $\begin{array}{l}25 \mu \mathrm{g} \\
\text { presente }\end{array}$ & $\begin{array}{c}50 \mu g \mathrm{~W} \\
\text { presente }\end{array}$ & $\begin{array}{l}250 \mu \mathrm{g} \quad \mathrm{W} \\
\text { presente }\end{array}$ \\
\hline $\begin{array}{l}\mathrm{H}_{2} \mathrm{SO}_{4} 6 \mathrm{~N} \\
\mathrm{NaCl} \text { Sat }\end{array}$ & 1,097 & 0,007 & 0,020 & 0,046 \\
\hline $\begin{array}{l}\mathrm{H}_{2} \mathrm{SO}_{4} \quad 0,5 \mathrm{~N} \\
\mathrm{LiCl} 8 \mathrm{~N}\end{array}$ & 1,347 & 0,004 & 0,137 & ----- \\
\hline $\begin{array}{l}\mathrm{H}_{2} \mathrm{SO}_{4} 0,5 \mathrm{~N} \\
\mathrm{NaBr} \text { sat }\end{array}$ & 0,432 & 0,000 & 0,000 & 0,004 \\
\hline
\end{tabular}

Quando se procedeu à extração a partir de so luções saturadas em brometo de sōdio e $0,5 \mathrm{~N}$ em $\mathrm{H}_{2} \mathrm{SO}_{4}$ obser - vou-se que $\circ W(V I)$ não foi extraído embora o Mo(VI) apresentasse valor mals baixo em absorbância. Este resultado sugeriu um aprofundamento na pesquisa no sentido de verifi car se aquelas condições levavam à uma extração quantitatí va e seletiva do molibdênio. 
Para tanto, procurou-se extrair a espēcie da solução mediante tres extrações consecutivas $(1+1+1 \mathrm{ml}$ de acetato de n-butila) e para diferentes concentrações de mo libdato. Os resultados obtidos mostraram que embora a extração fosse proporcional à concentração das espécie extraída não era rigorosamente quantitativa.

Em continuidade a este estudo procurou-se ex plorar outros fatores que poderiam influir sobre a extração. Assim, observou-se a extratibilidade dos dois elementos nos sistemas clorídrico e sulfúrico em misturas de sol ventes oxigenados com não polares em diferentes proporções como benzeno e tolueno. Verificou-se nestes ensaios a dimi nuição da extratibilidade de maneira acentuada.

4) INFLUENCIA DO ÁCIDO CITRICO NA EXTRATIBILIDADE DO Mo(VI) E W(VI).

Voltando à extração do molibdênio nas condições estabelecidas pelo método analítico, ou seja, a partir de soluções $6 \mathrm{~N}$ em ãcido cloríarico com acetato de $\mathrm{n}$-bu tila, procurou-se verificar a influência de complexantes como tartarato, oxalato e citrato. A presença de tartarato não influiu praticamente no comportamento dos dois elementos. o oxalato, como jâ visto anteriormente, sendo extraído em baixo teor alterou a cor do reagente. Entretanto, o 
ácido cítrico afetou a extração dos dois elementos e, mais acentuadamente a do tungstênio. Isto levou à idéia de estu dá-lo mais pormenorizadamente.

Aliās, alguns pesquisadores jā utilizaram com êxito o ácido cítrico e o ácido oxálico como complexan tes para o tungstênio em melo aquoso em determinações colo rimētricas do molibdênio nas quais o primeiro constituía interferência.

Em 1943 Grimaldi e Wells ${ }^{(6)}$ utilizaram citra to de amônio com essa finalidade na determinações do molib dênio pelo método do tiocianato. Lazarev (8) utilizou tanto oxalato como citrato para aperfelçoar o mesmo método.Na clássica determinação do molibdênio com ditiol desenvolvida por Brickford e colaboradores ${ }^{(20)}$ usou-se ácido cítrico para evitar a reação do tungstênio com o complexante. o mesmo foi utilizado por Anokhina e Agrinskaya ${ }^{(87)}$. Nos tra balhos de Shustova(79) e Bankowskis e colaboradores (35) são utilizados respectivamente ácido cítrico e oxálico afim de manter o tungstênio em solução enquanto os complexos de molibdênio com dietilditiocarbamato e tioxina, respectivamente, são extraídos por meio de solventes.

Assim, iniciou-se os estudos verificando o efeito da concentração do äcido cítrico sobre a extratibilidade dos dois elementos. Verificou-se que existe um limi te de concentração do ācido (quando se adiciona 0,05 ml de solução $10 \%$ ao tubo de extração) acima do qual a extratibî 
dade de $10 \mu \mathrm{g}$ do molibdênio é prejudicada. E, nestas condições a de $100 \mu$ g do tungstênio diminui sem ser totalmente impedida. Em vista disso, persou-se em.verificar a possibj. lidade de separação dos elementos atravez de extração, reversão à fase aquosa e posterior reextração nas mesmas condições, adicionando-se, nas duas etapas de extração, o ācido cítrico na quantidade permitida. Como já foi visto anteriormente (pg 49) a reversão leva a uma recuparação ótima do molibdênio na extração subsequente.

Realmente, utilizando-se este procedimento foi possível determinar o Mo(VI) na presença de $100 \mu \mathrm{g}$ de $W(V I)$. Procurou-se aumentar o limite de tolerância para $200 \mu g$ de $W(V I)$, entretanto o mesmo passa a ser extraído na segunda passagem da reversão. Alguns resultados estão reunidas na tabela 22 .

TABELA 22

Determinação de Mo(VI) na presença de W(VI) Extração de soluções contendo ācido cítrico Método da reversão

\begin{tabular}{|c|c|c|}
\hline $\begin{array}{c}\text { Mo(VI) } \\
\text { presente } \\
\mu \mathrm{g}\end{array}$ & $\begin{array}{c}\text { W(VI) } \\
\text { adicionado } \\
\mu \mathrm{g}\end{array}$ & $\begin{array}{c}\text { Mo(VI) } \\
\text { encontrado } \\
\mu \mathrm{g}\end{array}$ \\
\hline 0,5 & 100 & 4,82 \\
10,0 & 100 & 9,80 \\
15,0 & 100 & 14,7 \\
\hline
\end{tabular}


Procedimento: Ao tubo de extração contendo $0,5 \mathrm{ml}$ da amostra adiciona-se $0,05 \mathrm{ml}$ de solução 108 em ácido cítrico e $0,5 \mathrm{ml}$ de àcido clorídrico concentrado. Procede-se à extra ção e reversão à fase aquosa nas condições jā indicadas na pg. 49 . Antes da extração subsequente, adiciona-se novamen te $0,05 \mathrm{ml}$ de solução 108 do ácido cítrico e 0,5 ml de ácí do cloridrico concentrado. Extrai-se e determina-se o molibdênio seguindo o andamento normal.

5) INFLUENCIA DO ÁCIDO CITRICO NAS REAÇÕES DE MO(VI) E W(VI) COM FENILFLUORONA EM MEIO ORGANICO.

Insistindo na idéia de aproveitar ácido cítrico que, pelo exame dos trabalhos anterlormente referidos, parece complexar mais fortemente com $\circ W(V I)$ do que com o Mo(VI) em meio aquoso, pensou-se em inibir sua rea ção com a fenilfluorona em meio orgânico, pela adição do ācldo.

Assim, iniciou-se um pequeno estudo qualitativo adicionando-se aos extratos orgânicos quantidades variāveis de ãcido cítrico em solução alcoólica após a adição do reagente. o ácido cítrico não alterou a cor do reagente nem da solução contendo o complexo de molibdênio. En tretanto, as amostras obtidas da extração deste elemento na presença de 10 vezes o teor em tungstênio, mostraram, 
surpreendentemente, um descoramento pronunciado da solução. Este fato conduziu ao estudo quantitativo do fenômeno.

6) DETERMINAÇÃO DE MOLIBDENIO NA PRESENÇA DE TUNGSTENIO EM MEIO ORGANICO CONTENDO ACIDO CITRICO.

Procedeu-se a duas séries de extrações para duas concentrações diferentes de molibdênio, adicionando aos balões volumétricos contendo os extratos orgânicos, vo lumes variāveis de ãcido cítrico em solução alcoólica 1 . Acrescentou-se em seguida o reagente e completou-se o volu me com álcool absoluto. (tabela 23). Em outros ensaios extraiu-se o molibdênio de soluções contendo tungstênio e ob servou-se o efeito da adição do ácido cítrico (tabela 24). 
TABELA 23

Efeito da concentração de ácido cítrico sôbre a reação Mo - fenilfluorona em meio orgânico

\begin{tabular}{|c|c|c|}
\hline \multirow{2}{*}{$\begin{array}{l}\text { volume de } \\
\text { ácido cítrico, sol. } \\
\text { lo ãlcool, adicionado }\end{array}$} & \multicolumn{2}{|c|}{ A $(506 \mathrm{~nm})$} \\
\hline & $\begin{array}{c}\text { Mo } \\
1,0 \mu \mathrm{g} / \mathrm{ml}\end{array}$ & $\begin{array}{c}\text { Mo } \\
2,0 \mu \mathrm{g} / \mathrm{ml}\end{array}$ \\
\hline & 0,445 & 0,882 \\
\hline $0,05 \mathrm{ml}$ & 0,450 & 0,885 \\
\hline $0,1 \mathrm{ml}$ & 0,448 & 0,883 \\
\hline $0,2 \mathrm{ml}$ & 0,448 & 0,887 \\
\hline 0,4 & 0,430 & 0,830 \\
\hline $0,8 \mathrm{ml}$ & 0,398 & 0,745 \\
\hline
\end{tabular}

TABELA 24

Efeito da presença de ācido cítrico sobre a reação W - fenilfluorona em meio orgânico

\begin{tabular}{|c|c|c|}
\hline & \multicolumn{2}{|c|}{ A $(506 \mathrm{~nm})$} \\
\hline & $10 \mu \mathrm{g}$ MO & $\begin{array}{rl}10 \mu \mathrm{g} & \text { Mo } \\
100 \mu \mathrm{g} & \mathrm{W}\end{array}$ \\
\hline $\begin{array}{l}\text { solução sem } \\
\text { ācido cítrico }\end{array}$ & 0,445 & 0,721 \\
\hline $\begin{array}{l}\text { soluções conten- } \\
\text { do } 0,1 \mathrm{ml} \text { de āci } \\
\text { do cítrico } 18 \mathrm{em} \\
\text { álcool. }\end{array}$ & $\begin{array}{l}0,445 \\
0,443 \\
0,438\end{array}$ & $\begin{array}{l}0,444 \\
0,434 \\
0,437\end{array}$ \\
\hline
\end{tabular}


Os resultados mostram que efetivamente o áci do cítrico inibe a reação da fenilfluorona com o tungstênio permitindo a determinação de molibdênio. o äcido cítrí co passa a intervir na reação do molibdênio somente quando se adiciona acima de $0,4 \mathrm{ml}$ de solução alcoölica 18 .

Procedimento: Após extração do molibdênio como jã estabele cido no método, adiciona-se $0,1 \mathrm{ml}$ de solução alcoólica 18 em ācido cítrico ao balão volumētrico de $10 \mathrm{ml}$ antes da adição de $2,0 \mathrm{ml}$ do reagente. Completa-se o volume com ālcool etílico absoluto e faz-se a leitura contra um branco obtido da mesma maneira em $506 \mathrm{~nm}$.

Na tabela 25 acham-se reunidos os dados obti dos na determinação de molibdênio quando extraído de soluções contendo teores variāveis de tungstēnio. Como se ol.userva, as determinações do molibdênio na presença de 50 ve zes o seu teor em tungstênio acarretam um erro de apenas 2‡. Para teores maiores de tungstênio forma-se $\mathrm{H}_{2} \mathrm{WO}_{4}$ quando se adiciona ācido-clorídrico concentrado ao tubo de extração e o molibdēnio fica retido por coprecipitação dando resultados mais baixos. 


\section{TABELA 25}

Determinação de Mo(VI) na presença de W(VI) em meio orgânico contendo ácido cítrico pela reação com fenilfluorona

\begin{tabular}{|c|c|c|c|c|}
\hline $\begin{array}{c}\text { W(VI) } \\
\text { adicionado } \\
\mu \mathrm{g}\end{array}$ & $\begin{array}{c}\text { Mo(VI) } \\
\text { presente } \\
\mu \mathrm{g}\end{array}$ & \multicolumn{3}{|c|}{$\begin{array}{c}\text { Mo(VI) } \\
\text { encontrado } \\
\mu \mathrm{g}\end{array}$} \\
\hline & 10,0 & 10,0 & 10,0 & 10,0 \\
10 & 10,0 & 9,95 & 9,95 & 9,90 \\
100 & 10,0 & 9,98 & 9,93 & 9,95 \\
200 & 10,0 & 9,87 & 9,85 & 9,78 \\
500 & 10,0 & 9,88 & 9,98 & 9,95 \\
1000 & 10,0 & 9,25 & 9,30 & 9,20 \\
\hline
\end{tabular}




\section{V - Estudo do Complexo Molibdênio-Fenilfluorona}

Com o objetivo de obter maiores esclarecimen tos sôbre a natureza do produto da reação entre o molibdênio e a fenilfluorona procurou-se preparar o complexo e es tudā-lo em soluções e no estado sōlido.

1) PREPARAÇÃO DO COMPOSTO MOLIBDENIO-FENILFLUORONA

Adaptaram-se neste caso as indicações de Lilia Sant'Agostinho (57) utilizadas na preparação de complexo similar com o germânio. Apenas foi necessārio diminuir a acidez indicada naquele trabalho, bem como usar excesso de molibdato com relação ao complexante.

$0,100 \mathrm{~g}$ de fenilfluorona foram dissolvidos, a quente, em $250 \mathrm{ml}$ de álcool etílico contendo 0,5 ml de ácí do sulfúrico concentrado. A essa solução adicionou-se 250 ml de āgua e $50 \mathrm{ml}$ de uma solução de molibdato de sódio contendo $50 \mathrm{mg}$ em molibdênio. Após 24 horas o precipitado vermelho formado foi filtrado em placa porosa e lavado com três porções de água. Adicionaram-se sôbre o precipitado algumas gotas de acetona deixando-se secar ao ar e em seguida em dessecador a vácuo sôbre cloreto de cálcio. 
2) ESTUDO DA SOLUBILIDADE DO COMPOSTO

Fez-se um estudo qualitativo da solubilidade do composto em vārios solventes orgânicos, tanto polares como não polares e verificou-se que a mesma ē maior em ace tatos e centonas, diminuindo para ālcoois e finalmente não se dissolvendo praticamente nada em solventes não polares. A coloração das soluções que se obteve variou desde o castanho escuro ao rosa claro. Tabela 26.

Destes solventes escolheram-se aqueles nos quais a solubilidade foi maior e determinou-se os espectros de absorção. Figuras 8 a 18 .

Conclui-se do exame desses espectros que existem pequenas diferenças na região de máxima absorbância - entre 480 e $510 \mathrm{~nm}$. 
TABELA 26

Solubilidade do composto molibdênio-fenilfluorona em diversos solventes

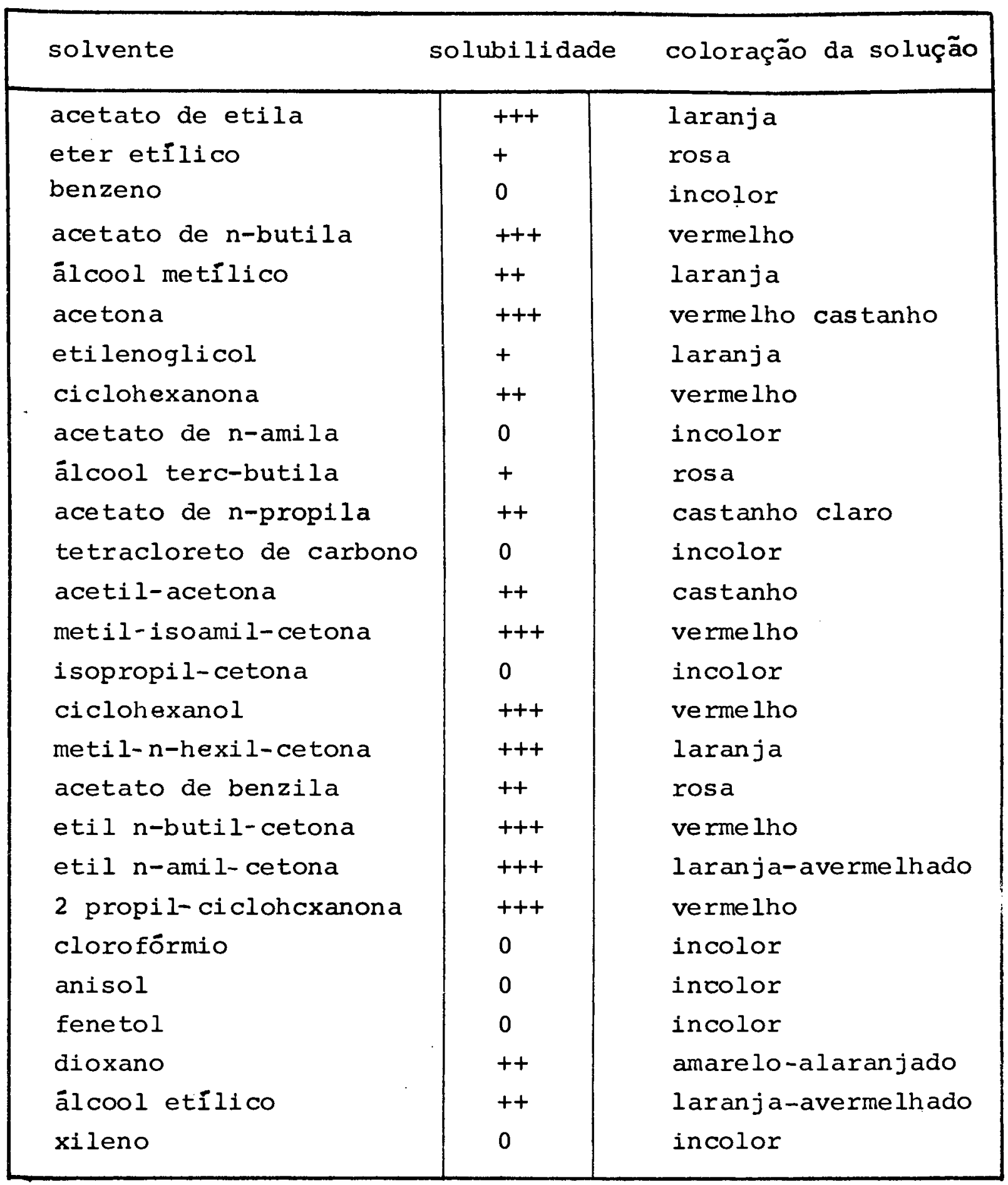

$$
\begin{array}{cll}
\text { Convenção } & +++ & \text { muito solúvel } \\
++ & \text { solūvel } \\
+ & \text { traços } \\
0 & \text { insolūvel }
\end{array}
$$



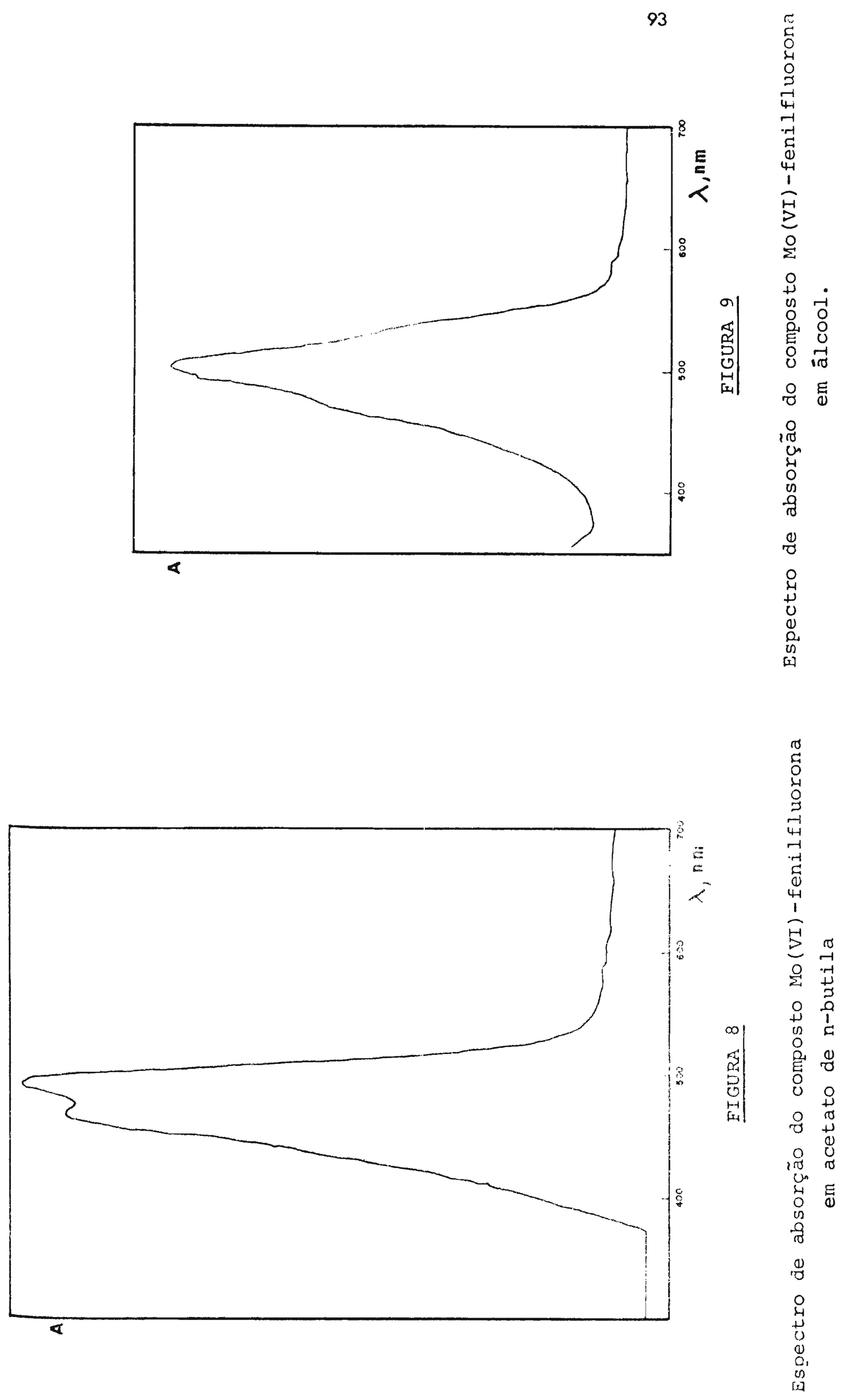


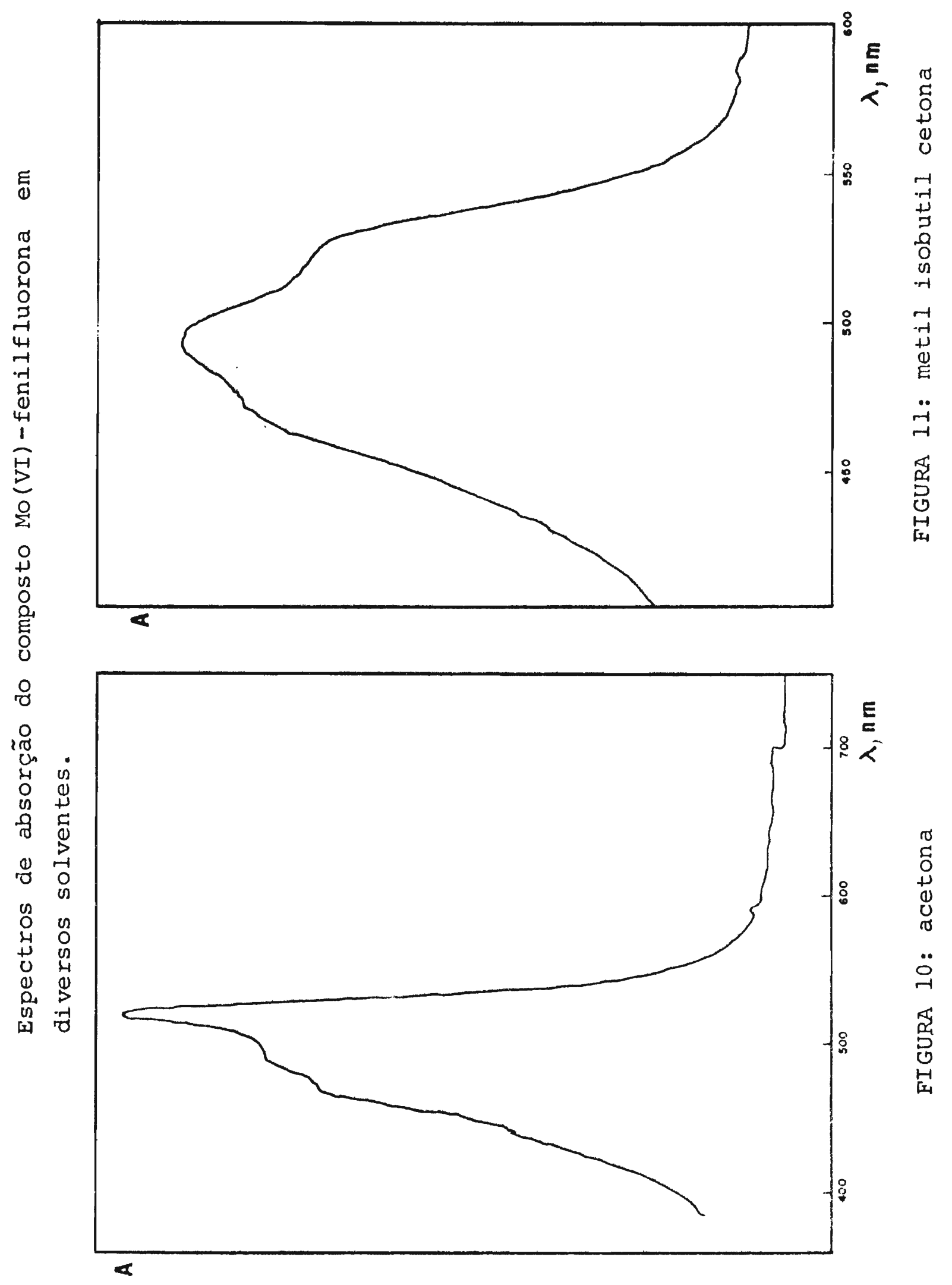


Espectros de absorção do composto Mo(VI)-fenilfluorona em diversos solventes.

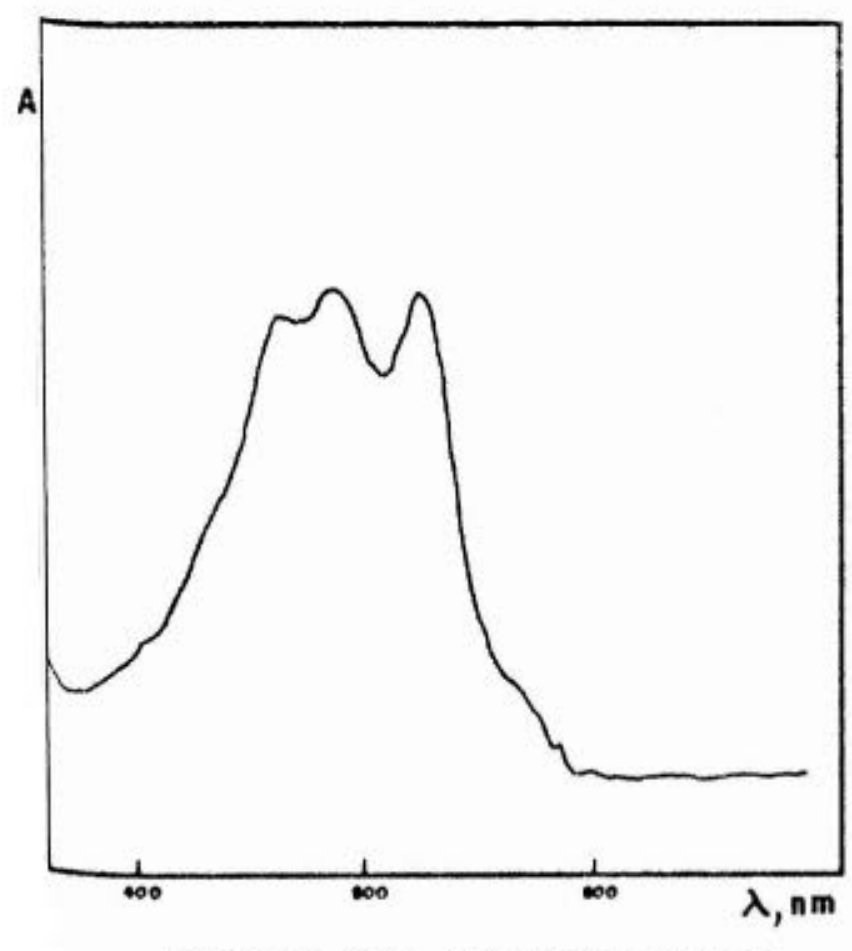

FIGURA 12: ciclohexanona

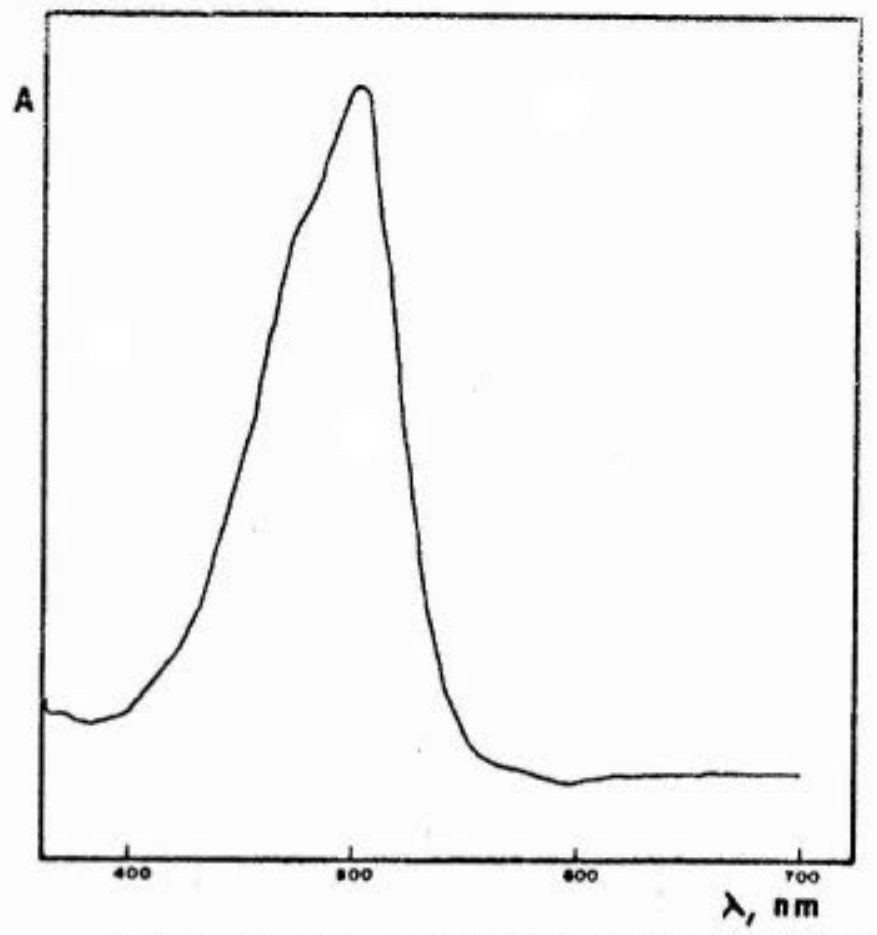

FIGURA 13: acetato de n-propila

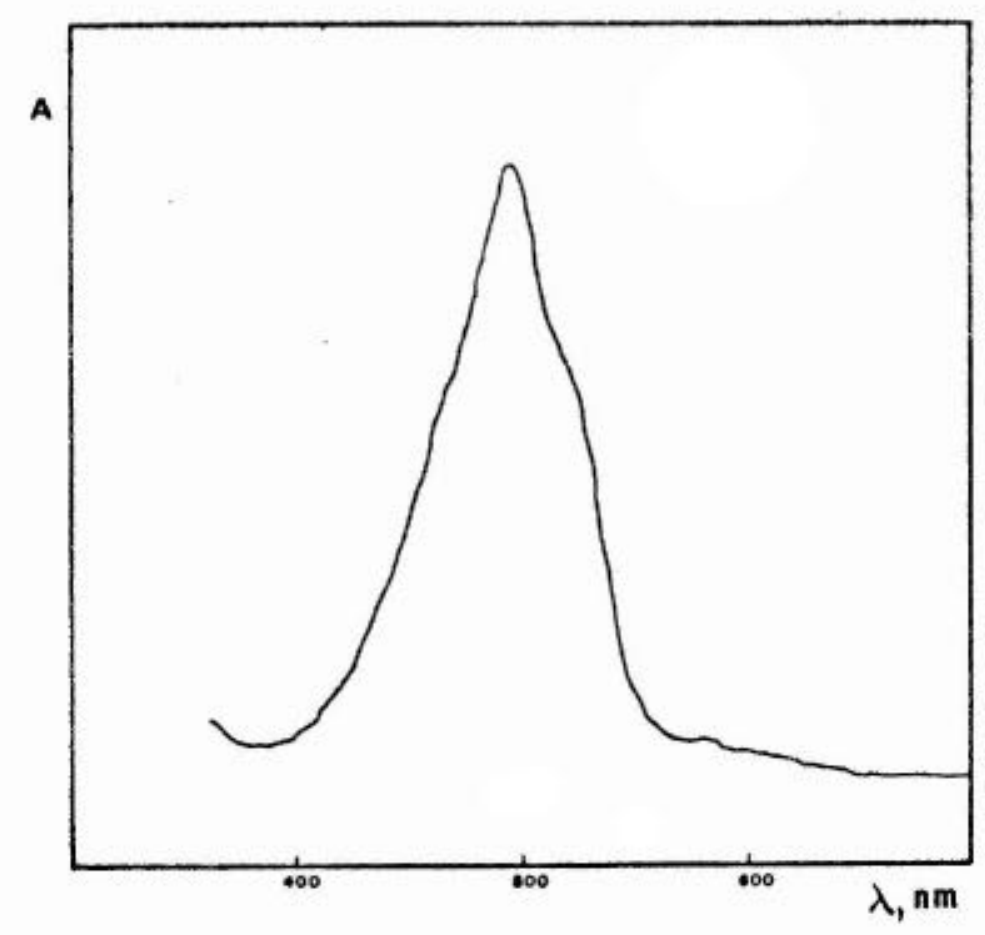

FIGURA 14: ālcool metílico 


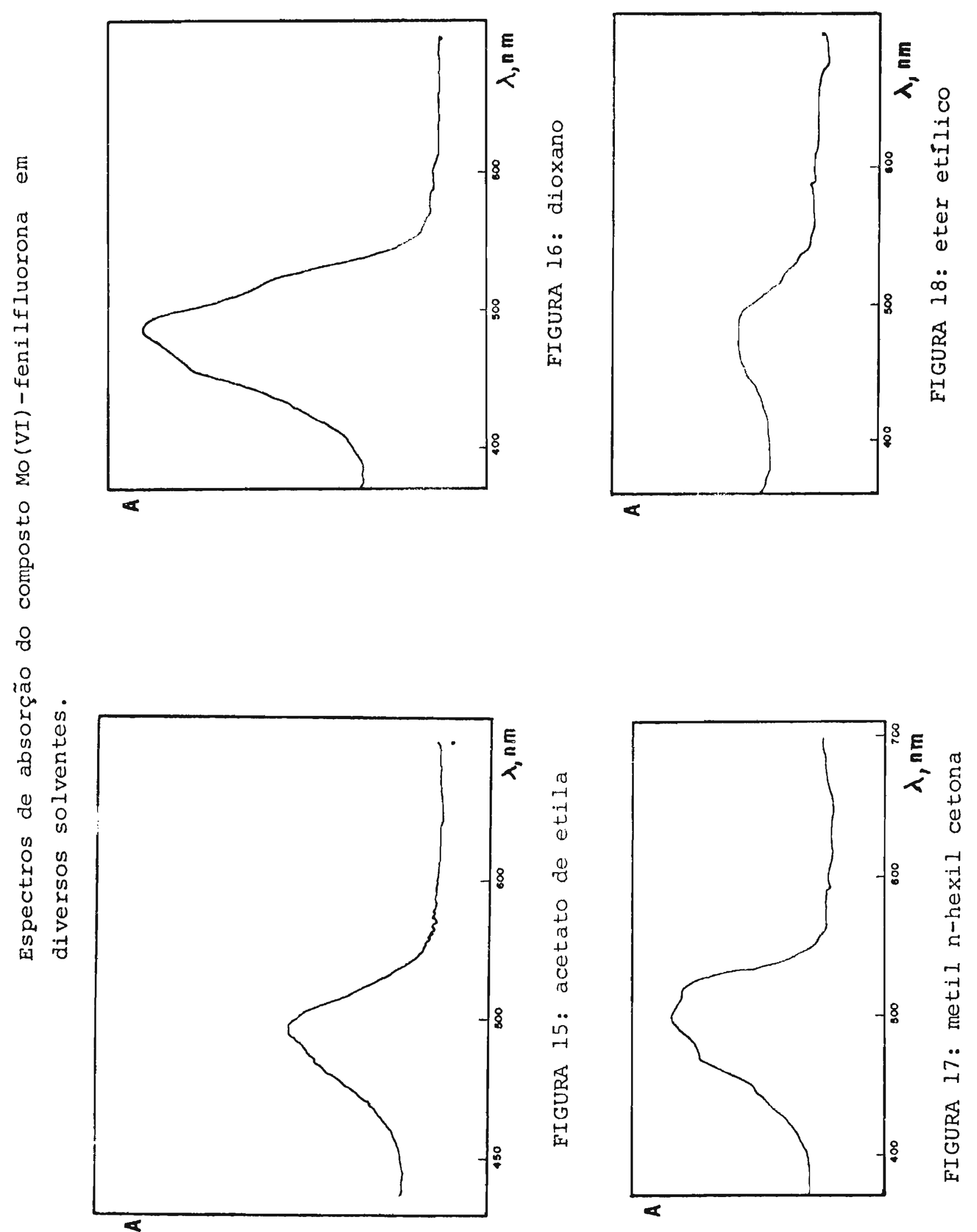


Do ponto de vista que interessa particularmente neste trabalho, observa-se que os espectros em älcool etilico e acetato de n-butila apresentam um máximo em 502 e 495 nm respectivamente. Entretanto, nas condiçōes ex perimentais em que o método de determinação é desenvolvido, o espectro que se obtem (ver figura 3 - pg 39 ) apresenta máximo entre 502 e 506 nm dependendo justamente da proporção entre o álcool e o solvente. Considere-se ainda que no método de determinação tem-se certo teor de ácido clorídrí co que é extraído e que acarreta alguma alteração na cor da solução. Assim, para efeito de comparação, procurou-se desenvolver a cor exatamente nas condições do método. 


\section{3) ESTUDO COMPARATIVO DOS ESPECTROS EM MEIO ORGÃNICO}

o composto molibdênio-fenilfluorona preparado foi dissolvido numa solução idêntica àquela em que a reação entre o molibdênio e o reagente ocorre no método analitico.

Agitaram-se $10 \mathrm{ml}$ de acetato de n-butila com $10 \mathrm{ml}$ de $\mathrm{HCl}(1: 1)$ e extraiu-se a camada orgânica, após centrifugação, transferindo-a para um balão volumétrico de $100 \mathrm{ml}$. Com a solução aquosa remanescente repetiu-se o processo anterior duas vêzes, reunindo-se os extratos no balão. Neste dissolveu-se aproximadamente lmg do complexo e completou-se o volume com álcool. Fez-se um branco da mesma maneira. A dissolução completa do composto foi obtida apōs vigorosa agitação da solução e seu ligeiro aquecimento. Com o mesmo procedimento se preparou outra solução con tendo aproximadamente $0,5 \mathrm{mg}$ do composto.

Nas figuras 19 e 20 são comparados os espectros dessas soluções (I e II da figura 20) com os espectros de duas soluções (I e II da figura 19) obtidas pelo mētodo analítico quando determinados contra o branco.

Na figura 20 tem-se o espectro diferencial (III) do composto dissolvido numa solução idêntica àquela em que a reação ocorre, contendo o reagente na proporção em que o mesmo se encontra no método analítico. Seguiu-se 
- procedimento anterior adicionando $20 \mathrm{ml}$ do reagente ao balão de $100 \mathrm{ml}$ e completando-se o volume com ālcool etílí co. Fez-se um branco da mesma maneira.

Embora este estudo tenha carăter apenas qualitativo, tendo-se em vista as dificuldades de se pesar teores tão pequenos do complexo, é possível concluir, pela comparação dos espectros, que o complexo preparado è o mes mo que se forma na reação em meio orgântco. 


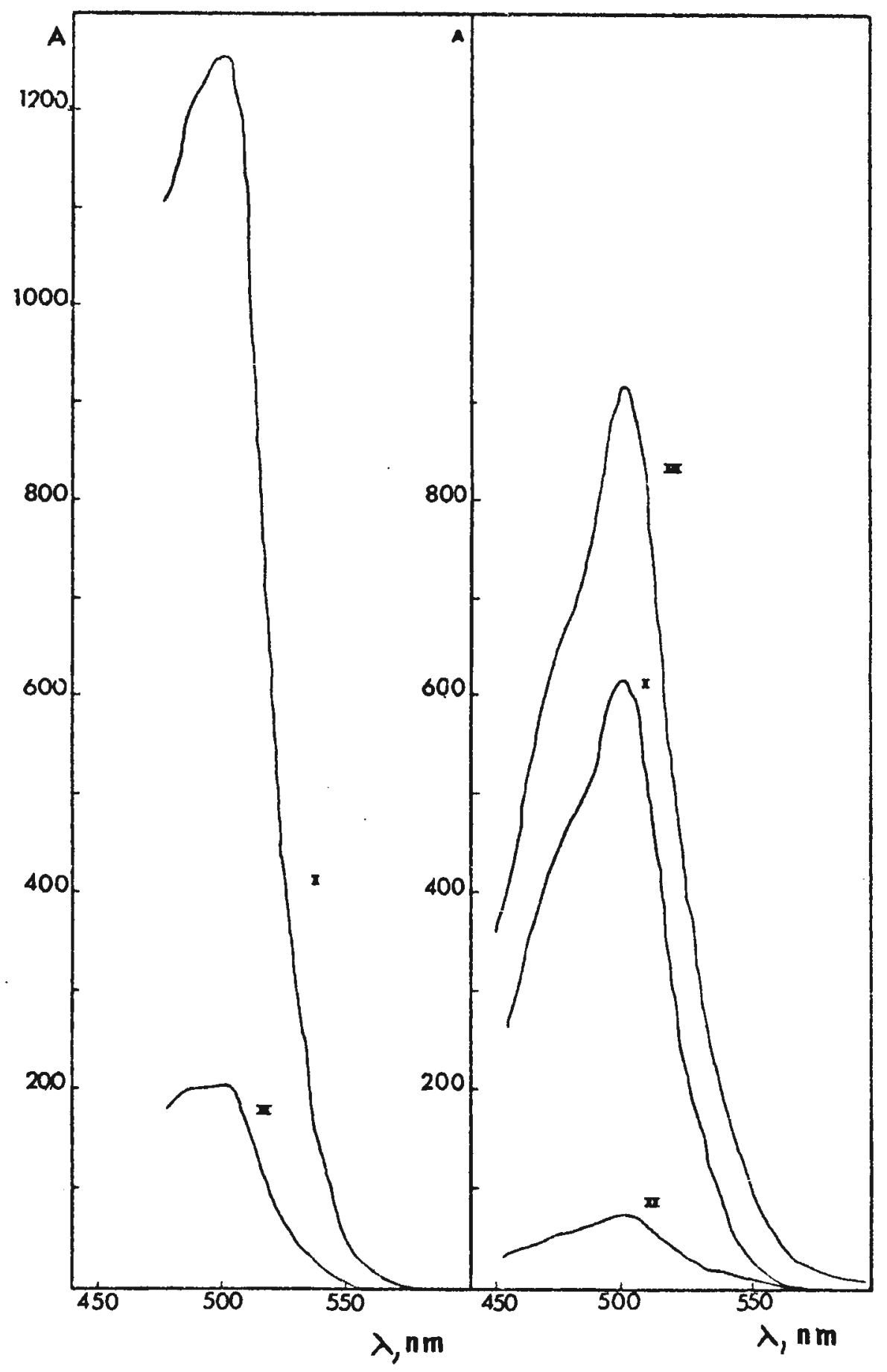

FIGURA 19: Espectro da solução contendo o complexo Mo(VI)fenilfluorona contra o reagente obtida no método analítico para duas concentrações diferentes I e II.

FIGURA 20: Espectros das soluções contendo o composto preparado-Mo (VI) -fenilfluorona contra o solvente para duas concentrações diferentes I e II. Espectro diferencial da solução contendo o composto preparado contra o reagente III. 
4) CARACTERISTICAS FLUORESCENTES DAS SOLUÇŐES DE FENILFLUO RONA E DO COMPOSTO MOLIBDENIO-FENILFLUORONA EM MEIO ORGÃNI CO *

A propriedade de apresentar fluorescência que têm os compostos de estrutura aromática contendo grupos doadores ${ }^{(88)}$ sugeriu que se determinassem os espectros de fluorescência das soluções de fenilfluorona e do comple xo molibdênio-fenilfluorona desenvolvidos no método analítico e, se possível compará-los com o espectro da solução obtida em idênticas condições do composto preparado. Efeti vamente, deve-se esperar alguma caracteristica de fluorescência para estas soluções, uma vez que a fenilfluorona apresenta uma estrutura do tipo das flavonas conhecidas na literatura ${ }^{(89)}$ como reagentes fluorimētrico extremamente sensiveis para certos ions metálicos.

Neste estudo extraiu-se o molibdênio do meio aquoso segundo o procedimento estabelecido anteriormente e adicionou-se o reagente ao extrato orgânico obtido de modo a se ter uma proporção molar de $1: 1$ entre o metal e o 1igante. Obteve-se uma amostra em branco contendo o mesmo teor de reagente. Os espectros de fluorescência destas duas soluções correspondem à figura 21 .

*Agradeço a gentileza de Raul Inacio Cazotti e do Dr. Alcí dio Abrão do IEA que tornaram possível a determinação dos espectros de fluorescência. 


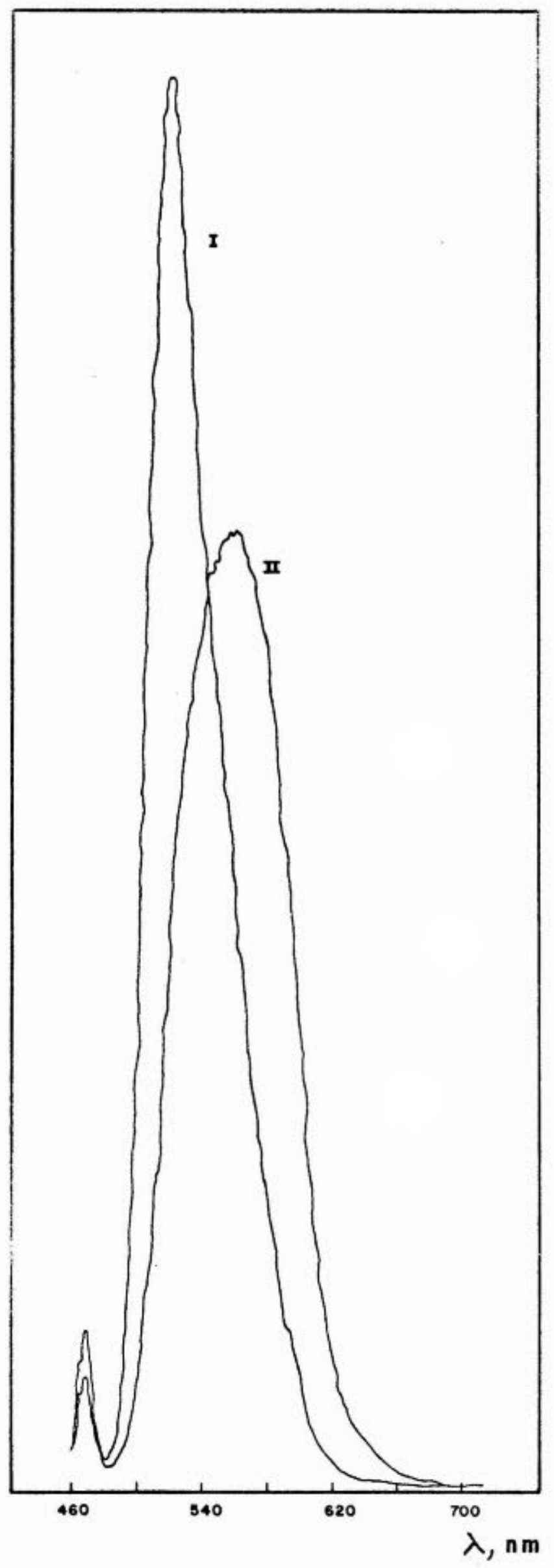

FIGURA 21

I - Espectro de fluorescência da fenilfluorona

II - Espectro de fluorescência do complexo: Mo (VI)-fenilfluorona.

Soluções obtidas do método analítico Proporção metal-ligante $l: l$ 
Paralelamente prepararam-se duas soluções, de fenilfluorona e do complexo obtido, dissolvendo-se cada amostra em $100 \mathrm{ml}$ de uma solução de acetato de n-butila e álcool etílico (segundo o mesmo procedimento indicado na pg 97 ), na proporção idêntica ao do mëtodo analítico. Tan to o complexante quanto o composto foram pesados aproximadamente de modo a se manter a proporção molar de 1:1 entre as duas soluções. Os espectros de fluorescência destas últimas correspondem à figura 22.

Todos esses espectros foram determinados em comprimento de onda de $468 \mathrm{~nm}$ correspondente ao máximo de exitação fluorescente obtido para a solução do complexo.

A intensidade relativa de fluorescência (IRF) das soluções do complexante (I das figuras 21 e 22) apresentou seu máximo em $521 \mathrm{~nm}$ e das soluções contendo o complexo (II das figuras 21 e 22) apresentou seu máximo em $560 \mathrm{~nm}$. Observou-se um pequeno deslocamento dos picos de fluorescência e uma queda na intensidade relativa de fluorescência quando o complexante-fenilfluorona - passou a formar complexo com o molibdênio.

Portanto, concluiu-se que ocorre perfeita coincidência dos máximos entre as soluções obtidas pelo mê todo analítico e as obtidas pela dissolução do complexo preparado. Apenas deve-se ressaltar que a comparação tem objetivos qualitativos de caracterização das soluções uma vez consideradas as dificuldades de se preparar soluções idênticas contendo teores tão mínimos de substância. 


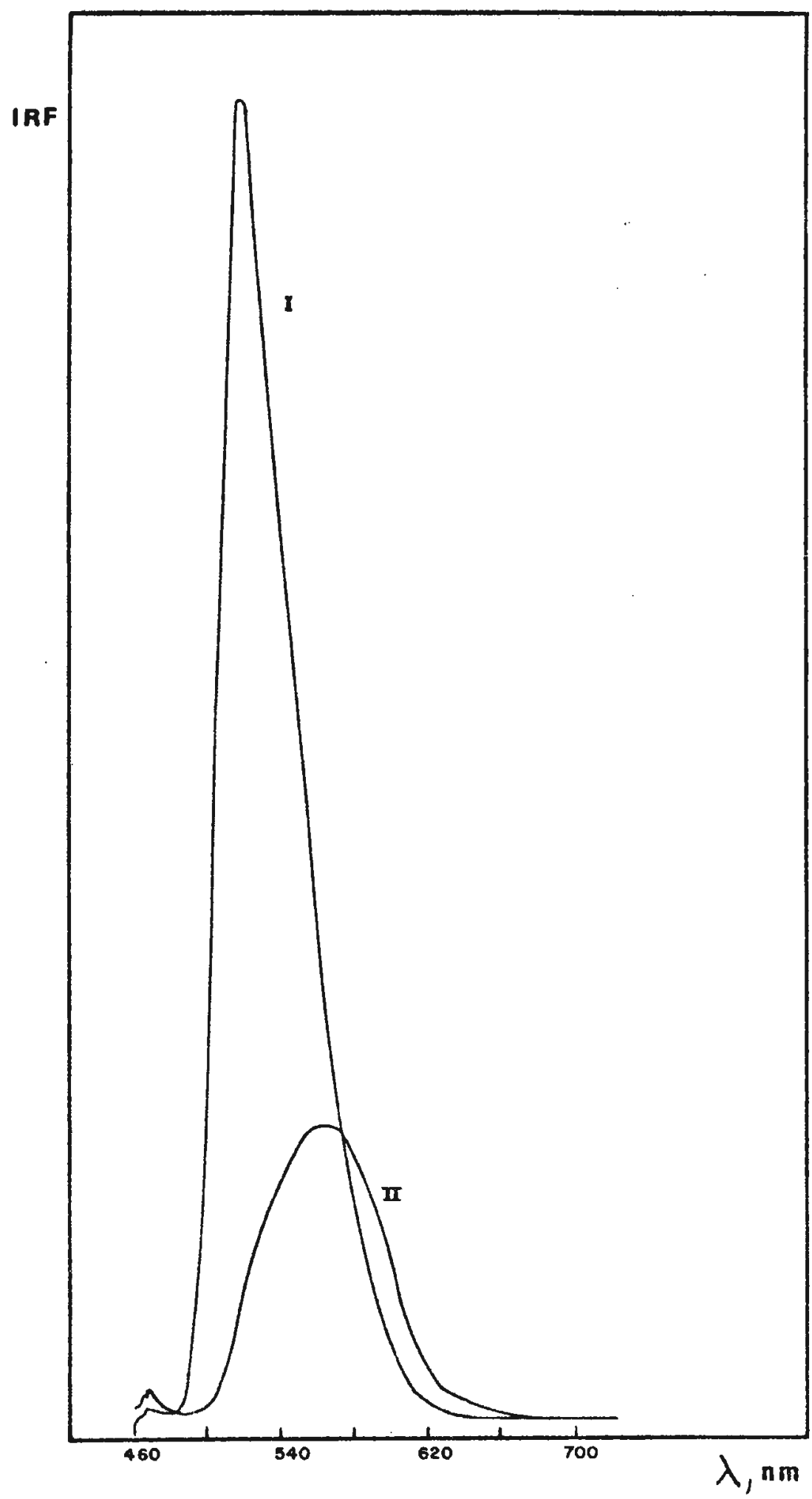

FIGURA 22

I - Espectro de fluorescência da fanilfluorona

II - Espectro de fluorescência do composto preparado

Soluções identicas ao do mëtodo analittico Proporção metal-ligante $1: 1$ 
5) COMPOSIÇÃO DO COMPLEXO MOLIBDENIO-FENILFLUORONA - ESTUDO EM MEIO ORGANICO

Com o objetivo de conhecer a proporção entre o metal e o complexante, fez-se um estudo da composição do complexo pelos métodos das variações Contínuas e da Razão Molar, desenvolvendo a reação em meio orgânico.

Como já constatado anteriormente, a extração do molibdênio segundo as condições estabelecidas pelo mēto do, apresentou elevada eficiência, razão pela qual admitiu-se neste estudo que o elemento foi quantitativamente extraído da solução.

5a) Método das Variações Contínuas ${ }^{(90)}$

Foram feitas extrações de quantidades variāveis de molibdênio, segundo o mëtodo estabelecido, e adicionou-se aos balões volumétricos volumes variāveis do rea gente de forma a obter para a fração molar do molibdênio valores de 0,1 a 1,0. Preparou-se um branco para cada amos tra. Os valores em absorbância obtidos acham-se na tabela 27. 
5b) Método da Razão Molar ${ }^{(91)}$

Neste caso fez-se uma sērie de extraçōes de amostras contendo o mesmo teor de molibdênio e variou-se o teor de reagente adicionado. Preparou-se um branco para ca da amostra. Os resultados acham-se na tabela 28 .

\section{TABELA 27}

Determinação da composição do complexo pelo método das Variações contínuas

\begin{tabular}{|c|c|c|c|}
\hline$\frac{\mathrm{n}_{M o}}{\mathrm{n}_{\mathrm{MO}}{ }^{+\mathrm{n}_{F}}}$ & $\begin{array}{c}\text { Mo na fase } \\
\text { orgânica } \\
\mathrm{M}\end{array}$ & $\begin{array}{c}\text { Reagente } \\
\text { adicionando } \\
\mathrm{V}(\mathrm{ml})\end{array}$ & $\begin{array}{c}\mathrm{A} \\
(506 \mathrm{~nm})\end{array}$ \\
\hline 0,1 & $0,5.10^{-5}$ & 0,72 & 0,233 \\
0,2 & $1,0.10^{-5}$ & 0,64 & 0,477 \\
0,3 & $1,5.10^{-5}$ & 0,56 & 0,703 \\
0,4 & $2,0.10^{-5}$ & 0,48 & 0,860 \\
0,5 & $2,5 \cdot 10^{-5}$ & 0,40 & 0,910 \\
0,6 & $3,0.10^{-5}$ & 0,32 & 0,772 \\
0,7 & $3,5 \cdot 10^{-5}$ & 0,24 & 0,611 \\
0,8 & $4,0.10^{-5}$ & 0,16 & 0,470 \\
0,9 & $4,5.10^{-5}$ & 0,08 & 0,305 \\
\hline
\end{tabular}


Determinação da composição do complexo pelo método da Razão Molar.

\begin{tabular}{|c|c|c|c|}
\hline$\frac{\mathrm{n}_{M O}}{\mathrm{n}_{\mathrm{F}}}$ & $\begin{array}{c}\text { Mo na fase } \\
\text { orgânica } \\
\mathrm{M}\end{array}$ & $\begin{array}{c}\text { Reagente } \\
\text { adicionado } \\
\mathrm{V}(\mathrm{ml})\end{array}$ & $\begin{array}{c}\mathrm{A} \\
(506 \mathrm{~nm})\end{array}$ \\
\hline 4,0 & $2,5.10^{-5}$ & 0,10 & 0,265 \\
2,0 & $2,5.10^{-5}$ & 0,20 & 0,508 \\
1,3 & $2,5.10^{-5}$ & 0,30 & 0,691 \\
1,0 & $2,5.10^{-5}$ & 0,40 & 0,804 \\
0,79 & $2,5.10^{-5}$ & 0,50 & 0,807 \\
0,66 & $2,5.10^{-5}$ & 0,60 & 0,839 \\
0,57 & $2,5.10^{-5}$ & 0,70 & 0,857 \\
0,50 & $2,5.10^{-5}$ & 0,80 & 0,882 \\
\hline
\end{tabular}

Observando-se as figuras 23 e 24 obtidas pelos dois métodos conclui-se que efetivamente a reação entre o moltbdênio e a fentlfiluorona ocorre na proporção de $1: 1$. 


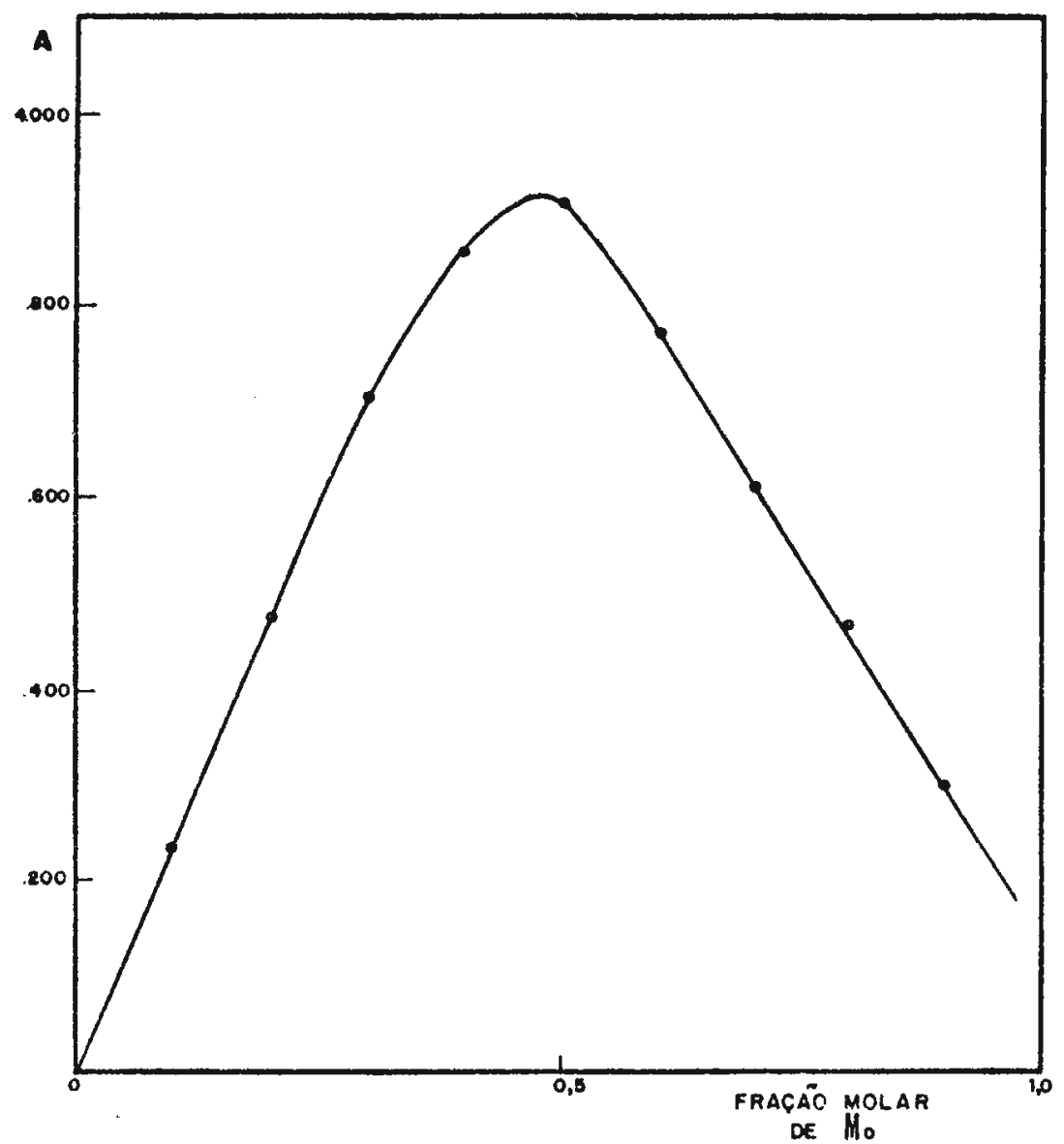

FIGURA 23

Mētodo das variações contínuas

$$
\mathrm{C}_{\mathrm{Mo}}+\mathrm{C}_{\mathrm{Ff}}=5,0 \cdot 10^{-5} \mathrm{M}
$$

Reação em meio orgânico 


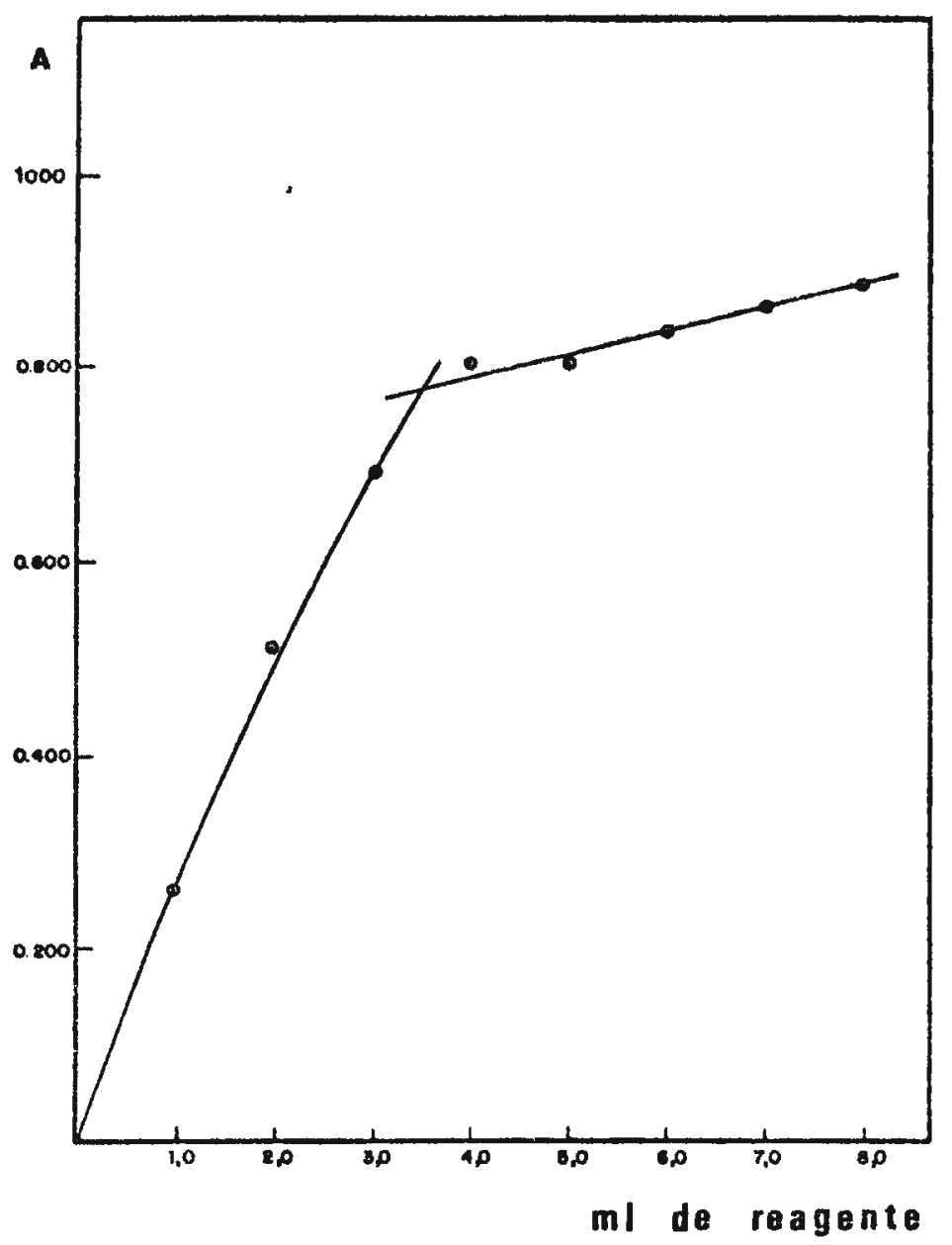

FIGURA 24

Método da razão molar

$$
C_{\text {MO }}=2,5 \cdot 10^{-5} \mathrm{M}
$$

Reação em meio orgânico 


\section{6) ALGUMAS CARACTERISTICAS DO COMPOSTO MOLIBDENIO-FENILFLUORONA NO ESTADO SOLLIDO}

Reuniram-se aquí alguns dados obtidos do estudo feito com o composto molibdênio-fenilfluorona sólịdo.

\section{6a) Espectro de Reflectância}

Determinou-se o espectro de reflectância entre 450 e $600 \mathrm{~nm}$ utilizando como referência o óxido de mag nësio que não absorve nesta região(92).

A amostra constituiu-se num papel de filtro Wathmann número 1 impregnado da solução contendo o complexo, depois de sêco, por evaporação ao ar dos solventes. Ob serva-se na figura 25 que o composto apresentou dois máximos de reflectāncia correspondente a $464 \mathrm{~nm}$ e $562 \mathrm{~nm}$. 


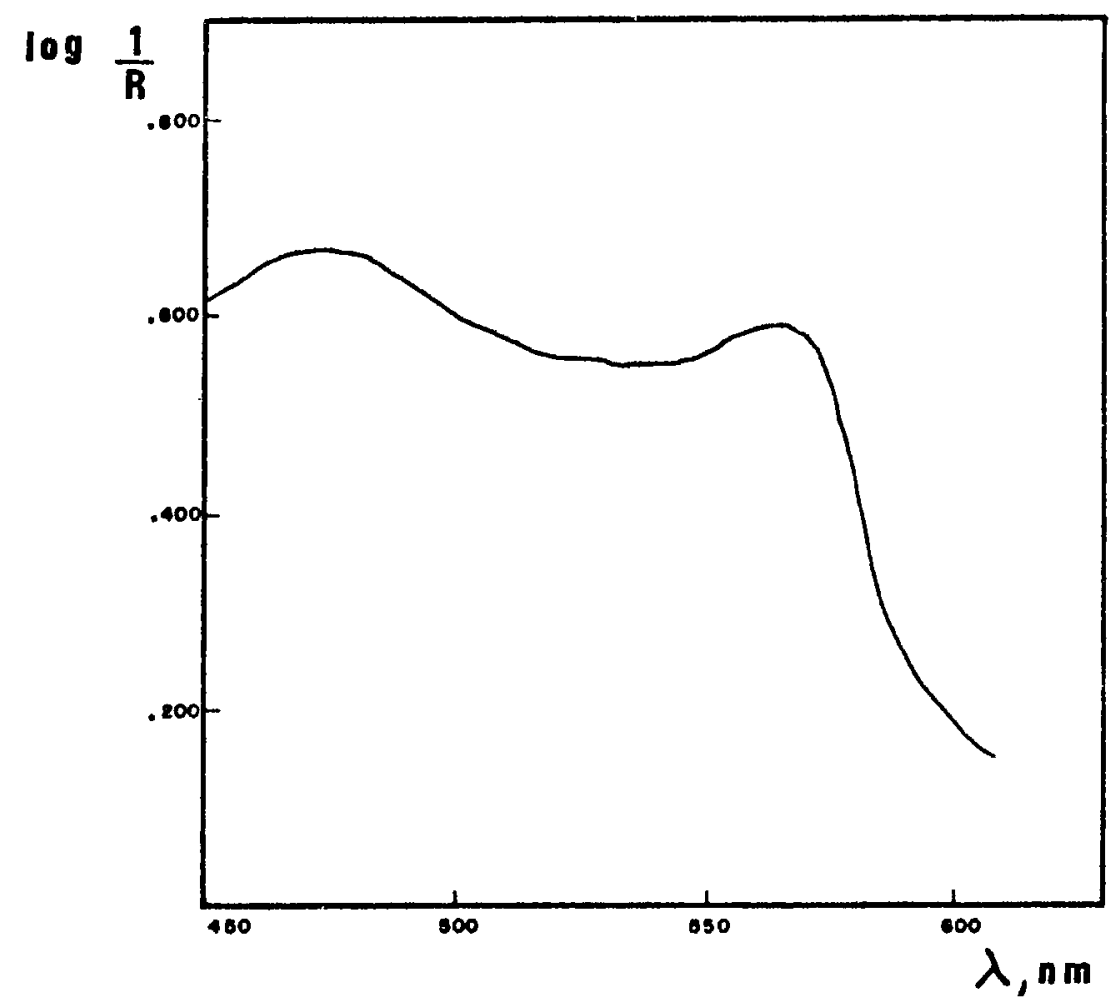

FIGURA 25

Espectro de reflectância do composto Mo (VI)-fenilfluorona

papel Wathaman-l

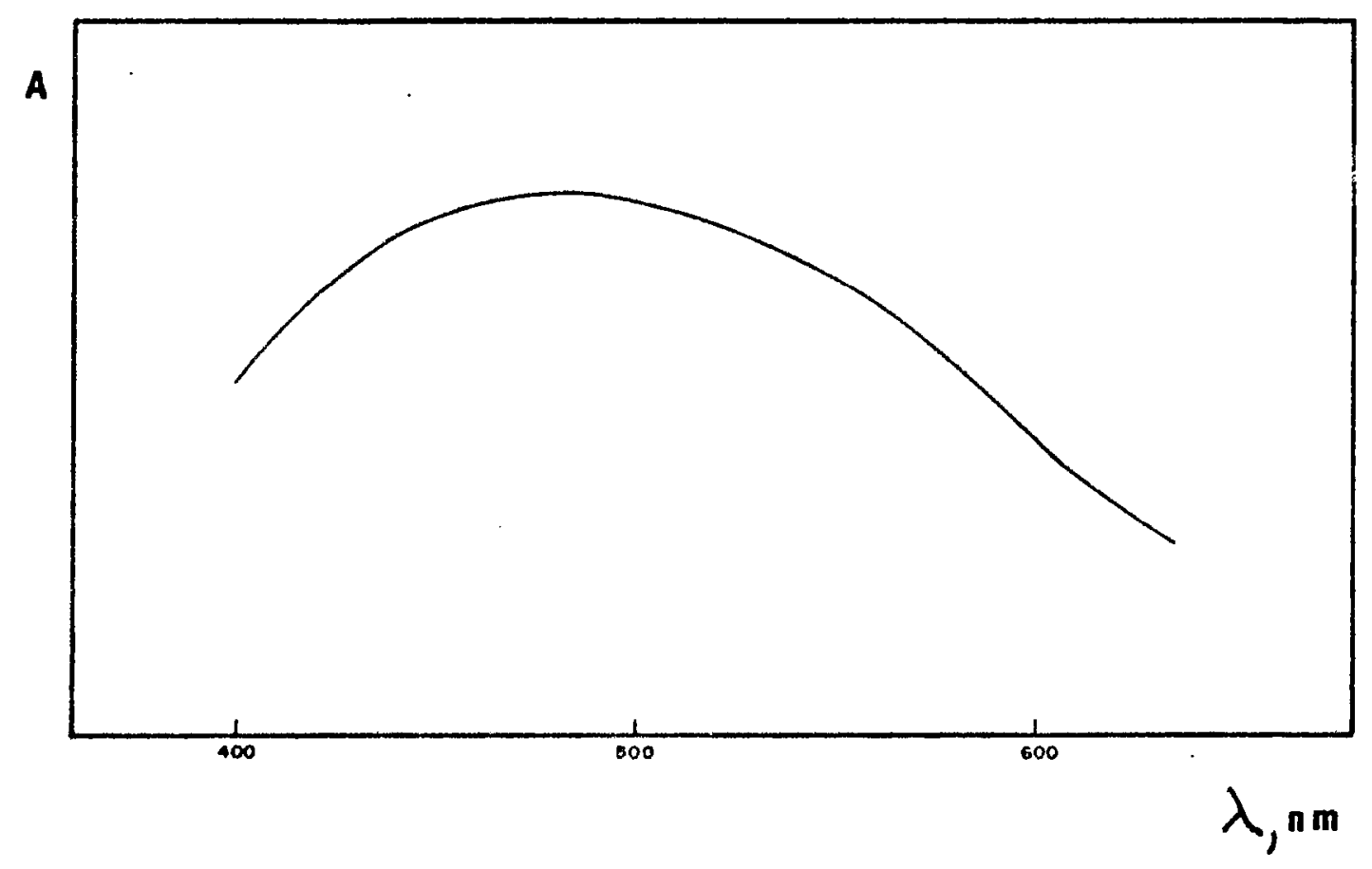

FIGURA 26

Espectro eletrônico no visível do composto Mo (VI) - fenilfluorona

Emulsão em Nujol papel Wathman-l impregnado 
6b) Espectro eletrōnico no Visível

Determinou-se o espectro eletrônico do sólido em emulsão de Nujol ut1lizando a técnica descrita por cotton (93).

Observa-se nà figura 26 que o composto apresentou uma região de máximo entre 470 e $490 \mathrm{~nm}$ e um suave aumento na curva de absorção para a região de 560 a $580 \mathrm{~nm}$.

Estes dois espectros, que se assemelham entre si, mostram que o composto sólido tem estrutura diferente do que em solução uma vez que as regiões de māxima absorção não coincidem. o composto em solução apresenta o mäximo entre 480 e $510 \mathrm{~nm}$, dependendo do solvente e da aci. dez da solução e o composto sólido apresenta duas regiões de máximo respectivamente de 470 a $490 \mathrm{~nm}$ e 560 a $530 \mathrm{~nm}$.

7) TEOR DE MOLIBDENIO NO COMPOSTO

Com as soluções obtidas apōs a destruição do complexo (ver cap. IX - pg 135) foram feitas determinações do teor de molibdênio presente segundo procedimento estabe lecido pelo mētodo analítico descrito à pg 57 . Os resultados destas determinações estão na tabela 29. 
TABELA 29

Determinação do teor de Mo(VI) no composto

\begin{tabular}{|c|c|c|}
\hline $\begin{array}{c}\text { compos to pesado } \\
\mathrm{g}\end{array}$ & $\begin{array}{c}\text { Mo encontrado } \\
\mathrm{g}\end{array}$ & 8 \\
\hline 0,01947 & 0,003080 & 15,8 \\
0,01727 & 0,002840 & 16,5 \\
0,02935 & 0,004561 & 15,5 \\
\hline
\end{tabular}

Nazarenko e colaboradores ${ }^{(96)}$, ao estudarem a composição dos complexos de germânio, zircônico, antimônio e escândio com a fenilfluorona e a propil fluorona, concluiram que esses complexantes se ligavam ao metal pelos grupos o-hidroxiquinona e näo com os grupos o-difenois. Por outro lado, Shustova e Nazarenko ${ }^{(55)}$ ao estudaram as reações, em meio ăcido, de 13 derivados da trihidroxifluorona com o molibdênio verificaram que o mesmo desloca apenas um hidrogênio do mol do reagente.

Efetivamente, o teor de molibdênio encontrado no composto preparado não corresponde ao valor calculado ao se supor uma ligação atravēs dos grupos o-difenōlicos - o que conduziría a um quelato neutro. Portanto, os resultados aquí obtidos parecem confirmar as observaçöes dos autores citados. Entretanto, è de todo conveniente res saltar que um estudo mais aprofundado sería necessārio para se chegar à conclusões definitivas principalmente levan do em conta a conhecida capacidade do molibdênio de formar polímeros. 
VI - APLICAÇÃO DO METODO

Anālise de uma liga de "Vitallium"

A fim de testar a eficiência do método elabo rado neste trabalho, procedeu-se à anālise de uma liga de "Vitallium". Trata-se de uma liga de cobalto em cuja compo sição entram os seguintes elementos em teores mais baixos: $\mathrm{Cr}, \mathrm{Fe}, \mathrm{Mn}, \mathrm{C}, \mathrm{Si}$ e Mo. O material foi analisado pelo Instituto de Pesquisas Tecnológicas que indicou o teor de 5,508 para $\circ$ molibdênio.

A liga (pesada exatamente) foi tratada com ācido cloríarico $1: 1$. Após vărias horas de aquecimento brando chegou-se à dissolução quase completa. Em seguida adicionou-se $1 \mathrm{ml}$ de ácido nítrico e $1 \mathrm{ml}$ de ācido sulfúrí co concentrado. Manteve-se o aquecimento até completa dissolução do material e desenvolvimento de fumos brancos. Es friou-se, diluiu-se ao dobro e aqueceu-se levemente para aissolver os sais formados. Levou-se o volume a $250 \mathrm{ml}$ em salão volumētrico com àgua destilada.

Desta solução pipetou-se uma alíquota de $0,50 \mathrm{ml}$ para um tubo de extração, adicionou-se $0,05 \mathrm{ml}$ ( 1 jota) de ácido ascórbico $10 \%$ e procedeu-se à determinação to molibdênio de acordo com o método elaborado.

\begin{tabular}{|l|l|}
\hline 8Mo (I.P.T.) & 8Mo (segundo método com fenilfluorona) \\
\hline 5,50 & 5,$18 ; 5,20 ; 5,35$. \\
\hline
\end{tabular}




\section{VII - ESTUDO POLAROGRAFICO}

\section{1) CONSIDERAÇÕES GERAIS}

A importância da separação molibdênio-tungstênio, ou da determinação analítica de um na presença do outro, sugeriram alguns ensaios com o objetivo de encontrar eventuais novos caminhos, sem deixar de aproveitar as vantagens da extração nos moldes em que foi descrita e que, como foi mostrado, permite evitar a influência de grande nümero de ions extranhos.

Neste sentido, pensou-se em utilizar a técni ca polarográfica em lugar 'da espectrofotométrica, tendo em mente a possibilidade de tirar partido da conhecida onda catalítica que se pode obter com soluções de molibdato que contenham nitrato.

Em 1937, Uhl ${ }^{(97)}$ assinalou as primeiras observações referentes à onda polarogrāfica catalítica que o Mo(VI) desenvolve em meio ácido na presença de nitrato. Se gundo o autor, obtem-se uma única onda polarográfica, bem formada, quando se tem $\mathrm{MO}$ (VI) em solução $3 \mathrm{M} \mathrm{em} \mathrm{NH}_{4} \mathrm{NO}_{3}$ e $0,25 \mathrm{M} \mathrm{em} \mathrm{HNO}_{3}$ como eletrólito de suporte; é essencial para - desenvolvimento da onda uma alta concentração de nitrato e relativamente baixa concentração de ácido nītrico. 
Em 1942, Adolph Stern ${ }^{(98)}$ utilizou para fins analíticos as observações de Uhl, numa determinação indire ta de fosfato.

Posteriormente, vārios autores estudaram o comportamento polarogrāfico do Mo(VI) em soluções ãcidas contendo, além do nitrato, o clorato e o perclorato $(99,100)$ e verificaram também o efeito catalítico com estes eletrólitos. Tais trabalhos se referem fundamentalmente ao complexo problema dos mecanismos da catálise; apenas algumas aplicações analíticas de determinação do Mo(VI) foram desenvolvidas utilizando curvas de calibração(101,102) - corrente em função da concentração do elemento.

Em conformidade com os nossos objetivos, pro curou-se verificar a influência do tungstênio no fenōmeno, ou seja, o efeito da presença de W(VI) na onda catalítica que se obtem com Mo(VI), utilizando como eletrōlito de suporte uma solução $3 \mathrm{M}$ em $\mathrm{NaNO}_{3}$ e $0,3 \mathrm{M}$ em $\mathrm{HNO}_{3}$.

Os dados colhidos poderão mostrar a possibilidade de eventual aproveitamento analitico. 
2) INFLUENCIA DO W(VI) NA ONDA CATALITICA DO MO(VI).

A presença de W(VI) afetou a altura da onda catalítica do Mo(VI) no sentido de diminuíla com o aumento da concentração de W(VI), à semelhança do que fora ante riormente observado, embora em condiçōes diferentes (104). Este efeito, que pode ser notado na figura 27 , mostra que - decréscimo na altura da onda não é proporcional à concen tração crescente de $W(V I)$, sendo maior para concentrações menores e diminuindo à medida que a concentração aumenta. Figura 28.

A adição de citrato, com o objetivo de inibir o efeito do W(VI), à semelhança do que ocorreu no méto do colorimétrico, afetou a própria onda catalítica do Mo(VI), fazendo-a decrescer acentuadamente.

Estas observações conduziram à idéia básica de se utilizar uma curva de calibração \{corrente em função da concentração do Mo(VI) \}, mantendo-se fixo um certo teor de W(VI) em todas as amostras ou seja, empregar uma onda polarográfica catalítica do Mo(VI) já afetada pela presença de certo teor de $W(V I)$. Isto possibilitaría estabelecer um método de determinação do Mo(VI), baseado no fato de que a extração do elemento do meio aquoso arrasta consigo certo teor de W(VI) que sería desprezível com relação ao adicionado intencionalmente às amostras para a determinação polarogrāicica. 


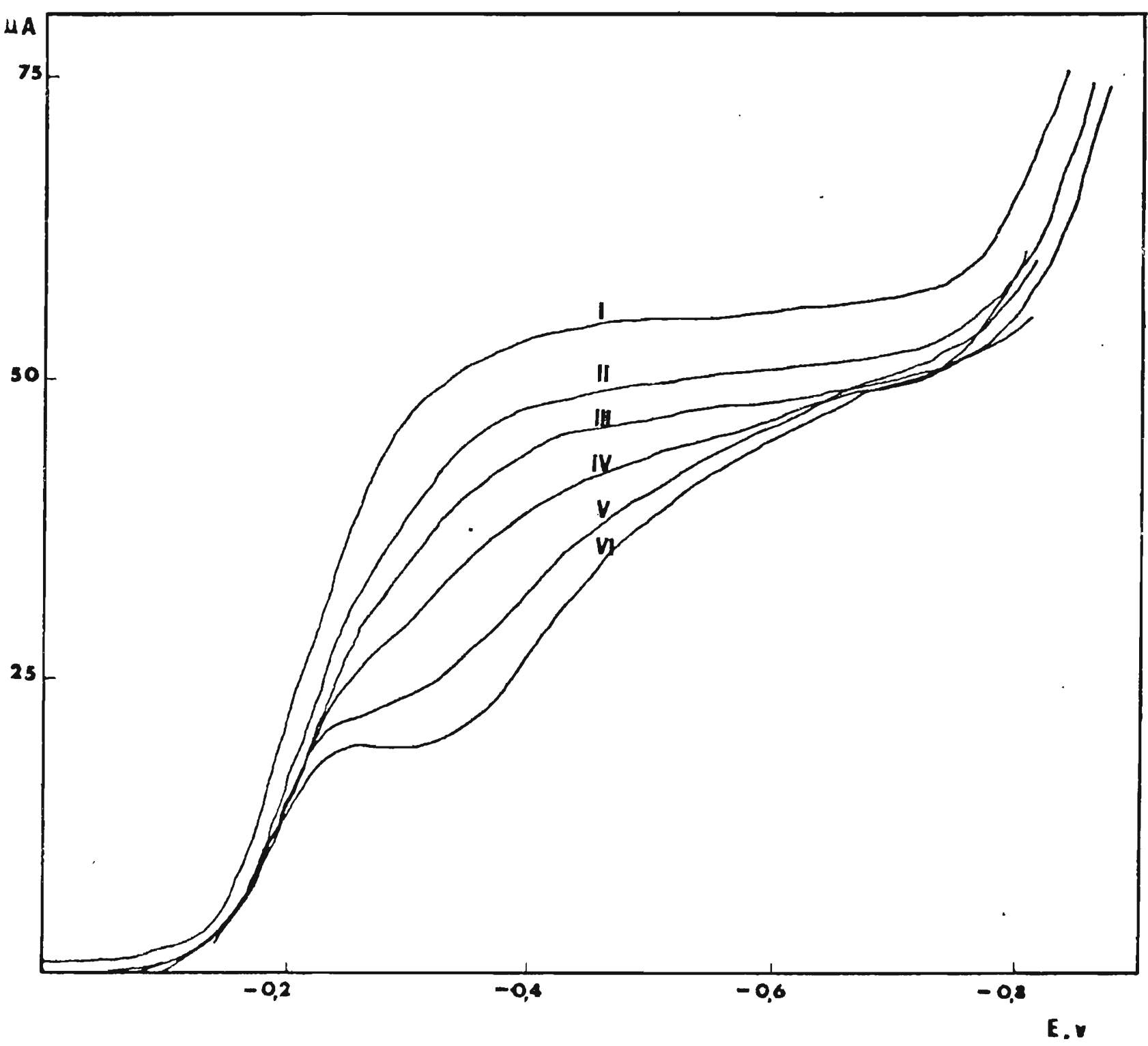

FIGURA 27

Efeito do $W(V I)$ na onda catalítica do Mo(VI)

I - solução $1,0.10^{-4} \mathrm{M} \mathrm{Mo}(\mathrm{VI})$

II - solução $1,0 \cdot 10^{-4} \mathrm{M} \mathrm{Mo}(\mathrm{VI})$ e $0,5 \cdot 10^{-4} \mathrm{MW}$ (VI)

III - solução $1,0.10^{-4} \mathrm{M} M O(V I)$ e $1,0.10^{-4} \mathrm{M} W(V I)$

IV - solução $1,0 \cdot 10^{-4} \mathrm{M} M O(V I)$ e $2,0.10^{-4} \mathrm{M} W(V I)$

$V$ - solução $1,0 \cdot 10^{-4} \mathrm{M} \mathrm{Mo}(\mathrm{VI})$ e $3,0.10^{-4} \mathrm{M} \mathrm{W}(\mathrm{VI})$

VI - solução $1,0.10^{-4} \mathrm{M}$ MO(VI) e $4,0.10^{-4} \mathrm{M} W(V I)$

$$
\begin{aligned}
\text { E.S. }= & 3,0 \mathrm{M} \mathrm{KNO}_{3} \text { e } 0,3 \mathrm{M} \mathrm{HNO}_{3} \\
& \text { E(v) } \mathrm{x} \text { E.C.S. }
\end{aligned}
$$




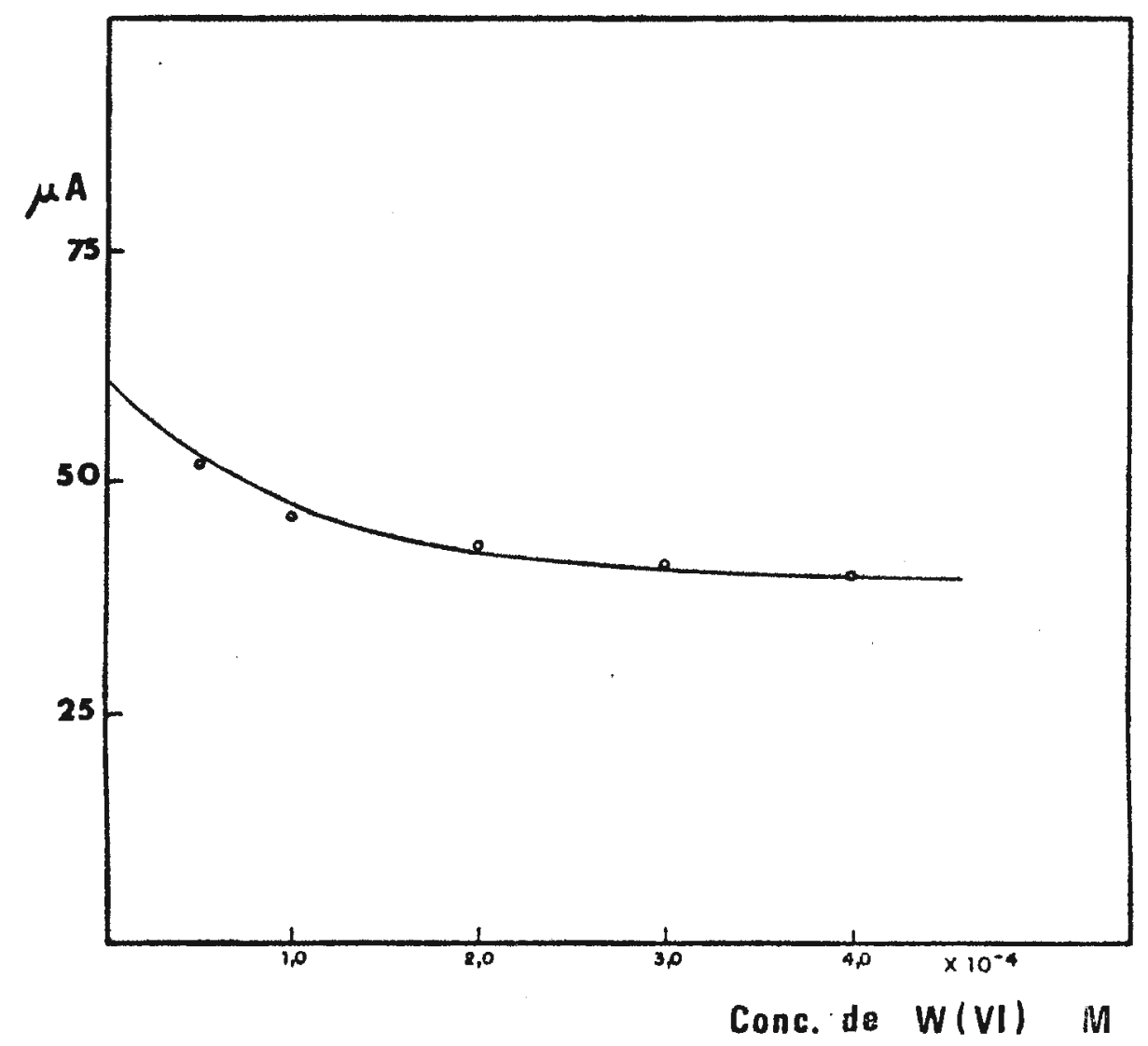

FIGURA 28

Efeito da concentração de W(VI) na onda catalítica do Mo(VI)

$C_{\text {MO }}=1,0 \cdot 10^{-4} \mathrm{M}$

E.S. - 3,0M $\mathrm{KNO}_{3}$ e $0,3 \mathrm{M} \mathrm{HNO}$

$E=-0,600 \mathrm{v} \times$ E.C.S. 
3) CURVAS DE CALIBRAÇÃO: CORRENTEE EM FUNÇÃO DA CONCENTRAÇÃO DE MO(VI) E EM FUNÇÃO DA CONCENTRAÇÃO DO MO(VI) COM TEOR FIXO DE W(VI).

o estudo feito neste sentido permitiu traçar duas curvas de calibração que diferem entre si no teor de $W(V I)$. As figuras 29 e 30 mostram a variação da corrente para $O$ intervalo de concentração de $0,1 \cdot 10^{-4}$ a $2,0 \cdot 10^{-4} \mathrm{M}$ de Mo(VI) e duas concentrações fixas de $W(V I)$, respectivamente $2,5 \cdot 10^{-4} \mathrm{M}$ e $5,0 \cdot 10^{-4} \mathrm{M}$. As curvas de calibração que se obteve, figura 31, foram determinadas nos potenciais de $-0,760$ volts (II) e $-0,380$ volts (III) contra o E.S.C., res pectivamente.

Fez-se algumas determinações do Mo(VI) na presença de teores variáveis de $W(V I)$, utilizando-se as curvas de calibração. Os resultados mostraram a viabilidade do método. Tabela 30. 


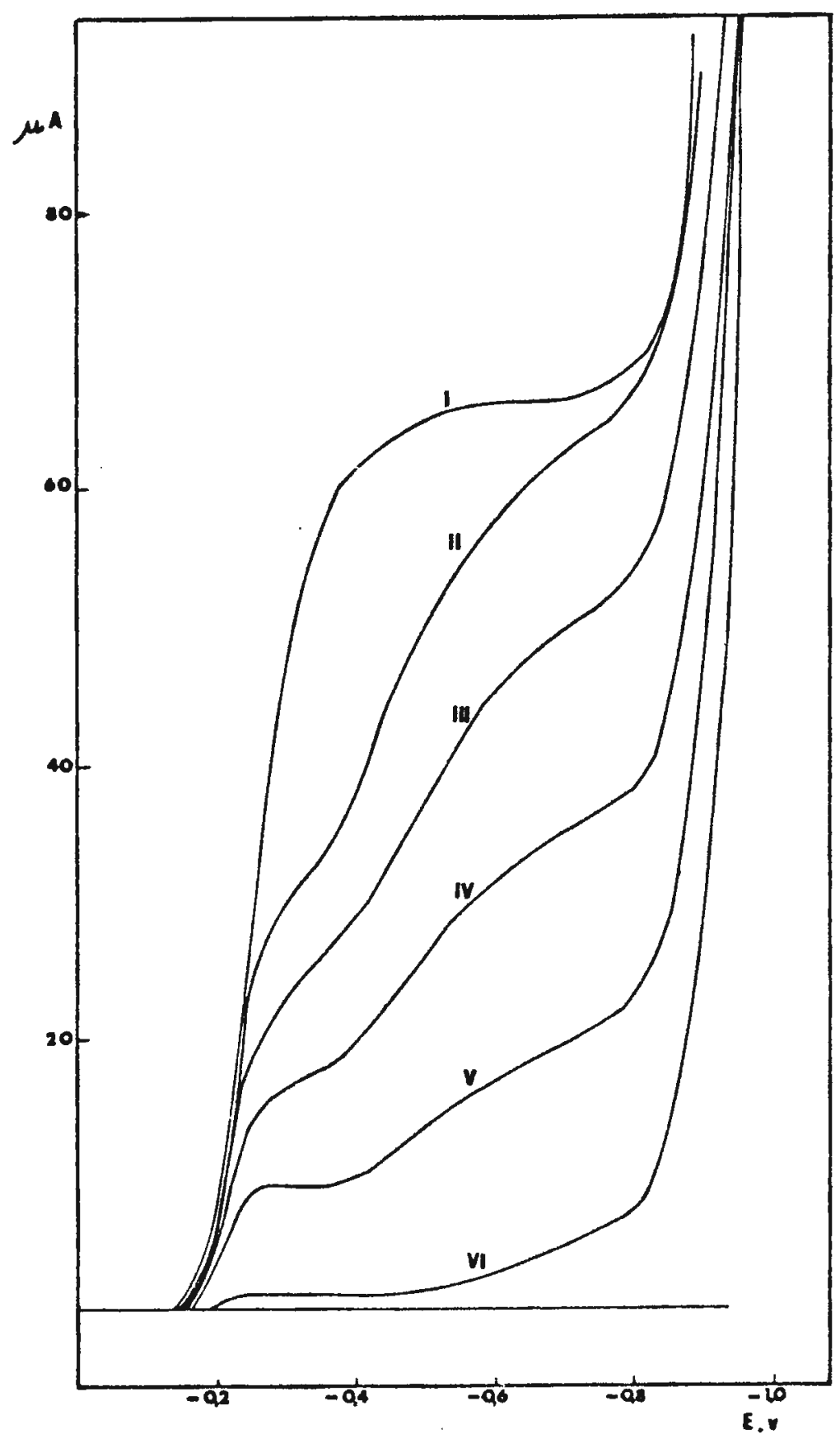

FIGURA 29

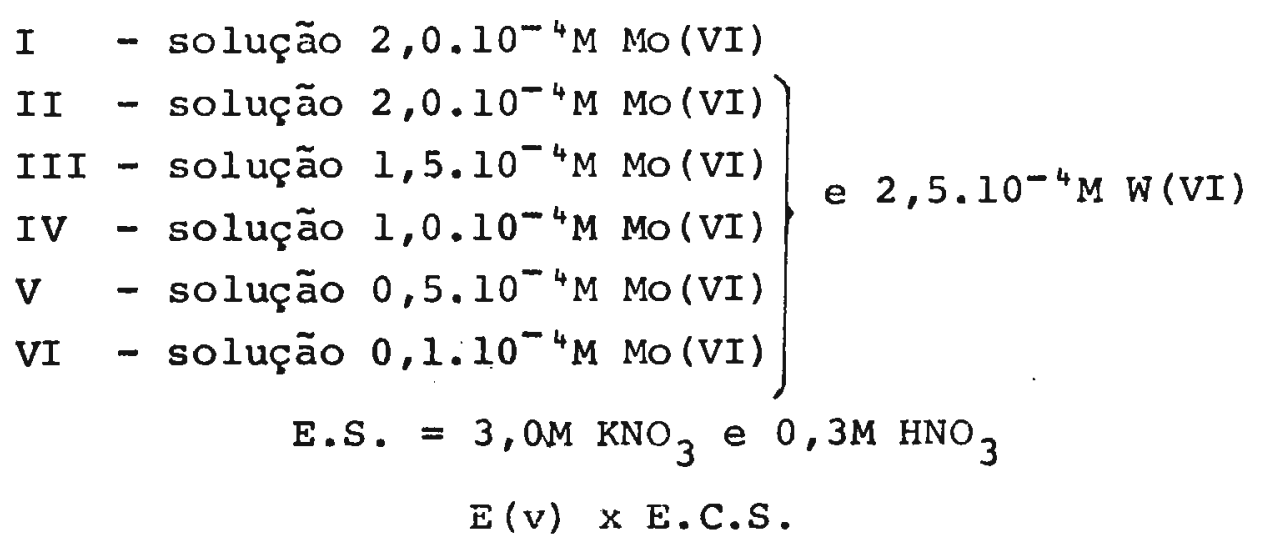




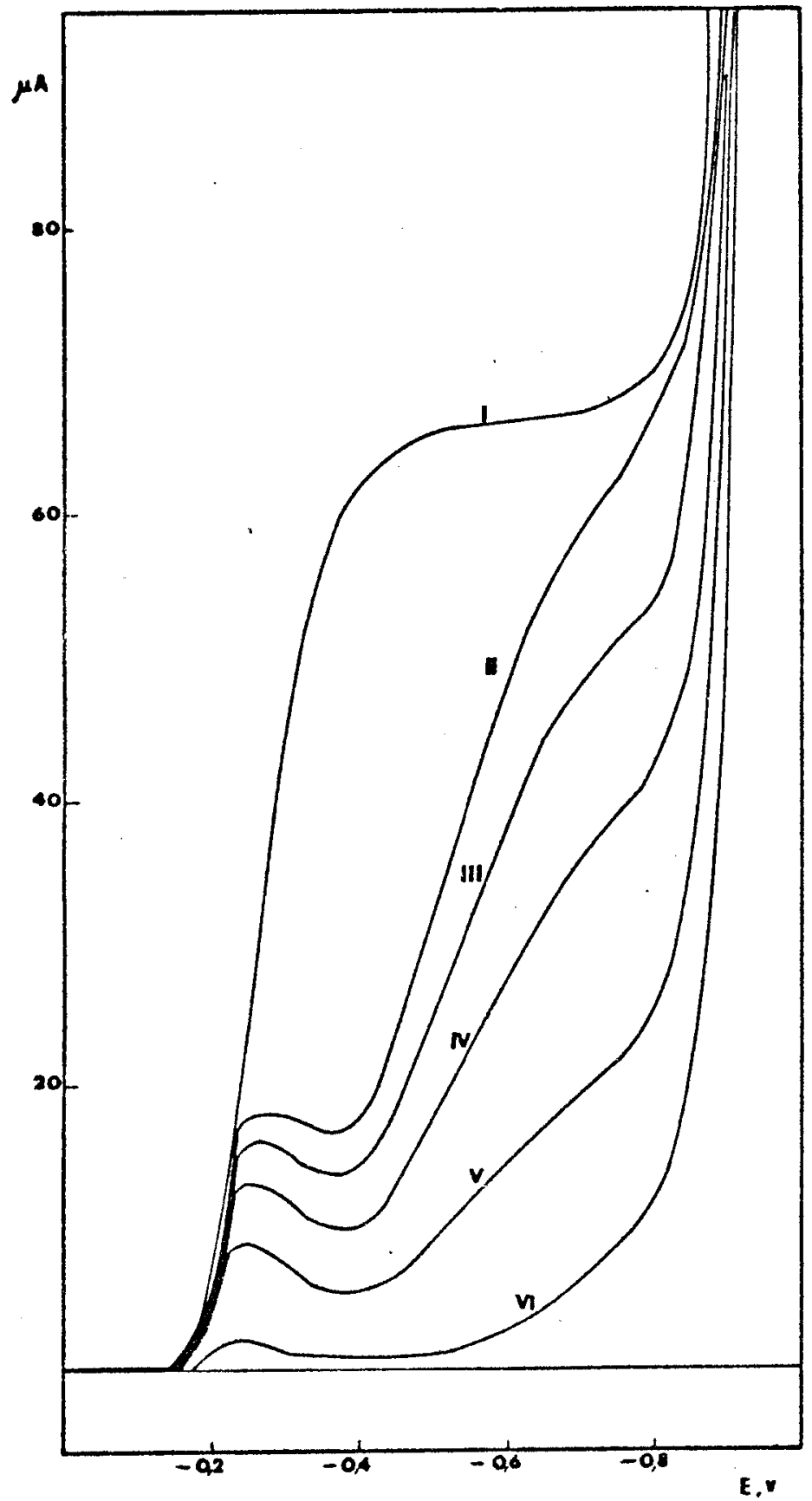

FIGURA 30

$$
\begin{aligned}
& \text { I } \quad \text { solução } 2,0 \cdot 10^{-4} \mathrm{M} \text { Mo(VI) } \\
& \text { II - solução } 2,0.10^{-4} \mathrm{M} \text { Mo(VI) } \\
& \text { III - solução } 1,5 \cdot 10^{-4} \mathrm{M} \mathrm{Mo}(\mathrm{VI}) \\
& \text { IV - solução } 1,0.10^{-4} \mathrm{M} \text { Mo(VI) } \\
& V \text { - solução } 0,5 \cdot 10^{-4} \mathrm{M} \mathrm{Mo}(\mathrm{VI}) \\
& \text { VI - solução } 0,1 \cdot 10^{-4} \mathrm{M} \text { Mo(VI) } \\
& \text { E.S. }=3 \mathrm{M} \mathrm{KNO}_{3} \text { e } 0,3 \mathrm{M} \mathrm{HNO} \\
& \text { E(v) X E.C.S. }
\end{aligned}
$$




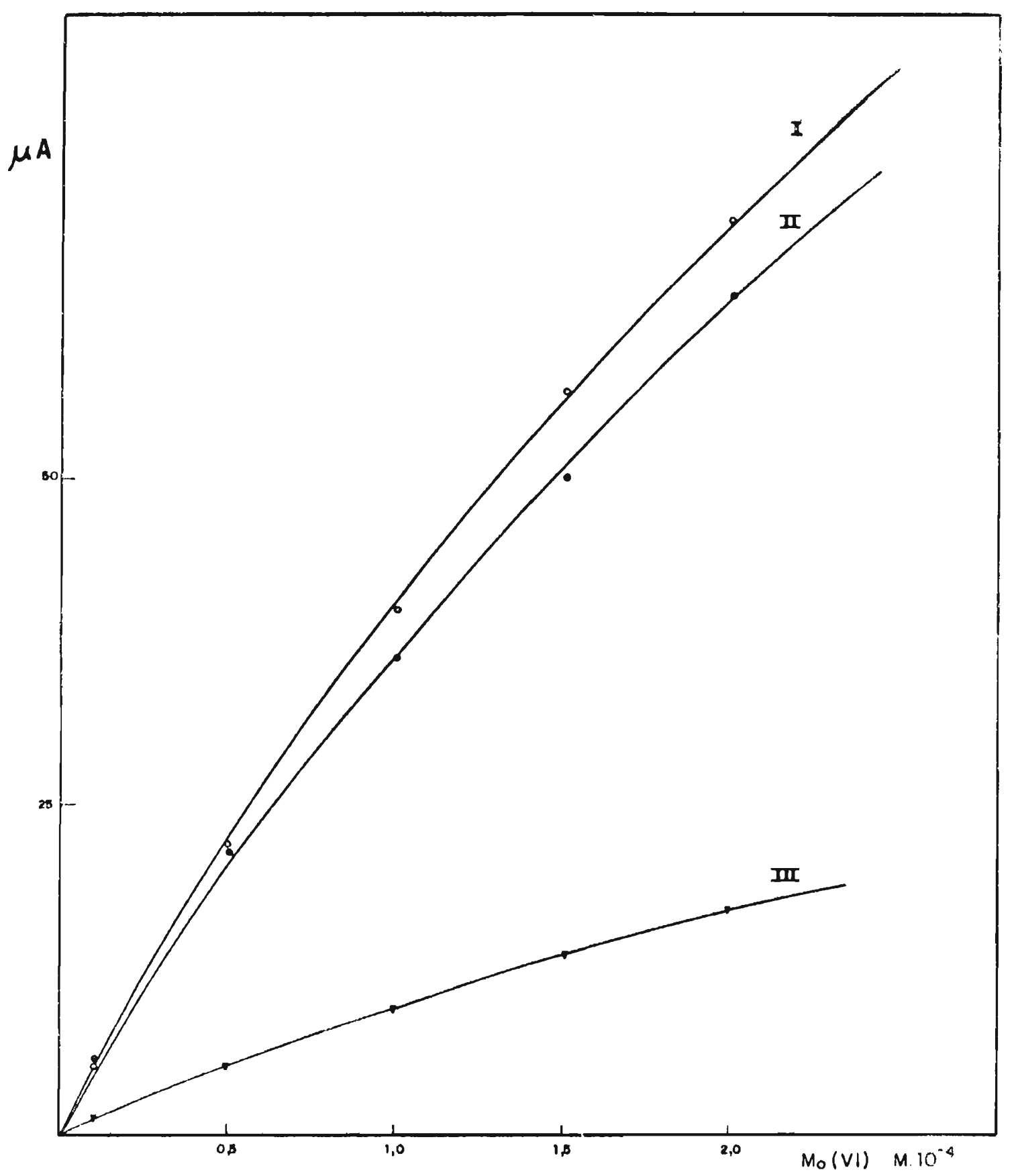

FIGURA 31

I - Curva de calibração apenas para Mo(VI)

II - Curva de calibração Mo(VI) + $2,5 \cdot 10^{-4} \mathrm{M} \mathrm{W}(V I)$

III - Curva de calibração $M o(V I)+5,0.10^{-4} \mathrm{MW}(V I)$

I e II $E=-0,760 \mathrm{v} \times$ E.C.S.

III $E=-0,380 \mathrm{v} \times$ E.C.S.

E.S. $=3 \mathrm{M} \mathrm{KNO}_{3} \in 0,3 \mathrm{M} \mathrm{HNO}_{3}$ 
TABELA 30

Determinação de Mo(VI) na presença de baixos teores de W(VI)

\begin{tabular}{|c|c|c|c|c|c|c|}
\hline & $\begin{array}{l}\mathrm{C}_{\mathrm{MO}} \\
10^{-4} \mathrm{M}\end{array}$ & $\begin{array}{c}C_{W} \\
\times 10^{-4} \mathrm{M}\end{array}$ & $\begin{array}{l}C_{W(\text { final })} \\
\times 10^{-4} \mathrm{M}\end{array}$ & $\mu \mathrm{A}$ & $\begin{array}{c}8 \text { erro } \\
\text { na deter } \\
\text { minação }\end{array}$ & $\begin{array}{l}\text { Potencial } \\
\text { aplicado } \\
\text { xE.C.S.,V }\end{array}$ \\
\hline & 0,5 & $\longrightarrow$ & 5,0 & 4,4 & 0,0 & \\
\hline & 0,5 & 0,5 & 5,5 & 4,6 & $+4,5$ & $-0,380$ \\
\hline & 0,5 & 1,0 & 6,0 & 4,2 & $-4,5$ & \\
\hline & 0,5 & - & 2,5 & 19,4 & $-3,0$ & \\
\hline & 0,5 & 0,25 & 2,75 & 19,4 & $-3,0$ & $-0,760$ \\
\hline & 0,5 & 1,0 & 3,5 & 20,0 & 0,0 & \\
\hline
\end{tabular}

Como já foi visto nos capítulos anteriores , quando se extrai o Mo(VI) do meio aquoso, segundo as condi ções estabelecidas no mētodo colorimētrico, o W(VI) é coex traído e prejudica as determinações. Efetivamente, pôde-se constatar no decorrer de todo o trabalho que o W(VI) é extraído em pequena quantidade ficando a maior parte no meio aquoso. Aliás, a extração quantitativa do mesmo ocorre sòmente a partir de soluções $7,5 \mathrm{~N}$ em HCl. Verificou-se também que a reversão à fase aquosa era perfeitamente exequível segundo aquelas condições de trabalho (pg 49).

Neste sentido, seria bastante viāvel estabelecer um método de determinação do Mo(VI) baseado na sua extração do meio aquoso, reversão e subsequente determinação por via polarográfica. A extração do elemento, sendo seletiva para grande número de íons que forçosamente inter 
ferem numa determinação polarográfica direta, aumentaría sensivelmente o interesse analitico do método. E, por outro lado, a interferência devida ao W(VI) sería praticamen te eliminada pela utilização de uma onda catalítica adequa da contendo um teor fixo de $W(V I)$, como se pode concluir do estudo feito.

Deve-se ainda ressaltar que o trabalho descrito neste capitulo se refere a uma faixa de concentração de Mo(VI) dez vezes superior àquela em que foram feitas as extrações no método colorimétrico. Entretanto, nada impedi ría que se empregassem volumes dez vezes menores de amostra final e se substituísse a cela polarográfica de $10 \mathrm{ml}$ por outra de $1 \mathrm{ml}$. Ou, ainda se mantivesse aquela faixa de concentração extraindo o Mo(VI) em teor dez vezes superior. Alguns estudos feitos neste sentido mostraram a viabilidade nos dois casos.

Os resultados obtidos mostram que o assunto merece ser desenvolvido de maneira mais ampla, pois eviden ciam claramente a possibilidade de se chegar, com técnica simples, a método muito sensível. 


\section{VIII - CONSIDERAÇס̃ES FINAIS}

o estudo sistemātico da extração do molibdênio(VI) no sistema clorídrico permitiu que se encontrassem condições de extração quantitativa do elemento, partindo de soluções $6 \mathrm{~N}$ em ácido clorídrico e utilizando como solvente $o$ acetato de n-butila.

O desenvolvimento da reação entre o molibdènio e a fenilfluorona no próprio extrato orgânico foi instantâneo e as soluções obtidas mostraram-se estáveis por mais de 24 horas, sem exigir cuidados especiais. Assim, foi possivel elaborar um método colorimétrico de determina ção do elemento baseado na sua reação com fenilfluorona, no próprio extrato orgânico, mediante $\circ$ ajuste adequado das condições experimentais. A faixa de concentração favorável para as determinações foi de 0,45 a $1,8 \mu \mathrm{g}$ de $\mathrm{Mo} / \mathrm{ml}$ o que mostra a extraordinária sensibilidade do método e , dentro das condições de trabalho, obteve-se excelente precisão nas determinações.

Como jā se assinalou na introdução desta tese, a maior parte dos métodos de determinação do molibdênio basei-se na sua separação prévia da solução original mediante estração com $\alpha$-benzoinoxima, reversão à fase aquosa e posterior determinação colorimétrica com diferentes reagente. Este processo se faz necessārio inclusive na 
queles métodos em que o molibdênio é novamente extraído do meio aquoso com solventes e depois determinado.

Neste sentido, cabe assinalar que o método aquí apresentado tornou desnecessāria a extração do molibdênio com $\alpha$-benzoinoxima devido, em primeiro lugar, à sele tividade do reagente e em segundo lugar à extração direta do meio aquoso, permitindo que vários íons que normalmente reagem com a fenilfluorona ficassem retidos na solução. As sim, praticamente apenas $\circ W(V I)$ constituiu-se em interferência grave exigindo um estudo mais aprofundado. E, como consequencia do mesmo foi possivel encontrar uma solução relativamente simples para o problema adicionando-se ácido cítrico, ao próprio extrato orgânico, inibindo sua reação com a fenilfluorona.

Portanto, com relação às possíveis interferências, o método mostrou-se bastante eficiente, permitindo a determinação do molibdênio quando presente na solução original grande nümero de íons em teores elevados, inclusi ve daqueles ions que normalmente acompanham o molibdênio, como $\mathrm{Ti}(\mathrm{IV}), \operatorname{Zr}(\mathrm{IV}), \mathrm{Fe}(\mathrm{III}), \mathrm{V}(\mathrm{V}), \mathrm{Cr}(\mathrm{III}), \mathrm{Nb}(\mathrm{V}), \mathrm{Ta}(\mathrm{V})$ e $W(V I)$.

Relativamente ao método de Majundar e Savariar (46) que utiliza a mesma reação em meio aquoso, cabe ressaltar que o desenvolvimento da reação em meio orgânico permitiu alcançar o dobro da sensibilidade, facilitou o de senvolvimento da cor sem exigir controle de temperatura e 
de $\mathrm{pH}$ e também superou o problema dos íns que interferem naquele métođo.

A simplicidade da tēcnica e a possibilidade de se usarem amostras de pequeno volume são outros fatores que contribuem para tornar o mëtodo de fácil execução.

o estudo polarográfico, de caráter preliminar, abriu o caminho para investigações mais aprofundadas, levando a acreditar que condições bastante favoráveis poderão ser estabelecidas para o aproveitamento analítico. 


\section{1) APARELHAGEM}

As medidas espectrofotométricas foram executadas em espectrofotômetro Zeiss, modêlo PMQ-II, tendo-se empregado cubas de corex com rolhas esmerilhadas de $1 \mathrm{~cm}$ de caminho ōtico. Os espectros referentes à figura 4 foram determinados utilizando-se cubas de quartzo de $0,2 \mathrm{~cm}$ de caminho ōtico.

Os espectros referentes ao composto molibdênio-fenilfluorona em diferentes solventes - figuras 8 a 18 , foram determinados em espectrofotômetro registrador Beckman $D B-G$.

Os espectros de fluorência foram determinados em espectrofotômetro de fluorescência Perkin Elmer, mo delo MPF-2A.

O espectro de refletância foi determinado em um espectrofotômetro Zeiss, modelo PMQ-II acoplado com um acessōrio de reflexão modelo $\mathrm{RA}-3$.

O espectro eletrônico no visível foi determi nado em espectrofotômetro Cary, modelo 14 
As extrações foram feitas usando-se tubos de vidro, com rolhas de plástico (N8 13), cerca de $10 \mathrm{~cm}$ de comprimento e capacidade de aproximadamente $6 \mathrm{ml}$. A remoção da fase orgânica foi feita, sempre, com pipetas de extração do tipo descrito por carlton ${ }^{(74)}$.

Para a determinação do coeficiente de extração os tubos utilizados foram de fundo chato, de aproximadamente $15 \mathrm{~cm}$ de comprimento e iguais entre si, com rolhas esmerilhadas.

Nos ensaios qualitativos com sais de fosfônio utilizou-se microtubos de $6,5 \mathrm{~cm} \times 0,8 \mathrm{~cm}$ e para remover a fase orgânica usou-se pipetas de extração do tipo "conta-gotas". Estes ensaios foram executados da seguinte maneira:

Ao tubo de extração adicionou-se 1 gota de solução $200 \mu \mathrm{g} / \mathrm{ml}$ em molibdênio e 1 gota da solução do sal de fosfộ nio em solução aquosa 108 . Adicionou-se $0,4 \mathrm{ml}$ de ãcido cloridrico $(4 \mathrm{~N}, 6 \mathrm{~N}$ ou $9 \mathrm{~N}$, dependendo da prova) e 0,5 ml de solvente. Agitou-se e após centrifugação removeu-se a fase orgânica para outro tubo ao qual adicionou-se 2 gotas de so Iução do reagente (fenilfluorona em solução alcoōlica-sulfúrica). Para cada solvente acompanhou uma amostra não con tendo o fosfônio e os dados foram obtidos por comparação visual da cor entre as duas amostras após a adição do reagente. 
2) SOLVENTES E REAGENTES.

Solução do reagente (fenilfluorona).

A fenilfluorona utilizada em todo o trabalho fol de fabricação Merck.

A solução do reagente foi preparada da seguinte maneira: $0,0500 \mathrm{~g}$ de fenilfluorona foram dissolvidos a 70으, aproximadamente, em $150 \mathrm{ml}$ de älcool absoluto contendo $12,5 \mathrm{ml}$ de solução ãcido sulfúrico 1:6. Completou-se a seguir o volume, após resfriamento, a $250 \mathrm{ml}$ em balão vo lumétrico com álcool etílico. A solução assim preparada mostrou-se estāvel por vārios meses quando guardada ao abrigo da luz.

O acetato de n-butila empregado foi o produto comercial do laboratório Carlo Erba. O solvente foi pre viamente tratado a fim de eliminar os peróxidos. Para isso, fol agitado, em funil de separação, com solução saturada de sulfato de ferro(II) atē não haver mais alteração na cor da fase aquosa. Separado o solvente, foi posto a secar sobre sulfato de sódio anidro e depois destilado a 121 으. As destilações foram realizadas ao abrigo da luz, a fim de evitar a Influência desta na formação de peróxidos.

o álcool etílico utilizado na preparação da solução do reagente e nas subsequentes diluições foi tratạ 
do previamente para eliminar aldeído uma vez que este ataca a fenilfluorona. O tratamento consistiu em refluxar o álcool por duas horas aproximadamente, com hidróxido de sō dio e pó de zinco e em seguida destilá-lo.

3) SOLUÇÃO PADRÃO DE MOLIBDENIO.

Foi preparada uma solução concentrada conten do 5,0438g de molibdato de sódio bihidratado por litro. A solução foi padronizada por gravimetria com acetato de chumbo ${ }^{(94)}$. Esta solução contēm $2000 \mu \mathrm{g}$ em Mo/ml. As soluções usadas no decorrer do trabalho foram obtidas por diluições recentes da solução padrão.

4) SOLUÇÕES USADAS NO ESTUDO DAS INTERFERENCIAS.

De modo geral preparou-se soluções contendo $20 \mathrm{mg} / \mathrm{ml}$ do ín a ser estudado. No caso das interferências dos cátions usou-se nitratos ou sulfatos e no caso, dos ânious usou-se sais de sódio, potássio ou amônio. o bismuto(III), antimônio(III) e estanho(IV) foram preparados a partir dos cloretos pela dissolução em soluções ligeiramen te clorídricas. $\mathrm{O} \mathrm{V}(\mathrm{V})$ e $\circ \mathrm{Nb}(\mathrm{V})$ foram preparados a partir 
de vanadato de sódio $\left(\mathrm{NaVO}_{3}\right)$ e niobato de potássio $\left(\mathrm{KNbO}_{3}\right)$ pela dissolução dos sais em soluções ligeiramente alcalinas.

As soluções de titânio(IV) e tântalo(V) foram preparadas pela fusão de seus óxidos com pirossulfato de potãssio, dissolução da massa fundida com ãcido sulfúrí co concentrado e posterior diluição.

5) TRATAMENTO INICIAL DA AMOSTRA. ELIMINAÇÃO DE Ge (IV) , $\mathrm{C}_{2} \mathrm{O}_{4}^{-2}, \mathrm{MnO}_{4}^{-}$e $\mathrm{Cr}_{2} \mathrm{O}_{7}^{-2}$.

$\mathrm{Na}$ presença de $\mathrm{Ge}$ (IV), $\mathrm{MnO}_{4}^{-}$e $\mathrm{Cr}_{2} \mathrm{O}_{7}^{-2}$ procedeu-se a um aquecimento vigoroso, quase à secura da amostra, por tres vezes, com ácido clorídrico concentrado. 0 $\mathrm{Ge}$ (IV) foi eliminado na. forma de $\mathrm{GeCl}_{4}$ volátil e tanto o $\mathrm{MnO}_{4}^{-}$quanto $\circ \mathrm{Cr}_{2} \mathrm{O}_{7}^{-2}$ foram reduzido a $\mathrm{Cr}^{+3}$ e $\mathrm{Mn}^{+2}$ que não interferem na determinação do molibdênio.

Na presença de oxalato tratou-se a amostra com solução de $\mathrm{MnO}_{4}^{-}$em meio ácido e após eliminação total adicionou-se $\mathrm{HCl}$ concentrado para reduzir $\circ \mathrm{MnO}_{4}^{-}$a $\mathrm{Mn}^{+2}$.

Depois deste tratamento as amostram foram di luidas a $100 \mathrm{ml}$ e fez-se a determinação do Mo(VI) de acordo com o andamento já descrito anteriormente. Na tabela 31 reuniu-se os resultados obtidos. 
Determinação de Mo(VI) após eliminação de germânio e oxalato.

\begin{tabular}{|c|c|cc|}
\hline Ions presentes & Mo(VI) presente & Mo(VI) encontrado \\
$\mu \mathrm{g}$ & $\mu \mathrm{g}$ & \multicolumn{2}{|c|}{$\mu \mathrm{g}$} \\
\hline $1000 \mathrm{Ge}(\mathrm{IV})$ & 10,0 & 9,93 & 10,2 \\
$1000 \mathrm{C}_{2} \mathrm{O}_{4}^{2}$ & 10,0 & 10,0 & 10,3 \\
$1000 \mathrm{Ge}(\mathrm{IV})+1000 \mathrm{C}_{2} \mathrm{O}_{4}^{-2}$ & 10,0 & 10,1 & 9,85 \\
\hline
\end{tabular}

6) SAIS DE FOSFÔNIO

Os sais de fosfônio foram preparados segundo Michaelis Soden ${ }^{(95)}$ que sintetizou o iodeto de trifenil iso-butil-fosfônio a partir da trifenilfosfina e o iodeto de isobutila. Na preparação do brometo de trifenil n-butil fosfônio e coo brometo de trifenil iso-butil fosfônic, partiu-se dos haletos previamente destilados e fez-se a reação com a trifenil fosfina mantendo pequeno excesso do haleto. Aqueceu-se em banho maria por tres dias ao fim dos quais obteve-se para ambos os sais um sólido branco, solúvel em álcool. Os sais foram recristalizados em eter e secos a văcuo. Apresentaram os seguintes pontos de fusão:

$$
\begin{aligned}
& \text { brometo de n-butil fosfônio }-(242,5-244,5) \text { OC }^{-} \\
& \text {brometo de iso-butil fosfônio }-(206,0-208,0) \text { 으 }
\end{aligned}
$$


7) DESTRUIÇÃO DO COMPLEXO MOLIBDENIO-FENILFLUORONA

Foram pesadas tres amostras do composto em balanças sensiveis a centésimo de miligrama. Cada amostra foi tratada com $10 \mathrm{ml}$ de peridrol e 0,2g de hidróxido de sódio em banho maria atē completa destruição do complexo e a solução tornar-se perfeltamente límpida, incolor e livre do excesso de āgua oxigenada. As soluções obtidas foram lí geiramente aciduladas com ácido clorídrico e o volume leva do a $100 \mathrm{ml}$ com ãgua destilada. Destas soluções foram pipe tas alíquotas de $0,50 \mathrm{ml}$ para os tubos de extração e feltas as determinações.

8) DETALHES REFERENTES AOS ESTUDOS POLAROGRAFICOS

Os polarogramas foram obtidos com a utilização de um polarógrafo "Sargent" modelo xV - automático.

Mantiveram-se constantes, em todas as determinações, as características do eletrodo gotejante de mercúrio, a altura da coluna de mercūrio e o tempo de gotejamento. A temperatura manteve-se constante em 25,0 $\pm 0,5$ 으. 
A célula polarogrāfica utilizada foi semeIhante a descrita por Pecsos e Juvet (103) do tipo "H". O eletrodo de referência constituiu-se em mercúrio metālico em contacto com pasta de calomelano, cloreto de sódio e so lução saturada do sal.

Utilizou-se solução saturada e sulfato de sō dio como ponte salina.

Todas as amostras polarografadas foram prepa radas pela diluição de $1,0 \mathrm{ml}$ da solução contendo a espécie eletroativa a $10,0 \mathrm{ml}$ com a solução do eletrólito suporte preparado previamente.

O eletrólito suporte utilizado foi uma solução $0,30 \mathrm{~N}$ em ācido nítrico saturada com nitrato de potāssio (3M). 
O estudo da extratibilidade do Molibdênio(VI) de soluções cloríaricas, com grande número de solventes, permitiu encontrar condições de extração quantitativa que foram utilizadas na elaboração de um mētodo espectrofotomé trico de determinação do elemento.

o método baseia-se no desenvolvimento da rea ção, em meio orgânico, do molibdênio(VI) com o reagente co lorimētrico fenilfluorona $(2,3,7$-trihidroxi-9-fenil-6-fluo rona), após sua extração de solução $6 \mathrm{~N}$ em ácido clorídrico com acetato de n-butila. O estudo da influência de vários fatores sobre a reação permitiu chegar às melhores condições de reprodutividade nas determinações.

A extração do elemento nas condições estabelecidas tornou o reagente seletivo para o molibdênio com relação à maior parte dos elementos que normalmente $\circ$ acom panham.

Devido à importância tanto da separação molibdênio-tungstênio, quanto da determinação de um na presença do outro, desenvolveu-se um estudo sistemático, dentro do campo da extração com solventes, em que vārios fato res foram examinados. Em decorrência, foi possível resol- 
ver satisfatoriamente $\circ$ problema da interferência do tungs tênio(VI) no mētodo colorimētrico, mediante a inibição de sua reação com a fenilfluorona, no extrato orgânico, pela presença do ācido cítrico.

As medidas colorimētricas das soluções, feitas em $506 \mathrm{~nm}$, permitem determinar de 0,1 a $2,5 \mu \mathrm{g}$ de Mo(VI)/ml na diluição final, sendo que a faixa mais apropriada para as determinações está compreendida entre 0,45 a $1,8 \mu \mathrm{g}$ de $\mathrm{Mo}(\mathrm{VI}) / \mathrm{ml}$.

O método, bastante sensível, permite a deter minação em materials contendo teores muito baixos do elemen to, mediante o emprego de uma técnica simples e rápida.

Alguns estudos feitos no campo da polarográfia, em que se procurou utilizar as vantagens da extração seletiva do molibdênio(VI), abriram um novo caminho para o aproveitamento analítico.

o composto molibdènio(VI)-fenilfluorona foi preparado e apresentaram-se algumas de suas características, tanto em soluções, 'quanto no estado sólido. 


\section{$\underline{X I-B I B L I O G R A F I A}$}

1- A.I. Busev e T.V. Rodionova J. Anal. Chem 3, 297 (1971).

2- E.B. Sandell Colorimetric determination of traces of metals" Interscience Publishers Ltd., London, 28 ed. 1950.

3- Loren C. Hurd e Harry O. Allen -

Ind. Eng. Chem. Anal. Ed. 7,396 (1935).

4- C.F. Hiskey e V.W. Meloche -

J. Am. Chem. Soc. 62, 1965 (1940).

5- A.K. Babko -

J. Gen. Chem. (U.S.S.R.), 17, 642 (1947); C.A. 42,476 (1947).

6- F.S. Grimaldi e R.C. Wells -

Ind. Eng. Chem. Anal. Ed. 15, 315 (1943).

7- Mitchell Kapron e Paul L. Hehman -

Ind. Eng. Chem. Anal. Ed. 17, 573 (1945).

8- A.I. Lazarev -

Zavodskaya Lab. $\underline{24}, 798$ (1958); C.A. $\underline{55}, 237 \mathrm{~b}$ (1961).

9- L.I. Lebedeva e V.K. Potrokhov -

Metody Kolichestv. Opred. Elementov, Leningr. Gos.

Univ. 55 (1964); C.A. 63, 4945b (1965).

10- D.D. Perrin -

New. Zealand J. Sci. Tech., 28A, 183 (1946); C.A. 40, $7268^{5}$ (1946).

11- J.0. Hibbitz e R.T. Williams -

Anal. Chim. Acta 26, 362 (1962). 
12- Orland. W. Kolling -

Anal. Chem. NO3, 37, 436 (1965).

13- Gerald A. Bauer -

Anal. Chem. Nol, 37, 155 (1965).

14- W.O. Robinson -

So11 Sci., 66, 317 (1948); C.A. 吕, 8883i (1948).

15- S.C. Dhara e S.M. Khopkkar -

Indian J. Chem. 5(1), 12 (1967); C.A. $6739857 t$ (1967).

16- Takaoshi Yoshimori -

Bunseki Kagaku 9, 689 (1960); C.A. 55, 18442a (1961).

17- Ping Y. Peng e E.B. Sandell -

Anal. Chim. Acta 29(4), 325 (1963).

18- J.P.MC. Kaverney e H.Freiser -

Anal. Chem. 29, 290 (1957).

19- J.H. Hamence -

Analyst 65, 152 (1940).

20- Bickford W.S. Jones e J.S. Keene -

J. Am. Pharm. Assoc. 37, 255 (1948).

21- C. Piper e R.S. Beckwith -

J. Soc. Chem. Ind. 67, 374 (1948).

22- S.H. Allen e M.B. Hamilton -

Anal. Chim. Acta I, 483 (1952).

23- P.G. Jeffery -

Analyst, 81, 104 (1956).

24- Everett W. Hobart e E.P. Hurley -

Anal. Chim. Acta 27, 144 (1962). 


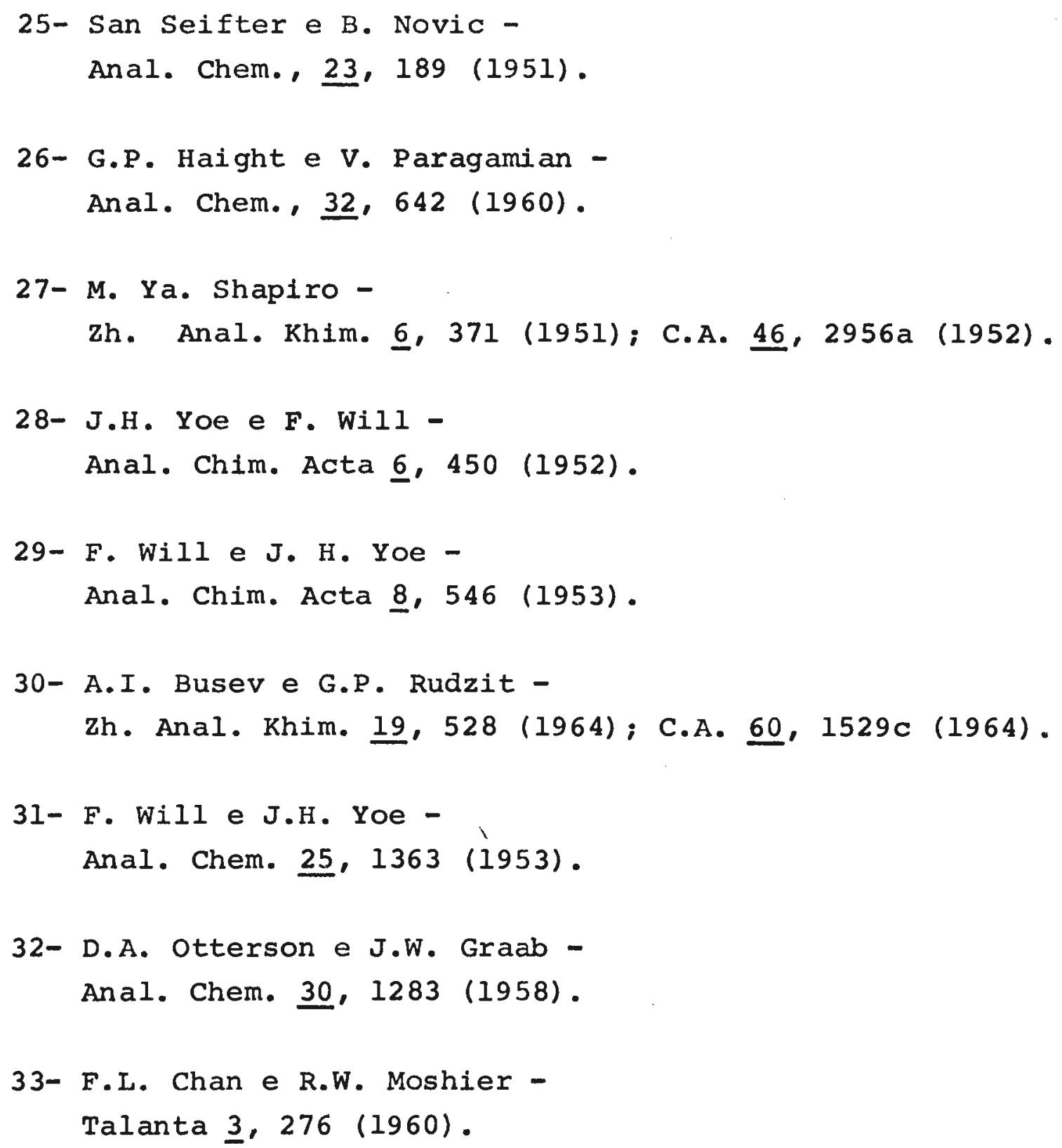


38- G.R. Waterbury e C.E. Bricker Anal. Chem. 29, 129 (1957).

39- J. Gillis, A. Claeys e J. Hoste Anal. Chim. Acta 1, 421 (1947).

40- J. Gillis, A. Claeys e J. Hoste Anal. Chim. Acta I, 302 (1947).

41- H. J. Cluley -

Analyst 76, 523 (1951).

42- C.L. Luke -

Anal. Chem., 28, 1276 (1956).

43- F.G. Zharowskii e Pilipenko -

Zavodskaya Lab. 23, 1407 (1957); C.A. 54, 8465a (1960).

44- Masayoshi Ishibashi -

Bunseki Kagaku ㄱ, 473 (1958); C.A. 프, 16283b (1960).

45- Hirotoshi Sano -

Bunseki Kagaku I, 235 (1958); C.A. 54, 3079b (1960).

46- A.K. Majundar e C.P. Savariar -

Anal. Chim. Acta. 21, 584 (1959).

47- R.L. Bennett e H.A. Smitt -

Anal. Chem. (8) 31, 1441 (1959).

48- A.K. Majundar e C.P. Savariar -

Anal. Chim. Acta, 22, 158 (1960).

49- B.M. Lipshitz e K. Smirnova -

Zavodskaya Lab. 26, 273 (1960).

50- W.A. Shneider e E.B. Sandell -

Mickrochimica Acta 263 (1954). 
51- I.M. Landenbauer, O. Slama e F. Hecht Mickrockimica Acta 118 (1955).

52- C.L. Luke e M.E. Campbell Anal. Chem, 28, 1273 (1956).

53- K. Kimura, K. Saito e M. Osada Bul1. Chem. Soc. Japan 29, 635 (1956).

54- Hirotosh1 Sano Bull. Chem. Soc. Japan (8) 31, 974 (1958).

55- M.B. Shustova e V.A. Nazarenko Zh. Anal. Khim. 18 (8), 964, (1963); C.A. 5914571 (1963).

56- P. Senise e L. Sant'Agostino Mickrockimica Acta 572 (1959).

57- L. Sant'Agostino "Determinação micro-analítica de germanio" - Tese de doutoramento F.F.C.L.U.S.P. (1959).

58- G.H. Morrison e H. Freiser "Solvent Extraction in Analytical Chenistry" John Wiley \& Sons, Inc.; New York, 1957, pg 129.

59- J.J. Lagowski -

"The Chemistry of Non- Aqueous Solvents" Vol I, Sect IV.B. 2 pg 203.

60- I. Nelidow e R.M. Diamond -

J. Phys. Chem. 59, 710 (1955).

61- A. I. Busev, V.A. Frolkina e M. Koroleva J. Anal. Chem (U.S.S.R.) 24, 103 (1969. 
62- V.K. Arend e H. Specker -

Z. Anorg. Allgem. Chem. 333, 18 (1964).

63- A. Ringbom -

Z. Anal. Chem., 115, 385 (1939).

64- R. Boch e M. Herrmann -

Z. Anorg. Allgem. Chem., 284, 288 (1956).

65- A.I. Vogel -

"Química Analítica Cualitativa" - Editorial Kapelusz

S.A. B.Aires 5á ed. 1969, pag 473 .

66- W.J. Blaedel e V.W. Meloche -

"Elementary Quantitative Analysis: Teory and Practice",

Harper \& Pow, Publishess, New York, 1963, 2a ed. p.622

67- George H. Morrison e H. Freiser Anal. Chem. 34, 64R (1962).

68- George H. Morrison e H. Freiser Anal. Chem. 36, 93R (1964).

69- George H. Morrison e H. Freiser Anal. Chem. 38, 131R (1966).

70- George H. Morrison e H. Freiser Anal. Chem. 40, 522R (1968).

71- A.I. Busev e V.A. Frolkina Khim. 20(4), 69 (1965); C.A. 63, 17215e (1965).

72- A.I. Busev e V.A. Fŕolkina Khim. 20(2), 72 (1965); C.A. 63, 1252a (1965).

73- Golinsky Marek -

Przenysl Chem. 44 (b), 312 (1965); C.A. $63,12393 \mathrm{e}$ (1965). 


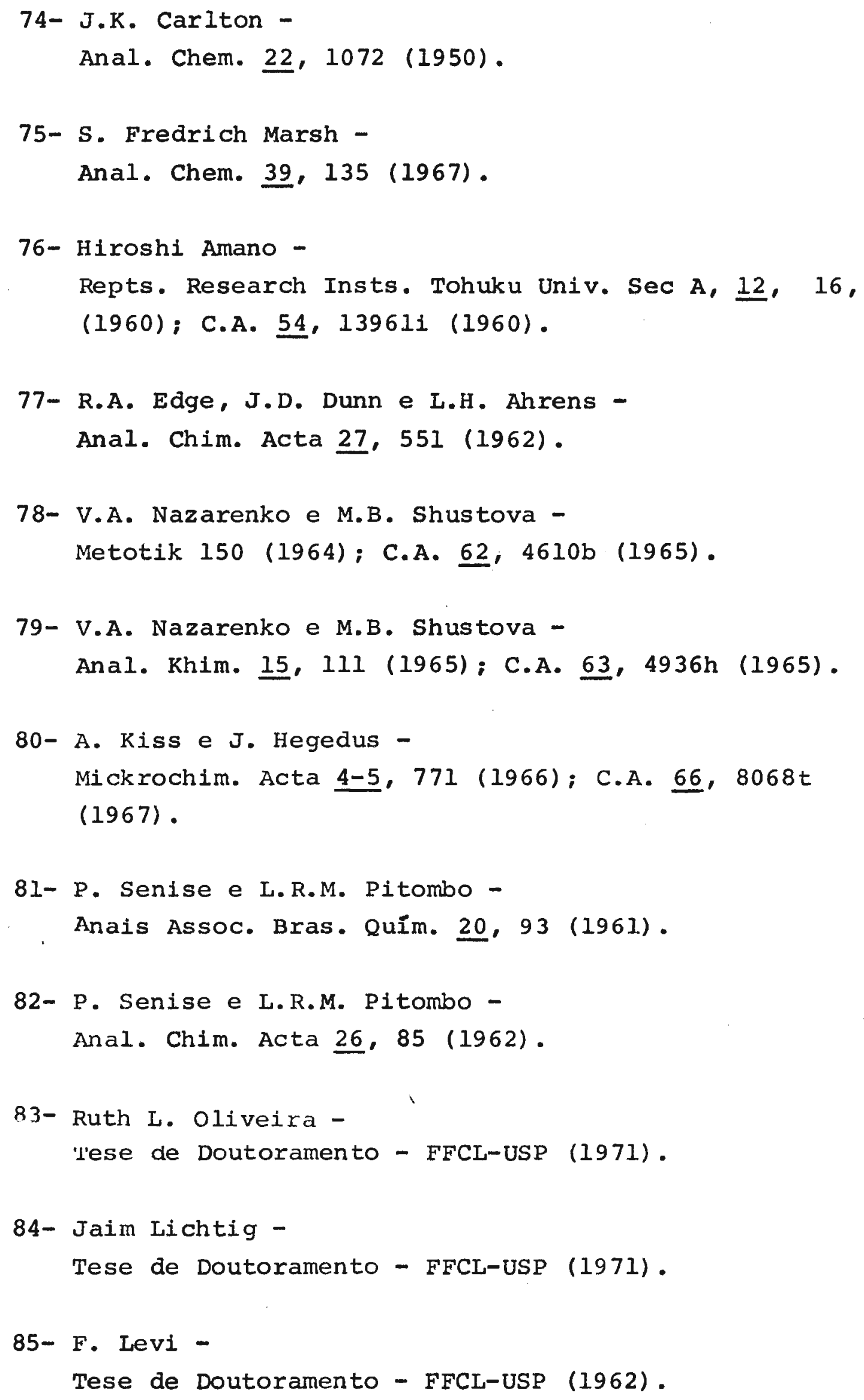




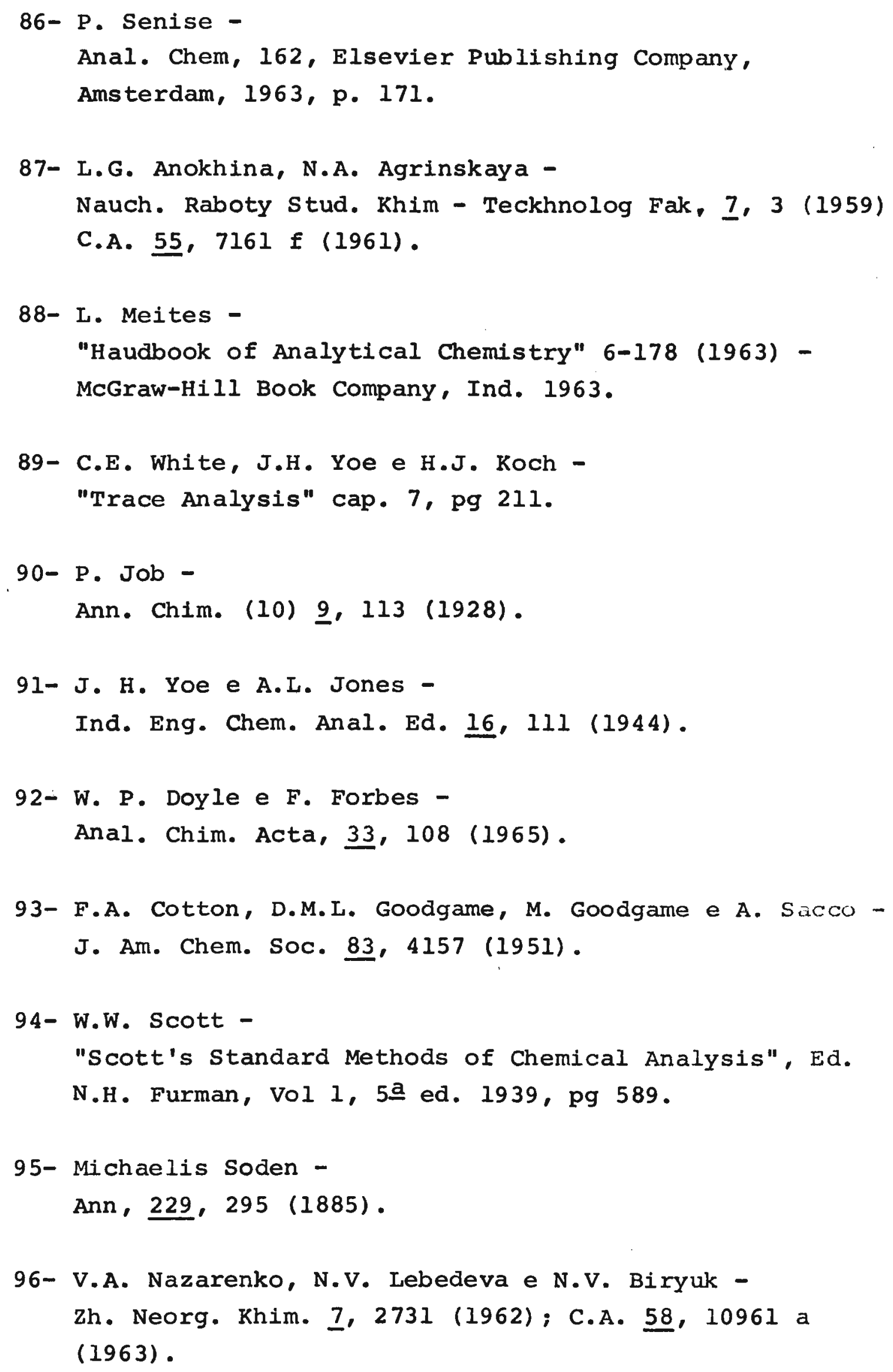




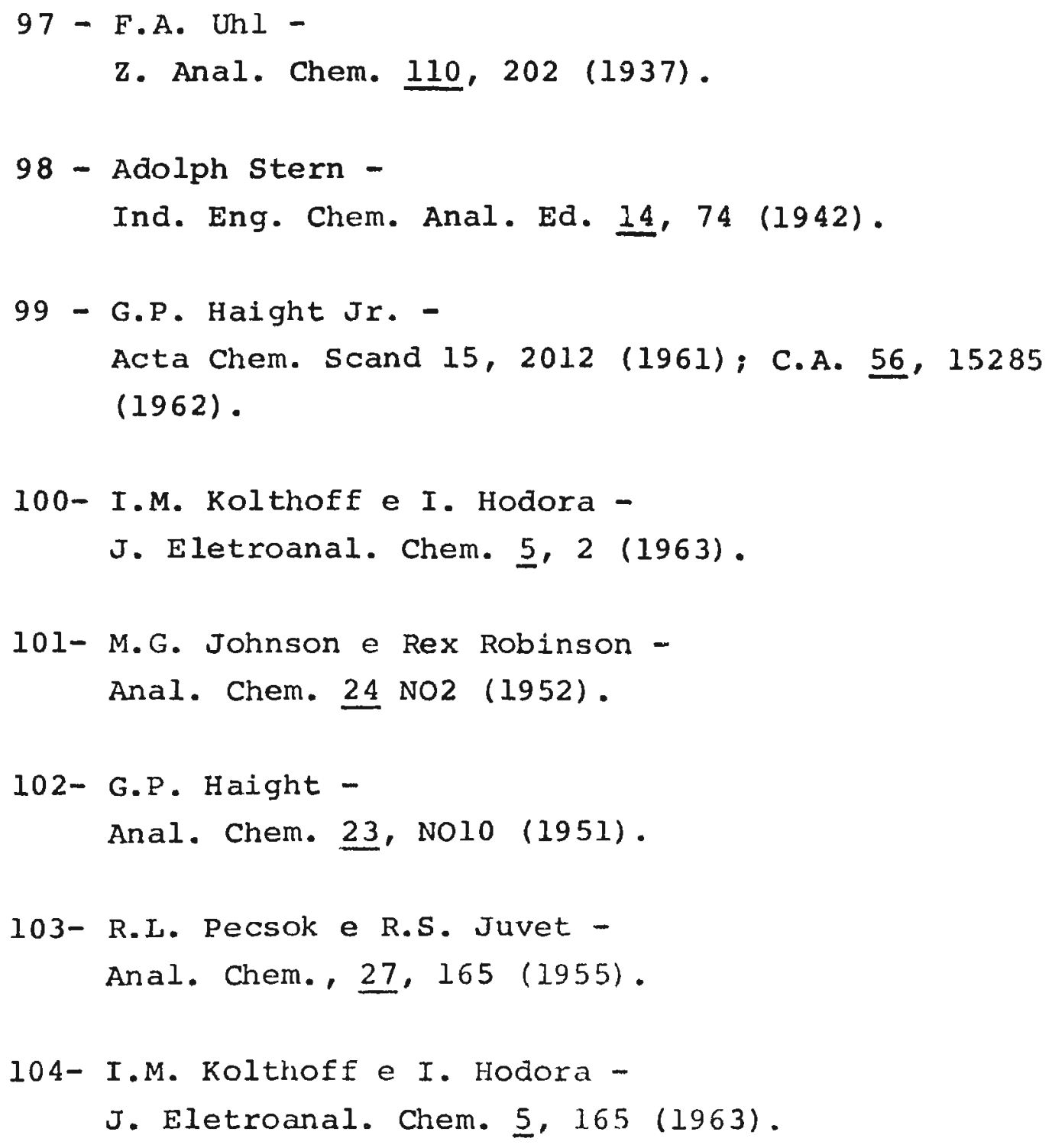

